\title{
HEINONLINE
}

Citation: 87 S. Cal. L. Rev. 1359 2013-2014

Content downloaded/printed from

HeinOnline (http://heinonline.org)

Wed May 6 12:39:35 2015

-- Your use of this HeinOnline PDF indicates your acceptance of HeinOnline's Terms and Conditions of the license agreement available at http://heinonline.org/HOL/License

-- The search text of this PDF is generated from uncorrected OCR text.

-- To obtain permission to use this article beyond the scope of your HeinOnline license, please use:

https://www.copyright.com/ccc/basicSearch.do?

\&operation $=$ go\&search Type $=0$

\&lastSearch $=$ simple\&all $=$ on\&titleOrStdNo $=0038-3910$

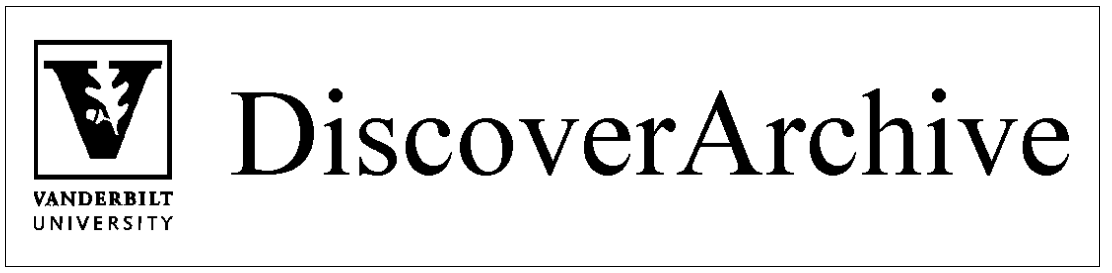

Retrieved from DiscoverArchive,

Vanderbilt University's Institutional Repository

This work was originally published as Paul H. Edelman, Randall

S. Thomas, and Robert B. Thompson. Shareholder Voting in an

Age of Intermediary Capitalism - 87 Southern California Law

Review 1359 (2015). 


\title{
ARTICLES
}

\section{SHAREHOLDER VOTING IN AN AGE OF INTERMEDIARY CAPITALISM}

\author{
PaUl H. EDELMaN ${ }^{*}$ \\ RANDALL S. THOMAS ${ }^{\dagger}$ \\ ROBERT B. THOMPSON ${ }^{\ddagger}$
}

INTRODUCTION

Shareholder voting, once given up for dead as "a vestige or ritual of little practical importance," has come roaring back as a key part of American corporate governance. Where once voting was limited to uncontested annual election of directors, it is now common to see short

* Professor of Law and Professor of Mathematics, Vanderbilt University.

$\dagger$ John S. Beasley II Professor of Law and Business, Vanderbilt University.

$\ddagger$ Peter P. Weidenbruch Jr. Professor of Business Law, Georgetown University.

We would like to thank Professors James Cox, Quinn Curtis, Paul Davies, Fabrizio Ferri, Jill Fisch, Jesse Fried, Martin Gelter, George Geis, Henry Hu, Michael Klausner, Colin Mayer, Brett McDonnell, Frank Partnoy, Edward Rock, Harwell Wells and the participants of the Vanderbilt Corporate Voting Workshop, for their helpful comments on this Article. We would also like to thank Brendan Sullivan, Brittany Heyd, and Kyuwang Jeong from the Georgetown University Law Center Class of 2012, 2013, and 2014 and Justin Gunter from the Vanderbilt Law School Class of 2013, for their research. All remaining errors are our own.

1. Blasius Indus., Inc. v. Atlas Corp., 564 A.2d 651, 659 (Del. Ch. 1988). Bayless Manning in a classic article stated:

It is commonplace to observe that the modern shareholder ... does not think of himself or act

like an "owner." He hires his capital out to the [corporate] managers and they run it for him; how they do it is their business, not his, and he always votes 'yes' on the proxy.

Bayless Manning, The Shareholder's Appraisal Remedy: An Essay for Frank Coker, 72 YALE L.J. 223, 261 (1962). 
slate proxy contests, ${ }^{2}$ board declassification proposals, ${ }^{3}$ and "Say on Pay" votes ${ }^{4}$ occurring at public companies. The surge in the importance of shareholder voting has caused increased conflict between shareholders and directors, a tension well illustrated in recent voting battles. For example, Carl Icahn's hedge fund opposed Michael Dell's 2013 bid to take Dell, Inc. private, claiming that the price offered was too low. ${ }^{5}$ After a prolonged election battle, a change in the election rules, and a small increase in the deal price, shareholders ultimately voted for the deal. ${ }^{6}$ In a similar vein, a 2012 Say on Pay vote by Citigroup shareholders against chief executive officer Vikram Pandit's $\$ 15$ million pay package led to his departure and substantive changes to executive compensation, after which more than 90 percent of the firm's shareholders approved its proposed executive pay scheme. ${ }^{7}$ Yet, despite the obvious importance of shareholder voting, none of the existing corporate law theories coherently justify it. ${ }^{8}$

2. Short slate contests arise when dissident shareholders, often hedge funds, seek to gain a minority of seats on the board of directors. Steven M. Davidoff, Revisiting the Proxy Contest, N.Y. TIMES (Mar. 2, 2009 9:30 AM), http://dealbook.nytimes.com/2009/03/02/revisiting-the-proxy-contest/. Oftentimes companies will agree to such representation so long as key management directors get to keep their seats. Joann S. Lublin \& Drew FitzGerald, Activists Spur Horse Trading For Seats on Corporate Boards, WALL ST. J. (Aug. 20, 2013, 8:00 PM), http://online.wsj.com/news/ articles/SB10001424127887323423804579023262356923606.

3. The Shareholder Rights Project at Harvard Law School has been actively supporting shareholders making these proposals. 98 Companies Declassified During 2012-2014, SHAREHOLDER RIGHTS PROJECT, http://srp.law.harvard.edu/declassifications.shtml (last updated June 30, 2014).

4. See generally Randall S. Thomas, Alan R. Palmiter \& James F. Cotter, Dodd-Frank's Say on Pay: Will It Lead to a Greater Role for Shareholders in Corporate Governance? 97 CORNELL L. REV. 1213 (2012) (explaining the origins of shareholder advisory votes on corporate executive compensation at public companies and analyzing its likely effects). See also infra text accompanying note 39.

5. Arik Hesseldahl, Ichan Makes Another Offer for Dell as Shareholders Shrug, WaLL ST. J.: ALLTHINGSD, (July 1, 2013, 3:30 PM), http://allthingsd.com/20130701/icahn-makes-another-offer-fordell-as-shareholders-shrug/REYWORDS=Dell\#. See also, Theo Francis, Dell's Buyout Fate Still Hinges Mostly on Icahn, N.Y. TIMES (July 22, 2013, 3:41 PM), http://dealbook.nytimes.com/ 2013/07/22/dells-buyout-fate-still-hinges-mostly-on-icahn/ (discussing Carl Icahn's voting power in opposing the proposed Dell buyout).

6. Ben Fox Rubin \& David Benoit, Dell Shareholders Approve Buyout, WaLl ST. J. (Sept. 12, 2013, 10:38 AM), http://blogs.wsj.com/moneybeat/2013/09/12/dell-shareholders-approve-buyout/. See also Michael J. de la Merced, Dell Buyout Bid in Peril as Voting Rule Remains, N.Y. TIMES (July 31, 2013, 9:05 AM), http://dealbook.nytimes.com/2013/07/31/dell-offers-to-move-vote-on-takeover-butrefuses-to-bend-on-voting-rules/ (describing the Dell buyout and Dell's attempts to alter the voting rules).

7. Jessica Silver-Greenberg \& Nelson D. Schwartz, Citigroup's Chief Rebuffed on Pay by Shareholders, N.Y. TIMES (Apr. 17, 2012, 1:28 PM), http://dealbook.nytimes.com/2012/04/17/ citigroup-shareholders-reject-executive-pay-plan/; Tom Braithwaite, Dan McCrum \& Kara Scannell, Citigroup Sees Off Shareholder Revolt on Executive Pay, FIN. TIMES (Apr. 24, 2013, 5:29 PM), http://www.ft.com/intl/cms/s/0/ef667544-ace 1-1 l e2-b27f-00144feabdc0.html\#axzz2dOEJ6hvL.

8. For a critique of these theories, see infra Part I. 
Traditional theories about shareholder voting, rooted in concepts of residual ownership and a principal-agent relationship, do not easily fit within the longstanding legal structure of corporate law that generally cabins the shareholder role in corporate governance. Nor do these theories reflect recent fundamental changes as to who shareholders are and their incentives to vote (or not to vote). Most shares today are owned by intermediaries that usually hold other people's money within retirement plans, and that follow business plans that give them little reason to vote those shares or result in conflicts that may distort that vote. ${ }^{9}$ Yet three key developments have countered that reality and opened the way for shareholder voting's new prominence. First, government regulations now require many institutions to vote their stock in the best interests of their beneficiaries. ${ }^{10}$ Second, subsequent market innovations led to the birth of proxy advisory firms, including Institutional Shareholder Services ("ISS"), which help address the costs of voting and the collective action problems inherent in coordinated institutional shareholder action. ${ }^{11}$ And third, building on these developments, hedge funds have aggressively intervened in corporate governance at firms seen as undervalued ${ }^{12}$ by making frequent use of the ballot box to pressure targeted firms to create shareholder value, thereby giving institutional shareholders a good reason to care about voting. ${ }^{13}$

9. Institutions now own 70 percent or more of the shares in America's largest corporations, a dramatic change from a generation ago. CONFERENCE BD., THE 2010 INSTITUTIONAL INVESTOR REPORT: TRENDS IN ASSET ALLOCATION AND PORTFOLIO COMPOSITION 22 tbl.10, 27 tbl.13 (2011).

10. See infra Part II.A.3.

11. ISS is the world's leading provider of proxy advisory services to institutional investors. Governance Advisory Services, ISS, http://www.issgovernance.com/governance-solutions/governanceadvisory-services/ (last visited Aug. 17, 2014). For information regarding the development of proxy advisory firms, see infra Part II.A.4.

Numerous studies have found that voting recommendations made by ISS carry great weight, swinging 10-30 percent of the vote in many situations. See, e.g., Yonca Ertimur, Fabrizio Ferri \& David Oesch, Shareholder Votes and Proxy Advisors: Evidence from Say on Pay, 51 J. ACCT. RES. 951, 953 (2013) ("Negative ISS ... recommendations are associated with 24.7 [percent] ... more votes against the compensation plan."). See also infra Part II.A.4 \& Part III.B.3.b.

12. Alon Brav et al., Hedge Fund Activism, Corporate Governance, and Firm Performance, $63 \mathrm{~J}$. FIN. 1729, 1730 (2008) ("Hedge fund activists tend to target companies that are typically 'value' firms, with low market value relative to book value, although they are profitable with sound operating cash flows and return on assets."). See also Michael J. de la Merced \& Julie Creswell, With Huge War Chests, Activist Investors Tackle Big Companies, N.Y. TIMES (Aug. 30, 2013, 9:01 PM), http://dealbook.nytimes.com/2013/08/30/with-huge-war-chests-activist-investors-tackle-big-companies/ (discussing hedge fund activism in major corporations such as Microsoft and Procter \& Gamble).

13. See Ronald J. Gilson \& Jeffrey N. Gordon, The Agency Costs of Agency Capitalism: Activist Investors and The Revaluation of Governance Rights, 113 COLUM. L. REV. 863, 897 (2013) ("Rather [activist investors] are governance entrepreneurs, arbitraging governance rights that become more valuable through their activity monitoring companies to identify strategic opportunities and then 
But there is more to the corporate franchise than hedge fund-inspired voting. Say on Pay proposals, Rule 14a-8 corporate governance proposals, and majority vote requirements for the election of directors are all important, recurrent topics involving shareholder votes where the vote's immediate impact on stock price may be positive ${ }^{14}$ but insufficient to lead to hedge fund intervention, or which may affect only the long-term value of the corporation. ${ }^{15}$

The newly invigorated shareholder voting is not without its critics though. Corporate management has voiced fears about the increase in shareholders' voting power, ${ }^{16}$ as well as about proxy advisory firms' perceived conflicts of interest. ${ }^{17}$ The Securities and Exchange Commission

presenting them to institutional investors for their approval-through a proxy fight, should the portfolio company resist the proposal. By giving the institutions this choice, the activists increase the value of governance rights; the institutions' exercise of governance rights then becomes the mechanism for creating value for beneficial owners."). See also infra Part III.A.

14. For evidence that some corporate votes have a positive impact on firm value, see J. Harold Mulherin \& Annette B. Poulsen, Proxy Contests and Corporate Change: Implications for Shareholder Wealth, 47 J. FIN. ECON. 279, 292-93 (1998) (finding that for proxy contests for elections of directors, there is a statistically significant cumulative abnormal return of 8.04 percent twenty days before the contest announcement until five days afterwards); Vincente Cuñat, Mireia Giné \& Maria Guadalupe, The Vote Is Cast: The Effect of Corporate Governance on Shareholder Value, 67 J. FIN. 1943, 1954 (2012) [hereinafter Cunat et al., The Vote is Cast] (finding that in close votes, the passage of shareholder corporate governance proposals increases firm value); Vincente Cuñat, Mireia Giné, \& Maria Guadalupe, Say Pays! Shareholder Voice and Firm Performance 4, 6, 9 (Eur. Corporate Governance Inst., Fin. Working Paper No. 373/2013, 2013) [hereinafter Cuñat et al,, Say Pays/], available at http://ssm.com/abstract=2240410 (proposing that the implementation of Say on Pay in different countries around the world has increased firm value). See infra Part III.B.

15. See infra Part III. For purposes of this Article, we accept the claim that there can be divergences between the value of a corporation's stock price and its "long-run" value. See Martin Lipton, Deconstructing American Business II, BRIEFLY .. PERSP. ON LEGIS., REG. \& LiTIG., Dec. 2006, at 1, 1 (claiming that "[p]ressure on boards from activist investors to manage for short-term share price performance rather than long-term value creation" is a problem for American businesses in the future). We note that there is an ongoing debate over whether there are differences between long-term value and short-term value, and if so, the implications for corporate law. Compare Mark J. Roe, Corporate Short-Termism-In the Boardroom and in the Courtroom, 68 BUS. LAW. 977, 977-78 (2013) (finding minor support for the view that corporations' short-term perspectives influence corporate law), and Lucian A. Bebchuk, The Myth That Insulating Boards Serves Long-Term Value, 113 CoLuM. L. REV. 1637, 1637 (2013) (arguing that board insulation from shareholder pressure creates long-term costs), with Leo E. Strine, Jr., Can We Do Better By Ordinary Investors: A Pragmatic Reaction to the Dueling Ideological Mythologists of Corporate Law 114 CoLUM. L. REV. 449, 449 (2014) (specifically rejecting Professor Bebchuk's argument), and Martin Lipton, The Bebchuk Syllogism, HaRV. L. SCH. F. ON CORP. GOVERNANCE \& FIN. REG. (Aug. 26, 2013), http://www.wlrk.com/webdocs/wlrknew/ AttomeyPubs/WLRK.22753.13.pdf 1, 2 (questioning Professor Bebchuk's methodology and conclusion that short-term shareholder activism does not affect the long-term value of a corporation).

16. Lipton, Deconstructing American Business II, supra note 15, at 1-5 (discussing problems stemming from the shift from "director-centric governance" to "shareholder centric governance").

17. ROBYN BEW \& RICHARD FIELDS, TAPESTRY NETWORKS, INC., VOTING DECISIONS AT U.S. MUTUAL FUNDS: HOW INVESTORS REALLY USE PROXY ADVISORS 6-7 (2012) ("ISS' practices such as 
("SEC") has asked for public comments on the possible undue influence of proxy advisory firms on shareholder voting. ${ }^{18}$ Even institutional investors have varying views on the topic. ${ }^{19}$ Can we trust the vote to today's intermediaries and those who advise them?

Our Article proceeds as follows. Part I develops our theory of shareholder voting. We argue that shareholders (and only shareholders) have been given the right to vote because they are the only corporate stakeholders whose return on their investment is tied directly to the company's stock price; if stock price is positively correlated with the residual value of the firm, shareholders will want to maximize the firm's residual value and vote accordingly. Thus, shareholder voting should lead to value-maximizing decisions for the firm as a whole.

But that does not mean that shareholders should vote for everything. Economic theory and accepted principles of corporate law tell us that corporate officers exercise day-to-day managerial power at the public firm, with boards of directors having broad monitoring authority over them. In this framework, shareholder voting is explained by its comparative value as a monitor. We would expect a shareholder vote to play a supplemental monitoring role if the issue being decided affects the company's stock price, or long-term value, and if the shareholder vote is likely to be superior, or complementary, to monitoring by the board or the market. This is particularly likely when officers or directors of the company suffer from a conflict of interest, or may otherwise be seeking private benefits at the expense of the firm. Thus shareholder voting can play a negative role as a monitoring device by helping stop value-decreasing transactions. ${ }^{20}$

providing voting recommendations while also offering issuers services designed to suggest whether a particular management proposal will meet with investors' approval have resulted in conflict-of-interest charges.").

18. Concept Release on the U.S. Proxy System, Exchange Act Release No. 34-62495, 17 C.F.R. $\S \S 240,270,274,275$ (July 14, 2010) [hereinafter U.S. Proxy System Concept Release], available at http://www.sec.gov/rules/concept/2010/34-62495.pdf. The SEC held a Roundtable on December 23, 2013 regarding this topic. Proxy Advisory Services Roundtable, U.S. SEC. \& EXCHANGE COMMISSION, http://www.sec.gov/spotlight/proxy-advisory-services.shtml (last visited Aug. 17, 2014).

19. Comment Letter from Council of Institutional Investors to Elizabeth M. Murphy, Sec'y, U.S. Sec. \& Exch. Comm'n, on Concept Release on the U.S. Proxy System in Release No. 34-62495, at 5-7 (Oct. 14, 2010) [hereinafter Comment Letter from Council of Institutional Investors], available at http://www.sec.gov/comments/s7-14-10/s71410-80.pdf.

20. We note recent empirical evidence that shows mandatory shareholder voting on corporate acquisitions increases firm value by stopping bad deals. Marco Becht, Andrea Polo \& Stefano Rossi, Does Mandatory Shareholder Voting Prevent Bad Acquisitions? 31-32 (Eur. Corporate Governance Inst., Fin. Working Paper No. 442/2014, 2014), available at http://papers.ssm.com/sol3/papers.cfm? abstract_id=2443792. 
But monitoring is not the only theoretical justification for shareholder voting. We posit two additional theories that provide positive reasons for corporate voting because it enhances decisionmaking beyond monitoring. Shareholder voting can provide: (1) a superior information aggregation device for private information held by shareholders when there is uncertainty about the correct decision, ${ }^{21}$ and (2) an efficient mechanism for aggregating heterogeneous preferences when the decision differentially affects shareholders. ${ }^{22}$

In Part II we explore whether contemporary shareholders have the characteristics that permit them to play the roles our theory contemplates. In particular, we examine the business plan that gives today's intermediaries reasons not to vote or conflicts that can distort their vote. Similar attention is given to the regulatory and market changes that have grown up in response to this reality: government-required voting by intermediaries; proxy advisory firms to let this voting occur more efficiently; and hedge fund strategies to make voting pay, for themselves and for other intermediaries such as mutual funds and pension funds.

In Part III, we use our theory to illuminate when shareholder voting is justified. In Part III.A, we focus on the role of corporate voting where the issue is a high-dollar, "big ticket" decision. We use hedge fund activism as an example of this scenario and show how it fits with each of the prongs of our voting theory. ${ }^{23}$ Here we see voting performing the monitoring role anticipated by our theory, but there is also an important role for aggregating heterogeneous preferences among shareholders as institutional funds decide whether to follow hedge fund initiatives. Part III.B makes the less obvious case for shareholder voting where hedge funds drop out of the equationon decisions that have a smaller effect on stock prices or the company's long-term value, such as Say on Pay, majority voting proposals, and board

21. Our information aggregation theory can be illustrated by a target company shareholder vote on a merger offer where there is uncertainty about whether the price offered in the transaction is sufficient. A shareholder vote on the merger is more likely to lead to the correct decision than solely a vote of the board of directors, even if the board is not conflicted, because the increase in the number of informed voters is more likely to lead to the correct decision. This result follows from the Condorcet Jury Theorem. Robert B. Thompson \& Paul H. Edelman, Corporate Voting, 62 VAND. L. REV. 129, 132 n.5, 149-50 (2009). See infra Part I.B.

22. An example where this theory comes into play arises when a board needs to choose between issuing a dividend and using the same funds to make a strategic acquisition. Different shareholders may have different preferences about these two outcomes because of their tax status, their degree of risk aversion, or their time horizons. A shareholder vote will aggregate the shareholders' preferences to decide the issue.

23. See Gilson \& Gordon, supra note 13 , at $897-99$, for an analysis of hedge funds as leaders of institutional investor activism. 
declassification proposals. It focuses on Say on Pay, finding that there is substantial evidence that these votes increase firm value and, potentially, long-term value.

In sum, this Article presents a positive theory of corporate voting as it exists today. In doing so, it directly addresses the vast shifts in stock ownership that have created intermediary capitalism and the important role of government regulations and market participants in making corporate voting effective. At the same time, it preserves for corporate management the lion's share of corporate decisionmaking, subject to active shareholder monitoring using corporate voting in conflict situations that affect stock price.

We begin by providing a brief overview of the American corporate governance system and how voting is presently employed in it.

\section{DETERMINING THE ROLE OF SHAREHOLDER VOTING IN CORPORATE GOVERNANCE}

\section{A. A PRIMER ON SHAREHOLDER VOTING}

In the United States, most public corporations are effectively run by corporate management. ${ }^{24}$ This is a function of the economic reality that large, diverse businesses need centralized management in order to facilitate productive business activity. There are tremendous efficiencies created by having a hierarchical decisionmaking structure that concentrates power in the hands of professionally-trained, highly skilled personnel. ${ }^{25}$ As a result, our corporate governance system gives the chief executive officer ("CEO") of the company the power to make most important corporate decisions in order to operationalize these efficiencies.

However, the underlying legal structure of state corporate law filters this economic reality. The common core of American corporation statutes is a clear statement that all corporate power is placed in, or under the authority of, the board of directors. ${ }^{26}$ But the board is comprised of part-

24. Melvin A. EISENBerg, The Structure of the Corporation: A legal ANalysis 13941 (1976).

25. Stephen M. Bainbridge, Responses, Director Primacy and Shareholder Disempowerment, 119 HARV. L. REV. 1735, 1746-51 (2006).

26. DEL. CODE ANN. tit. 8, $\$ 141$ (a) (2011) ("The business and affairs of every corporation organized under this chapter shall be managed by or under the direction of a board of directors ...."); MODEL BUS. CORP. ACT $\S 8.01$ (b) (2011) ("All corporate powers shall be exercised by or under the authority of the board of directors of the corporation, and the business and affairs of the corporation shall be managed by or under the direction, and subject to the oversight, of its board of directors ...."). 
time directors, many of whom have other full-time jobs, who can spend little time worrying about the problems of the corporation. These directors cannot effectively employ the control rights that the statutes provide them and instead largely delegate to the corporation's officers the responsibility to run the corporation. ${ }^{27}$ Only in "crisis" situations will the board exercise their ultimate power to approve, or override, corporate managers' key decisions about the corporation's future. ${ }^{28}$

In this legal structure, shareholders play a crucial, but decidedly subordinate, governance role. In contrast to the plenary role of the directors and the managers, shareholders can do only a few things-voting, selling, and suing - each in very limited doses. ${ }^{29}$ These shareholder roles often reflect a monitoring function. Managers of a corporation, as the holders of day-to-day power over the sometimes vast aggregations of other people's money, require some form of monitoring. Without any monitoring, managers would be tempted to shirk their duties or divert assets to their own private benefit. ${ }^{30}$ Directors, of course, have the responsibility to monitor corporate management, including the power to replace officers if they find their performance lacking or detect managerial misconduct. But directors are generally nominated to the board with management's consent and may fear engaging in close monitoring of management. ${ }^{31}$ This creates an important role for shareholders to play, for without shareholder monitoring, the cost of capital would rise in order to mitigate investors' concerns about misappropriation of corporate resources or a lack of effort by the managers. ${ }^{32}$

Among the three methods for shareholders to act as monitors, selling and suing have significant limitations. Selling shares effectively disciplines management only if the market for corporate control is robust. Defensive tactics such as the poison pill effectively make selling dependent on a prior successful voting campaign whenever the target board opposes the deal. ${ }^{33}$

27. EISENBERG, supra note 24 , at 140; DEL. CODE ANN. tit. $8, \S 142$; MODEL BuS. CoRP. ACT $\S \S 8.40-.44$.

28. One important example under Delaware law is when a corporation is being put up for sale. Revlon, Inc. v. MacAndrews \& Forbes Holdings, Inc., 506 A.2d 173, 180 (Del. 1985). A second example occurs when the board determines that it needs to replace the CEO of the company because of poor corporate performance.

29. Robert B. Thompson, Preemption and Federalism in Corporate Governance: Protecting Shareholder Rights to Vote, Sell and Sue, 62 LAw \& CONTEMP. ProBs. 215, 216-18 (1999).

30. Michael C. Jensen \& William H. Meckling, Theory of the Firm: Managerial Behavior, Agency Costs and Ownership Structure, 3 J. FIN. ECON. 305, 323-28 (1976).

31. EISENBERG, supra note 24, at 145-47.

32. Jensen \& Meckling, supra note 30, at 312-13.

33. Paul H. Edelman \& Randall S. Thomas, Selectica Resets the Trigger on the Poison Pill: 
Shareholder suits against the corporation also face significant barriers. ${ }^{34}$ And even if successful, the remedy is often a payment out of the corporation's coffers, which does little to deter future wrongdoing by managers.

Can voting play a more effective role as a monitoring device? Delaware Chancellor William Allen once described shareholder voting as the ideological underpinning that "legitimates the exercise of power by some (directors and officers) over vast aggregations of property that they do not own." 35 Abstractly speaking, we could put voting at the center of corporate governance by starting from a philosophical foundation of popular sovereignty parallel to what we see in our polity. ${ }^{36}$ In this view, shareholders are the ultimate repository of corporate authority, just as citizens are the font of power in the republic. While recurring references to shareholders as owners of the corporation reflect this view, the reality is more complex because of the importance of centralized management in our system.

Giving shareholder voting too broad a role imperils the efficiencies of centralized management by replacing management decisionmaking with shareholder decisionmaking. ${ }^{37}$ State corporate law reflects this by strictly limiting the areas where shareholders are given a right to vote: they elect directors; they approve certain fundamental changes such as a merger (but only after directors have consented to the action); and they can sometimes amend the corporation's bylaws. ${ }^{38}$ Federal securities or tax law provides additional opportunities for shareholder voting, although usually only of an advisory nature. For example, the Dodd-Frank Wall Street Reform and Consumer Protection Act ("Dodd-Frank") mandates an advisory vote on

Where Should the Delaware Courts Go Next?, 87 IND. L.J. 1087, 1087-88, 1093-94 (2012). See also Steven Davidoff Solomon, With Fewer Barbarians at the Gate, Companies Face a New Pressure, N.Y. TIMES (July 30, 2013, 1:49 PM), http://dealbook.nytimes.com/2013/07/30/with-fewer-barbarians-at-thegate-companies-face-new-pressure/ (noting that "companies have fought over the last 30 years to kill the hostile takeover" by adopting poison pills and lobbying state legislatures for anti-takeover statutes, resulting in fewer hostile takeover attempts).

34. Robert B. Thompson \& Randall S. Thomas, The New Look of Shareholder Litigation: Acquisition-Oriented Class Actions, 57 VAND. L. REV. 133, 136 (2004) (highlighting additional requirements for plaintiffs bringing representative shareholder suits).

35. Blasius Indus. Inc. v. Atlas Corp., 564 A.2d 651, 659 (Del. Ch. 1988).

36. Lee Harris, The Politics of Shareholder Voting, 86 N.Y.U. L. REV. 1761, 1782-85 (2011) (comparing shareholder voting in corporate elections to citizen voting in political elections).

37. See David Yermack, Shareholder Voting and Corporate Governance, 2 ANN. REV. FN. ECON. 103, 105-08 (2010) (summarizing papers on the design, administration, and impact on corporations of shareholder voting).

38. 2 JAMES D. COX \& THOMAS LEE HAZEN, THE LAW OF CORPORATIONS $\S 13.1$ (3d ed. 2010 ). 
executive compensation ("Say on Pay"), ${ }^{39}$ while Rule 14a-8 allows shareholders to make precatory proposals on a broad range of governance and social issues. ${ }^{40}$ Shareholder approval is generally necessary for stock option plans if the company is seeking to qualify the options for preferential federal tax treatment. ${ }^{41}$ Finally, shareholders can themselves initiate action in a limited number of settings. Thus, in Delaware (and most other states), shareholders, at least in the abstract, have the power to call a special meeting, to use the written consent procedure, or to take any action that shareholders are permitted to take at a regular annual shareholders meeting. ${ }^{42}$

Corporate voting has been most important as a mechanism to bring about a change of control of the board. While the overwhelming majority of elections of directors involve only one slate of candidates, contested elections of directors arise whenever a dissident group of shareholders nominates an alternative slate of directors. ${ }^{43}$ Insurgents can seek to unseat the entire board of directors ("proxy contests for corporate control") or they can nominate a minority of directors in an effort to gain a voice on the board ("short slate contests"). Proxy contests for corporate control are frequently combined with hostile tender offers, where the potential buyer seeks to gain control of the target firm's board of directors to remove the target's poison pill, thereby permitting the target shareholders to sell their shares without the bidder suffering massive dilution if it closes its offer. ${ }^{44}$

A favorable shareholder vote is also needed to approve mergers or certain other fundamental transactions, ${ }^{45}$ when management seeks to change the corporation's charter to implement a classified board of

39. Dodd-Frank Wall Street Reform and Consumer Protection Act ("Dodd-Frank"), Pub. L. No. 111-203, sec. 951, 124 Stat. 1375, 1899 (2010) (adding new section 14A to the Securities Exchange Act of 1934). See also Thomas, Palmiter \& Cotter, supra note 4, at 1224-25 (explaining section 951 of Dodd-Frank, which requires a shareholder advisory vote on executive compensation for the prior fiscal year).

40. 2 COX \& HAZEN, supra note $38, \S 13.32$ (discussing shareholder use of Rule 14a-8, requiring management to submit shareholder proposals for a shareholder vote).

41. Randall S. Thomas \& Kenneth J. Martin, The Determinants of Shareholder Voting on Stock Option Plans, 35 WAKE FOREST L. REV. 31, 47-48 (2000).

42. RaNDALl S. ThOMAS \& CATHERINE T. DiXON, ARANOW \& EINHORN ON PROXY CONTESTS FOR CORPORATE CONTROL $\S \S 4.02(C)$ (3)-(4), 4.04(B) (3d ed. Supp. 2001) (discussing the requirements under state law for stockholders to compel a special meeting and the requirements for stockholders to use the written consent mechanism).

43. Id. $\S 4.02(\mathrm{C})(1)$.

44. See Randall S. Thomas, Judicial Review of Defensive Tactics in Proxy Contests: When is Using a Rights Plan Right?, 46 VAND. L. REV. 503, 504-05, 510-12 (1993) (describing proxy contests for corporate control and the use of "rights plans" (known as posion pills) as a defensive tactic).

45. 2 COX \& HAZEN, supra note $38, \S 13.1$. 
directors, ${ }^{45}$ or to effect a dual class recapitalization. ${ }^{47}$ In these settings, the vote permits shareholders to monitor director decisions that may be distorted by management self-interest.

Advisory shareholder votes can lead to important governance changes. ${ }^{48}$ The Shareholder Rights Project, for example, has consistently garnered over 80 percent shareholder support for Rule 14a-8 board declassification proposals at Fortune 500 companies. ${ }^{49}$ Many of the boards of companies receiving these proposals subsequently asked their shareholders to vote on proposed charter amendments to remove their classified boards, which the shareholders then overwhelmingly approved. ${ }^{50}$

While providing for shareholder voting in the areas just outlined, corporate statutes have a distinctly contractarian flavor as to who exercises that vote. The firm's incorporation documents can limit or deny the vote to most shareholders so long as there is at least one share with full voting power, ${ }^{51}$ and prominent companies, such as Google, have made use of that private ordering possibility. ${ }^{52}$

46. See Sanjai Bhagat \& James A. Brickley, Cumulative Voting: The Value of Minority Shareholder Voting Rights, 27 J.L. \& ECON, 339, 353-62 (1984) (finding negative abnormal stock returns when firms classify boards of directors or eliminate cumulative voting).

47. Stock exchange rules will limit this type of recapitalization for existing listed public companies. See NEw YoRK STOCK Exchange LiSTEd COMPANY MANUAL $\S \S 313.00-40$ (2014), available at http://nysemanual.nyse.com/LCMTools/PlatformViewer.asp?searched=1 \&selectednode= chp_1_4_13_1\&CiRestriction=dual\&manual= $\% 2 \mathrm{Flcm} \% 2 \mathrm{Fsections} \% 2 \mathrm{Flcm}-$ sections $\% 2 \mathrm{~F}$. Dual class recapitalizations may have other adverse consequences for shareholders besides the loss of voting control. See Steven Davidoff Solomon, Thormy Side Effects in Silicon Valley Tactic to Keep Control, N.Y. TIMES (Sept. 3, 2013, 5:16 PM), http://dealbook.nytimes.com/2013/09/03/thorny-side-effects-insilicon-valley-tactic-to-keep-control/ (pointing out that technology companies with dual class structures may have trouble sustaining themselves once founders leave and control remains in management's hands).

48. See, e.g., Thomas, Palmiter \& Cotter, supra note 4, at 1213 (analyzing Say on Pay advisory voting and its impact on executive compensation).

49. Lucian Bebchuk, Scott Hirst \& June Rhee, Toward Board Declassification in $100 S \& P 500$ and Fortune 500 Companies: The SRP's Report for the 2012 and 2013 Proxy Seasons, HARV. L. SCH. FORUM ON CORP. GOVERNANCE AND FIN. REG. (Feb. 25, 2014, 9:12 AM), http://blogs.law.harvard.edu/corpgov/2014/02/25/toward-board-declassification-in-100-sp-500-andfortune-500-companies-the-srps-report-for-the-2012-and-2013-proxy-seasons/ (announcing that the Project had submitted fifty-eight successful precatory proposals seeking the removal of classified boards, with average support of 81 percent).

50. Id.

51. E.g., DEL. CODE ANN. tit. 8, $§ 151$ (b) (2011) ("Any stock of any class or series may be made subject to redemption by the corporation at its option or at the option of the holders of such stock or upon the happening of a specified event; provided however, that immediately following any such redemption the corporation shall have outstanding 1 or more shares of 1 or more classes or series of stock, which share, or shares together, shall have full voting powers.").

52. Davidoff Solomon, supra note 47. 


\section{B. Why SHAREHOLDERS HAVE VotING RIGHTS}

Next we present a positive theory of shareholder voting. A few caveats before we begin. First, we are not making normative claims about the merits of shareholder voting. We are agnostic on the question of whether shareholder voting leads either to social or corporate efficiency. We offer a positive theory that explains what we observe in the world about the role of the shareholder franchise.

Second, we restrict our analysis to publicly traded corporations with dispersed ownership. There is little doubt that shareholder voting in other contexts, for example, close corporations or firms with a single majority owner, has different characteristics. In those contexts, we would anticipate additional or different roles for voting. We focus on publicly traded corporations because they are the most significant ones economically and are the most affected by intermediary capitalism.

Third, we focus on mandatory voting rights, that is, situations in which shareholders are obligated to vote on certain issues. Institutional investors, who hold the vast majority of large public companies' stock, are obligated to vote their shares by government regulation, as we discuss in Part II. They are faced with a large number of mandatory votes each year because they hold diversified portfolios of stock, often including several thousand portfolio companies. Mandatory voting rules are also particularly important at public companies where significant collective action problems make it difficult for shareholders to negotiate value-maximizing contractual voting rights. By enforcing a mandatory vote, the government solves the collective action problem that might otherwise result in too little voting. However, our theory provides an important baseline justification for corporate voting in general and could potentially be extended to the analysis of purely contractual voting. ${ }^{53}$

Traditional theory has justified the shareholder franchise based on a shareholder's status as either an owner of the residual interest in the firm or as a principal in a principal-agent relationship with directors and management. This theory has proven inadequate to capture the role shareholders actually have under corporate law or the changed nature of shareholders in today's world of intermediary capitalism.

53. For example, we leave for another day questions that arise about the appropriate form of venture capitalists' contractual voting rights in start-up firms. See, e.g., Jesse M. Fried and Mira Ganor, Agency Costs of Venture Capitalist Control in Startups, 81 N.Y.U. L. REV. 967, 967 (2006) (discussing how the governance structure of venture capitalist-backed startups can lead to high agency costs due to preferred shareholder control of the board and thus the firm). 
For example, Frank Easterbrook and Daniel Fischel have argued that shareholders' residual interest in the corporation gives them "the appropriate incentives...t to make discretionary decisions... The shareholders receive most of the marginal gains and incur most of the marginal costs. They therefore have the right incentives to exercise discretion." ${ }^{54}$ The corporation is an incomplete contract and the discretion to fill any gaps in that contract is exercised via the vote. So the right to vote follows from the shareholder's claim on the residual value of the firm, and this right extends to any issue that has not been explicitly contracted for within the corporation.

Yet shareholders, as finance theory has taught us, are not the only stakeholders with a claim to residual value. Options theory suggests that debt holders also have a claim on the residual value, ${ }^{55}$ but we rarely see debt holders having a vote unless the corporation is in financial distress. Along similar lines, many other stakeholders have claims on the residual value of the firm without receiving voting rights. ${ }^{56}$ Even the assertion that shareholders have a claim on the residual value is contingent. They cannot, as a rule, force the board to issue dividends to capture that value. ${ }^{57}$ They can only tap into the residual value of the firm if they can sell their shares and the stock market reflects the improvements in the firm in its stock price.

Similarly, Easterbrook and Fischel's theory is too broad in claiming that shareholders have the right to make all "gap-filling" decisions for the firm. ${ }^{58}$ States' corporation codes give the plenary governance role to the directors, not the shareholders. ${ }^{59}$ In other words, the board fills the gaps, and it is exactly this centralized control that some claim is the primary

54. Frank H. EASTERBROOK \& Daniel R. Fischel, The ECONOMiC Structure of CORPORATE LAW 68 (1991).

55. Lynn A. Stout, Bad and Not-So-Bad Arguments for Shareholder Primacy, 75 S. CAL. L. REV. 1189, 1192 (2002).

56. MARGARET M. BLAIR, OWNERSHIP AND CONTROL: RETHINKING CORPORATE GOVERNANCE FOR THE TWENTY-FIRST CENTURY 231-32 (1995); LYNN STOUT, THE SHAREHOLDER VALUE MYTH: HOW PUTTING SHAREHOLDERS FIRST HARMS INVESTORS, CORPORATIONS AND THE PUBLIC 41 (2012).

57. Kamin v. Am. Express Co., 383 N.Y.S.2d 807, 810-12 (N.Y. Sup. Ct. 1976), aff'd, 387 N.Y.S.2d 993 (N.Y. App. Div. 1976) (applying business judgment rule and dismissing shareholder suit seeking to force the board to pay a dividend).

58. EASTERBROOK \& FISCHEL, supra note 54, at 66.

59. See DEL. CODE ANN. tit. 8, $\$ 141$ (a) (2011) ("The business and affairs of every corporation organized under this chapter shall be managed by or under the direction of a board of directors ...."); MODEL BUS. CORP. ACT $\S 8.01$ (b) (2011) ("All corporate powers shall be exercised by or under the authority of the board of directors of the corporation, and the business and affairs of the corporation shall be managed by or under the direction, and subject to the oversight, of its board of directors ...."). 
benefit of the corporate form. ${ }^{60}$

Moreover, Easterbrook and Fischel's theory could justify shareholders voting on almost any set of issues. According to them, shareholders are allowed to delegate much of their power to the board, but they offer no description of when they would be likely to do so, so that their theory is consistent with strong, weak, or virtually no, shareholder voting. We prefer a model which gives a better descriptive account of voting as it exists today.

A second theory of shareholder voting rights is based on Michael Jensen and William Meckling's claim that the exchange of equity for capital establishes a principal-agent relationship between the shareholders and the board of directors. ${ }^{61}$ An agent, the board, will be tempted to extract private benefits using its control of the firm's assets, and so the principals, the shareholders, must monitor the agent to protect their interests. There will be a trade-off between the price of equity and the amount of monitoring imposed-the less monitoring imposed, the higher the risk to the shareholder and hence the cost of equity to the firm should increase. Under this view, shareholder voting is one monitoring mechanism.

Jensen and Meckling are describing a principal-agent model based on elements of economics and theories of the firm that only incompletely translate to law. The common law, and particularly the law of agency, have a more robust view of agency that imposes fiduciary duties on agents "when one person (a 'principal') manifests assent to another person (an 'agent') that the agent shall act on the principal's behalf and subject to the principal's control, and the agent manifests assent or otherwise consents so to act." 62 But the law is clear that the shareholder-director relationship does not come within this legal concept. Directors have the autonomous power to make virtually all business decisions under all the states' corporate statutes, which is difficult to reconcile with them being under the shareholders' "control." Moreover, the law does not generally require the board to act on behalf of the shareholders. Indeed, the Restatement (Third) of Agency states explicitly: "Although a corporation's shareholders elect its

60. Stephen M. Bainbridge, The Case for Limited Shareholder Voting Rights, 53 UCLA L. REV. 601, 619-28 (2006) (arguing that the system of the separation of ownership and control of a corporation has benefited investors and society).

61. Jensen \& Meckling, supra note 30, at 312-13. This is a theoretical refinement of Adolf A. Berle, Jr. and Gardner C. Means's observation of the separation of ownership and control in the modern corporation. Adolf A. Berle, JR. \& Gardner C. MEANS, The Modern Corporation and Private PROPERTY 119-20 (1933).

62. RESTATEMENT (THIRD) OF AGENCY $§ 1.01$ (2006). 
directors and may have the right to remove directors once elected, the directors are neither the shareholders' nor the corporation's agents as defined in this section, given the treatment of directors within contemporary corporation law in the United States."

For theoretical purposes, this deficiency need not be fatal. In fact, Jensen and Meckling describe an agency relationship more loosely "as a contract under which one or more persons (the principal(s)) engage another person (the agent) to perform some service on their behalf which involves delegating some decisionmaking authority to the agent." ${ }^{\text {" }}$ Is there an agency relationship between shareholders and the board in this more informal sense? Superficially we might think so, but it depends on the characterization of the transaction between the shareholders and the corporation. If the corporation has issued debt, then we might equivalently view the shareholders as having purchased a call option from the debt holders. From this perspective there is no principal-agent relationship between shareholders and the board, but instead one between debt holders and the board. Indeed as one explores alternative interpretations of the financial relationships among stakeholders in the corporation through the lens of options theory, it becomes clear that there is arbitrariness to assigning control and duties among the participants. ${ }^{65}$

But even if we credit this principal-agent relationship, it still may not justify shareholder voting. While voting may act as a monitoring device to lower capital costs, so could other forms of monitoring such as the market for corporate control or shareholder litigation. Alternatively, shareholders could choose to trade voting rights for a higher return on their stock. In the language of Oliver Williamson's transaction cost model of the corporation, ${ }^{66}$ granting the vote to the shareholder permits the corporation to lower its cost of capital by providing assurances to the shareholders that their asset-specific investments will not be misappropriated. But why should this trade-off always result in a vote for shareholders and a lower price of capital instead of no shareholder vote and a higher stock price?

In fact, sometimes corporations opt for the latter arrangement. In the initial public offering of Google's dual classes of shares, the public market

63. Id. $§ 1.01 \mathrm{cmt} . \mathrm{f}(2)$ at 29 .

64. Jensen \& Meckling, supra note 30 , at 308.

65. Frank Partnoy, Adding Derivatives to the Corporate Law Mix, 34 GA. L. REV. 599, 608-12 (2000).

66. Oliver E. Williamson, Transaction Cost Economics, in 1 HANDBOOK OF INDUSTRIAL ORGANIZATION 135, 136 (Richard Schmalensee \& Robert D. Willig eds., 1989). 
in its reduced-voting shares was quite robust. ${ }^{67}$ Why would shareholders agree to take equity positions in a company with no real voice and no assurance of return? Evidently they thought they would see an adequate future return without being able to control the company's directors. Google executives, by paying their employees in stock (and stock options) have effectively bonded themselves ${ }^{68}$ to an alternative monitor, their own employees. So perhaps the shareholders of Google felt assured that their interests would be adequately represented to the board through this alternative mechanism.

Under this contractarian approach to the corporation, shareholders have the right to vote because they contracted for it. If they choose to invest in companies without voting rights and alternative monitoring mechanisms, then either the equity holders got a great price, or they believe the board will perform its duties, or some combination of the two. But we cannot know which, and certainly the granting of a vote is not a requirement for the "right" contract.

Is there a better theoretical foundation for giving shareholders the vote? There is one way in which shareholders are unique in their relationship to the corporation-they are the sole stakeholders whose return on investment is tied closely to the stock price of the corporation. The only way shareholders can be sure of getting a return on their investment is to sell the stock at market price and realize a capital gain (or loss). They cannot be assured of a dividend distribution or any other payment from the corporation, because only the directors can make those decisions. All other stakeholders-employees, debt holders, suppliers-largely know what their returns will be, subject to assorted risks associated with any contractual relationship. ${ }^{69}$

67. Steve Gelsi, Google Closes Above $\$ 100$ a Share, MarketWatch: WaLl ST. J. (Aug. 19, 2004, 6:50 PM), http://www.marketwatch.com/story/google-shares-rise-18-on-first-day-close-above100/print?guid=892B3D22-B024-4119-A5EB-A56E2DD46100 ("The Google IPO consists of Class A shares, which have one-tenth of the voting power of the company's 237.6 million Class B shares, which are held by insiders."). See also Dan Gallagher, By Some Measures, Google Shares Are Much Cheaper at Its 9-Year IPO Anniversary, MARKETWATCH: WALL ST. J. (Aug. 19, 2013, 12:30 PM), http://blogs.marketwatch.com/thetell/2013/08/19/by-some-measures-google-shares-are-much-cheaperat-its-9-year-ipo-anniversary/ (showing the market strength of Google shares with limited voting power since their initial public offering in 2004); Davidoff Solomon, supra note 47 (discussing Google's efforts in 2013 to offer shares with no voting rights).

68. Jensen \& Meckling, supra note 30, at 323-26.

69. The recent trend to tie "pay for performance" by including stock in the compensation packages for management somewhat complicates this analysis. There is much debate as to the effect of this type of package. For the purposes of this Article, however, we will lump management holding shares with the other stockholders. But, as described above, if equity constitutes a substantial portion of 
We will assume that the share price is positively correlated with the residual value of the firm. ${ }^{70}$ We will also assume that stock markets are given sufficient information about publicly traded firms so that the residual value is generally accurately reflected in the share price. ${ }^{71}$ Consequently, shareholders are the only corporate stakeholders whose return is dependent on both the residual value of the firm and the provision of accurate information to the stock market. So it is in the interest of the shareholders that the firm's residual value be maximized and that this value be accurately reflected in the market. There is almost no way for the shareholders to contractually obligate corporate directors to do this. It is for this reason that shareholders may require some voice in the firm.

The fact that shareholders are motivated by the residual value of the firm and dependent on efficient capital markets has ancillary social benefits. While the residual value of the corporation may not be the only measure of board success, it certainly is an important one. ${ }^{72}$ So, to the extent that shareholders insist on having a vote as a part of the negotiation for an equity stake, we might well expect that their influence will, on average, be positive for the well-being of the corporation.

As discussed earlier, shareholders typically have three different ways to voice their concerns to the corporation: sue, sell, or vote. ${ }^{73}$ Why are the first two options insufficient? Suing generally has very large transaction costs: legal fees are high, acquiring information (for example, discovery) is costly, and the judicial system moves slowly. Moreover, courts may not be competent to make decisions about corporate policy. ${ }^{74}$ Even so, lawsuits

compensation across the institution, then it may act as a bonding method by the board and thus serve as an alternative monitoring mechanism.

70. EASTERBROOK \& FISCHEL, supra note 54, at 18-20.

71. See StePhen A. Ross, RandolPh W. WeSterfield \& JEFFrey F. JaFFe, CorPorate FINANCE 459 (9th ed. 2010) (discussing efficient capital markets and how "market efficiency implies that stock prices reflect all available information").

72. Lynn Stout justifies shareholder voting in a similar way. While she advances a teamproduction theory of the corporation, she acknowledges the criticism that such a theory has the potential to give too much leeway to the decisions of management-leaving them able to justify any decision, even ones that result in self-interested behavior-because there are few objective indicia for their performance. Thus, as a second-best solution, she proposes that using stock price as a general proxy for the performance of the board, and thus using the shareholders as monitors, might cabin board behavior to achieve superior firm performance. She views this as a purely empirical question-does monitoring by shareholders through the vote achieve better results than letting the board act without such monitoring? See Stout, supra note 55, at 1199-1201.

73. Thompson, supra note 29 , at 216-18.

74. See Brehm v. Eisner, 746 A.2d 244, 266 (Del. 2000) (refusing to second guess board's decision to award compensation package to departing executive). One main reason for the business judgment rule is that boards are much better situated than courts to make business decisions. 2 Cox \& 
coupled with securities regulations can help ensure that stock markets receive accurate information about a corporation. But the barriers to successful lawsuits are getting higher as corporations seek to adopt bylaw provisions requiring shareholders to arbitrate, rather than litigate, disputes with the corporation. ${ }^{75}$ And even when shareholders retain the right to go to court, choice of venue provisions can make suits more difficult. ${ }^{76}$

What about the option to sell? Unhappy shareholders can convey their frustration with the board by selling their shares. Of course, a selling shareholder is forced to lock in a lower valuation than she thinks she deserves, thereby losing investment returns. For that reason, making selling the only monitoring mechanism is not an attractive option.

Selling might be an effective monitoring tool in two situations. First, a robust market for corporate control would cause competition for shares that would push the market valuation of the company closer to its actual residual value. ${ }^{77}$ This would allow shareholders to get a fair valuation for their shares because underperforming companies would get taken over at a bargain price, ${ }^{78}$ vitiating the need for other forms of monitoring. Today, however, numerous defensive tactics, such as poison pills and classified boards, can be deployed to prevent a corporate takeover, leaving this market quite weak.

A second way that selling shares can be an effective monitoring device stems from stock-based compensation for managers. If other shareholders sell their shares, this will put downward pressure on the stock price, lowering the value of managers' shares. This may lead managers to pay more attention to the shareholders' concerns. While plausible, this scenario requires that management compensation be closely tied to the share price and that managers' stockholdings be a substantial percentage of their wealth. Yet, if this is the case, concentrated selling may give

HAZEN, supra note 38, $\S 10: 2$ (describing the business judgment rule). See also Kamin v. Am. Express Co., 383 N.Y.S.2d 807, 810-12 (N.Y. Sup. Ct. 1976), affd, 387 N.Y.S.2d 993 (N.Y. App. Div. 1976) (on file with authors) (applying the business judgment rule and refusing to second guess a board's decision to refrain from paying out a shareholder dividend).

75. E.g., Second Amended Class Action and Derivative Complaint at 51-52, Cent. Laborers' Pension Fund v. Portnoy, No. 24-C-13-1966 (Balt. Cir. Ct. May 31, 2013) (arguing that an arbitration provision added as a bylaw should be considered invalid because shareholders never voted on the bylaw).

76. E.g., Boilermakers Local 154 Ret. Fund v. Chevron Corp., 73 A.3d 934, 939 (Del. Ch. 2013) (holding that unilaterally adopted bylaws requiring Delaware as the forum for litigation were facially valid under Delaware law).

77. Henry G. Manne, Mergers and the Market for Corporate Control, 73 J. PoL. ECON. 110, 112-14 (1965). There are significant transactions costs inherent in takeover bids, though.

78. Id. 
shareholders too much sway over the performance of management.

We conclude that voting, when applicable, is the most desirable form of monitoring. Moreover, voting provides additional positive benefits to the corporation. In some circumstances, it allows shareholders to aggregate private information and thus acts to correct board errors. ${ }^{79}$ In other settings, it can act to aggregate the heterogeneous preferences of the shareholders. ${ }^{80}$ Both of these functions will be discussed further in the next section.

We close this section with two important notes. First, we are not claiming that shareholder voting must be universal. Shareholders may choose to give up the vote in favor of a better price for equity, higher expected returns, or relying on incentives in place given the market or corporate governance provisions and other disciplining mechanisms. However, as an empirical matter, for public corporations in the United States, the opportunity for shareholders to make such trade-offs and invest in dual class shares are infrequent because stock exchange rules prohibit new midstream dual class recapitalizations. ${ }^{81}$ This means that dual class shares are largely sold only in a small set of initial public offerings.

Second, we are not arguing that the board is required to maximize the stock price. With the exception of Revlon settings, ${ }^{82}$ there is no legal requirement that they do so. Even though voting gives shareholders a voice in some decisions, the board is not required generally to heed that voice. Shareholders are only one of the stakeholders that influence the board, except in those rare settings where they must approve board action or initiate it on their own. Giving shareholders a vote is far different from giving them control.

\section{WHEN SHOULD SHAREHOLDERS VOTE?}

If shareholder voting is desirable, then when should shareholders vote - on every business decision, or just those mandated by corporate statutes $?^{83}$ In this section, we offer three theories about what shareholders

79. See infra Part I.C.2.a.

80. See infra Part I.C.2.b.

81. For an insightful analysis of the shareholder voting issues surrounding midstream dual class recapitalizations, see Jeffrey N. Gordon, Ties That Bond: Dual Class Common Stock and the Problem of Shareholder Choice, 76 CALIF. L. REV. 3 (1988).

82. Revlon, Inc. v. MacAndrews \& Forbes Holdings Inc., 506 A.2d. 173, 182 (Del. 1986) (holding that a board has a duty to shareholders to maximize shareholder retum in a sale of control).

83. Stephen M. Bainbridge argues that voting's transaction costs are so high, and its benefits so diffuse, that shareholders should not vote at all. Bainbridge, supra note 60 , at $622-24$. We agree that efficiency constraints are important, and we consider them in this part, but they implicate whether shareholders will participate in the voting process rather than the theoretical role shareholders should 
should vote on. The first is based on the importance of shareholder monitoring. Corporate officers have great power, and boards of directors, while possessing seemingly endless legal authority over officers, have a limited ability to practically monitor how managers use their power. A shareholder vote can play a monitoring role if the issue being decided affects the company's stock price, or long-term value, and if the shareholder vote is likely to be superior, or complementary, to that of the board of directors as a monitoring mechanism. This is particularly likely to be the case in situations where the officers or directors of the company suffer from a conflict of interest or may otherwise be seeking private benefits at the expense of the firm. Voting plays a negative role by stopping value-decreasing transactions.

Our remaining two theories provide positive reasons for corporate voting by enhancing the board's decisionmaking beyond merely monitoring it. We claim that corporate voting provides: (1) a superior information aggregation device for private information held by shareholders when there is uncertainty about the correct decision; and (2) an efficient mechanism for aggregating heterogeneous preferences when the decision differentially affects shareholders.

\section{Shareholder Monitoring Theory: What Shareholders Should Vote On}

Shareholder voting is an important monitoring mechanism in many situations. ${ }^{84}$ As developed in Part I.A, our rationale for shareholders monitoring through voting-they are the unique stakeholders whose assured return is contingent on the stock price-limits the appropriate range of issues for shareholder voting. Looking at the spectrum of all instances where shareholders currently vote, we see at one end voting to approve a merger or the sale of all, or substantially all, the assets of the corporation. This type of vote falls squarely into those questions appropriate for shareholder monitoring because these sales implicate the stock price and deserve shareholder scrutiny. In a management buyout transaction, for example, the board frequently is conflicted, or at least captured, and may be helping management to reap gains at the expense of the firm, especially if the proposed merger was a defensive one, designed to thwart potential hostile acquirers. In this case, a shareholder vote approving the merger plays an important monitoring function that

play.

84. See, e.g., Lucian A. Bebchuk, The Case for Increasing Shareholder Power, 118 HARV. L. REv. 833, 865-70 (2005) (discussing the benefits of allowing shareholders to have increased voting powers). 
backstops the board's decision and is not overly costly. At the other end of the spectrum, we put precatory votes on social policy issues with little likelihood of affecting share price. Shareholders have no special interest in such votes and little incentive to monitor them. ${ }^{85}$ Shareholders who object have an easy and inexpensive remedy-sell their stock.

The costs of voting are an important consideration. ${ }^{86}$ There is a serious collective action problem in shareholder voting: the benefits of a successful vote accrue to all shareholders but the costs of voting (for example, information acquisition, preparation and distribution of materials, mustering support) are borne by each voter separately so that shareholders may have inadequate incentives to vote. But there are ways to overcome this problem in corporate voting. For example, mutual funds are required by legal rules to cast informed votes. ${ }^{87}$ Other shareholders, such as hedge funds, can accumulate voting shares to increase their returns from voting, making it efficient for them to vote on an informed basis. Since institutions are often required to vote, or find it economically desirable to vote, the market has responded to their need for information through the development of proxy advisory firms, such as ISS, that efficiently gather this information. Moreover, shareholders' costs have also been dropping due to the acceptance of e-proxy as a means of disseminating information. $^{88}$

We are describing necessary conditions for the benefits of shareholder voting, not sufficient ones. In particular, there are situations in which the board may be conflicted in a way that affects share price but where shareholders can free ride on the monitoring by other constituencies. For example, it would be reasonable for shareholders to rely on the debt markets to monitor assumptions of a large amount of debt. Such monitoring is free to the shareholders and so they avoid any of the costs of voting.

To summarize, our shareholder monitoring justification for corporate

85. Randall S. Thomas \& James F. Cotter, Shareholder Proposals in the New Millennium: Shareholder Support, Board Response, and Market Reaction, 13 J. CORP. FIN. 368, 370 (2007) ("Academic research has generally concluded that corporate governance proposals raise important substantive issues, while social responsibility proposals are frequently viewed as frivolous.").

86. The importance of considering the costs of shareholder voting is made forcefully in Bainbridge, supra note 60 , at 622-24.

87. See infra Part II.A.3.

88. Jeffrey N. Gordon, Proxy Contests in an Era of Increasing Shareholder Power: Forget Issuer Proxy Access and Focus on E-Proxy, 61 VAND. L. REV. 475, 487-89 (2008) (noting that the SEC e-proxy rules, adopted in 2008 , could reduce costs for shareholders, since the e-proxy system "ultimately may reduce the cost of engaging in proxy contests, thereby increasing the effectiveness and efficiency of proxy contests as a source of discipline in the corporate govemance process."). 
voting can be stated as follows. A shareholder vote may be justified if: (1) the issue affects stock value immediately or in the long term; ${ }^{89}$ (2) management is either conflicted or the board is likely to be captured; and (3) the systemic benefits that will be realized from monitoring by the shareholders exceed the costs of monitoring. To this point, we have assumed that the role of the shareholder vote is to monitor the behavior of a potentially conflicted, or captured, board that shareholders think will not be adequately disciplined by other monitors. Implicit in that analysis is that there is a correct answer as to what maximizes share price, but the shareholders cannot rely on the board to reach that conclusion because of its private incentives. Monitoring thus plays a negative role in stopping board misconduct or mistakes.

\section{Alternative Justifications for Shareholder Voting}

In addition to our shareholder monitoring theory, there are two other important justifications for a shareholder vote enhancing the decisionmaking of the board beyond merely monitoring it. First, when there is uncertainty about what is the correct decision, a shareholder vote can aggregate private information available to shareholders. Second, when there is no objectively correct decision to be made, but rather the decision will affect different shareholders in different ways, a shareholder vote will effectively aggregate the heterogeneous preferences of the shareholders.

\section{a. Private Information Aggregation}

Suppose that an action will have an uncertain effect on the share price and that each voter is more likely than not to be correct about what that effect will be. Two of us have argued that voting is an excellent way to aggregate private information in an uncertain world. ${ }^{90}$ Then a decision by a majority vote will have a very high probability of being correct, and the larger the electorate, the more likely the majority vote will be correct. For example, in an arm's length merger, if there is some uncertainty about whether the merger price is fair, then a shareholder vote is more likely to get the correct answer than a mere vote of the board, even if the board is not conflicted, because of the increase in the overall number of informed

89. We include situations where managers' actions affect the "long-term value" (as opposed to the immediate stock price) of the company, although we recognize that there is ongoing debate on whether it is possible to enhance long-term value in a way that is not reflected in the actual stock price. See supra note 15 . However, as we hear corporate boards routinely making the claim that long-term value is different from stock price value, we think that their actions should be monitored by the shareholders when they claim that such a divergence exists from stock prices.

90. Thompson \& Edelman, supra note 21, at 149. 
voters: ${ }^{91}$ In this way, a shareholder vote can act as an error-correction device for the board decision.

The efficacy of a shareholder vote under this theory is based on a couple of assumptions. First, the vote must be on a question to which there is an objectively correct answer. Questions closely related to the stock price, such as the approval of a merger, should fall into this category. A second key assumption is that the voters, on average, are more likely than not to be correct if making this decision. ${ }^{92}$ This assumption is plausible for decisions that implicate the stock price, because shareholders, and especially institutional shareholders, have the incentive to gather the necessary information. ${ }^{93}$ Thus, for some corporate decisions, a shareholder vote can aggregate the private information held by the shareholders and lead to a better decision than one made solely by the board. ${ }^{94}$ In this way, a shareholder vote may actually improve the board's decisionmaking.

\section{b. Heterogeneous Preference Aggregation}

The second situation in which a vote by shareholders may aid the board in its decisionmaking arises when the issue differentially affects shareholders and the board wants, or needs, to know the overall preference of the shareholders. For example, Biglari Holdings ("Biglari"), a hedge fund with a 20 percent stake in Cracker Barrel Old Country Store, Inc. ("Cracker Barrel"), proposed a shareholder vote on a resolution that the corporation should take on significant debt in order to make a twenty-dollar per share dividend. ${ }^{95}$ It is possible that the dividend proposal was a valuereducing strategy, although Biglari surely did not think so. But more likely,

91. This follows from the Condorcet Jury Theorem. For the technical details see Thompson \& Edelman, supra note 21, at 132 n.5, 132-33, and see generally Paul H. Edelman, On Legal Interpretations of the Condorcet Jury Theorem, 31 J. LEGAL STUD. 327 (2002) (offering three models of the Condorcet Jury Theorem based on the way users incorporate randomness into the theorem).

92. For a technical specification of this condition, see Bernard Grofman, Guillermo Owen \& Scott L. Feld, Thirteen Theorems in Search of the Truth, 15 THEORY \& DECISION 261 (1983).

93. They may also contract out the information gathering aspect of their process to proxy advisory firms. See infra Part II.A.4 for further discussion.

94. For a longer disquisition on this conclusion, see generally Thompson \& Edelman, supra note 21 (setting forth this new error correction theory of shareholder voting based on information theory).

95. For a detailed look at the interactions between Biglari and Cracker Barrel see Cracker Barrel Old Country Stores, Inc. and Biglari Holdings Inc.: Chronology of Events Surrounding Proxy Contest for Board Representation, UNSOLICITED VIEWS (Morrison \& Foerster), June 2014 [hereinafter Cracker Barrel and Biglari Proxy Contest Chronology], available at http://media.mofo.com/files/ Uploads/Images/UV-Cracker-Barrell-Biglari-Holdings.pdf.

Biglari also ran a short slate contest to try to secure two seats on the board. Id; Kevin Roose, Taking a Page From Buffett for His Own Path, N.Y. TIMES (Feb. 6, 2012, 8:18 PM), http://dealbook.nytimes.com/2012/02/06/taking-a-page-from-buffett-for-his-own-path/. 
there was just disagreement among the shareholders as to whether they preferred to recognize an immediate short-term return or wait for a longterm one. One reasonable way to aggregate the preferences is to have a shareholder vote on the proposal, as was done in this case at the company's initiative after Biglari pushed for it (and in which the proposal was defeated). ${ }^{96}$

Different shareholders may well have different preferences about these two outcomes. Those desirous of quick returns may opt for the dividend; those with longer time horizons may prefer the company's existing business plan. The tax status of the shareholder will likely affect his or her preference amongst these choices. Also, shareholders who are risk averse might prefer the cash now rather than the expected gains in the future. Under these circumstances, voting aggregates the preferences of the shareholders on this topic. The fact that Biglari's proposal was defeated indicates that those shareholders with long-term interests outvoted those with short-term ones.

While some have argued that shareholders are in fact a homogeneous group and use that fact to justify limiting the vote to shareholders, ${ }^{97}$ the inherent heterogeneity of shareholders plays a key role in this Article. The rise of intermediary capitalism means that institutions-mutual funds, pension funds, hedge funds, and the like-are the key voting shareholders today. These institutions each face unique incentives, different from each other and certainly different from individual shareholders. Thus, in the contemporary world, the ability to aggregate preferences through a vote is critically important.

\section{Conclusion}

What we have proposed here is a positive theory of shareholder voting. Since shareholders are unique among corporate constituencies in their sensitivity to the share price, we expect that they could potentially seek to have a vote over issues that are likely to affect share price. But not all such issues are likely to be voted on because there are more efficient alternative monitors (like boards of directors) in many situations and cheaper methods of monitoring - shareholder voting on lots of issues would be costly. Thus, we would expect that only a subset of issues is actually worth the cost of active monitoring by shareholder voting. In most

96. We could envision more exotic methods than per share voting to aggregate preferences-for example, auctions--but such investigations go beyond the scope of this Article.

97. Bainbridge, supra note 60 , at $620-21$. 
circumstances, the board is likely to be the superior decisionmaker unless it is conflicted, or self-interested, in which case shareholders are likely to be better.

Our theory also advances two non-monitoring benefits that can be achieved by voting - aggregation of private information and aggregation of preferences. In these cases we need not have concern about conflict of the board because the shareholder vote has benefits even if the board is not conflicted.

\section{INCENTIVES TO VOTE (OR NOT VOTE) AND RESPONSES TO THOSE INCENTIVES}

Having developed a theory of shareholder voting that justifies giving the franchise to shareholders, and delineated the types of subjects for which a shareholder vote is beneficial for the corporation, we next address shareholders' incentives to vote. Just because shareholders should vote on a particular issue does not guarantee that they will. Voting is costly. There are information costs, organization costs, communication costs, and more. And whatever benefits are realized will be distributed among all of the shareholders. Collective action and free-rider problems are inherent to the process. So how do we provide incentives to shareholders to exercise the functions that we have outlined?

Two behavioral patterns are the focus of our concern. Nonvoting, always a worry with individual mom-and-pop shareholders, remains as large a challenge for institutional investors who have become the dominant players in the shareholder world over the last four decades. Second, even if these intermediaries overcome the disincentives to vote, conflicts of interest may lead them to vote in ways that do not maximize firm value. For shareholder voting to play its proper role, there must be adequate responses to both these problems.

Framing both questions is the vast growth of institutional investors: rising from less than 5 percent of equities in 1950, they hold 70 percent or more among our publicly held corporations today. ${ }^{98}$ These intermediaries largely reflect the particular structure of American retirement planning over the last forty years. Institutions are intermediaries, investing money for others. There are agency benefits arising from possible specialization and economies of scale that come from hiring agents. But we must balance these benefits against the costs of monitoring the agents and the losses

98. CONFERENCE BD., supra note 9, at 22 tbl.10, 27 tbl.13. 
arising from disloyalty or slacking. ${ }^{99}$ To evaluate the usefulness of shareholder voting, we must assess the alignment of the intermediaries' interests with those of their beneficiaries across the different categories of institutional investors.

The first section of Part II focuses on why shareholders do not vote. We then examine (1) the government's response to this inertia by mandating that fiduciaries' vote and (2) a key market response to this regulatory mandate, the growth of new market actors-proxy advisory firms - that provide information and services in meeting this obligation. The last section evaluates the conflicts that each of the institutions has and how public policy should address them.

\section{A. WHY DON'T SHAREHOLDERS VOTE?}

Individual shareholders routinely ignore requests to cast their proxy ballots in corporate elections, just as fewer than 60 percent of the registered voters participate in political elections. ${ }^{100}$ There are various reasons why people do not vote; in fact, in the political context, it has proven nearly impossible to give a rational actor explanation for why anyone votes at all. ${ }^{101}$ The basic problem is that the likelihood that one vote will alter the election is miniscule, while the tangible benefit of the outcome of an election is modest for any given individual, so if the act of voting entails any cost at all, it will be inefficient to cast a ballot. Moreover, there is a classic collective action problem that has to be overcome-the benefits secured by a vote are available to everyone, whether or not they have incurred the cost of casting a ballot. The best explanation for political voting is a cultural one--people like to vote because it makes them feel good.

While civic culture and feelings might lead a person to vote in a political election, this seems implausible as an explanation of corporate voting. Instead, most shareholders are motivated by economic incentives. So if shareholders vote, we would expect that they have some economic

99. Jensen \& Meckling, supra note 30, at 308-10.

100. For presidential election registered voter turnout, see National Voter Turnout in Federal Elections: 1960-2012, INFOPLEASE.COM, http://www.infoplease.com/ipa/A0781453.html (last visited Aug. 15, 2014).

101. Donald P. Green \& Ian Shapiro, Pathologies of Rational Choice Theory: A CRITIQUe of APPliCations IN POLITICAL SCIENCE 47-48 (1994). But cf. Suzanne Lohmann, The Poverty of Green and Shapiro, in THE RATIONAL CHOICE CONTROVERSY: ECONOMIC MODELS OF POLITICS ReCONSIDERED 127, 143 (Jeffrey Friedman ed., Yale Univ. Press 1996) (1995) (questioning Green and Shapiro's models showing that rational choice predicts zero voter turnout). 
reason to do so. Indeed, certain features of corporate voting mitigate the problems associated with political voting. For example, shareholders can increase their influence by accumulating shares, thereby increasing voting's expected benefits and reducing its uncertainties. This can make voting economically rational if its costs are not too high. This strategy only helps to a point, though: shareholders have finite wealth, which limits their ability to buy shares, while legal obstacles, such as the poison pill rules, may further effectively limit share ownership. ${ }^{102}$ Moreover, there remains a free-riding problem-gains flowing from a successful vote go to all shareholders, even nonvoters, while the costs are only borne by the actual voters.

How high are the costs of voting in a corporate election? It is costly to gather the information needed to make an informed vote, even though the costs are reduced by the SEC's mandatory disclosure rules. ${ }^{103}$ For shareholders, the number of votes multiplies with the number of portfolio companies they own. In addition, if a shareholder hopes to win, he or she must incur substantial extra costs to coordinate and persuade other shareholders. As a result, individual shareholders, who made up the bulk of the shareholder base in Adolf A. Berle, Jr. and Gardner C. Means theory of the corporation, have historically had little reason to vote. ${ }^{104}$ Would the rise of institutional investors in the late-twentieth century help overcome the collective action problems that plagued individual shareholders? ${ }^{105}$ We turn

102. The poison pill limits stockholders from accumulating large stakes in companies without board approval. Moran v. Household Int'l Inc., 500 A.2d 1346, 1348-49 (Del. 1985).

103. On the other side of the table, issuer costs are increased by SEC proxy rules, although the advent of e-proxy might act to lower them. Amendments to Rules Requiring Internet Availability of Proxy Materials, Exchange Act Release No. 33-9108, 17 C.F.R. \$§ 230, 240 (Feb. 22, 2010) available at http://www.sec.gov/rules/final/2010/33-9108.pdf (requiring issuers and other persons soliciting proxies to post proxy materials on an Internet website and making other changes to address lower response rates since adoption of e-proxies).

104. Eugene V. Rostow, To Whom and for What Ends is Corporate Management Responsible?, in THE CORPORATION IN MODERN SOCIETY 46, 48-49 (Edward S. Mason ed., 1959).

105. This balancing sheds light on why institutional ownership fell short of the potential that some academics initially saw for it. See, e.g., Bernard S. Black, Agents Watching Agents: The Promise of Institutional Investor Voice, 39 UCLA L. REV. 811, 812-20 (1992); Ronald S. Gilson \& Reinier Kraakman, Reinventing the Outside Director: An Agenda for Institutional Investors, 43 STAN. L. REV. 863, 863-65 (1991). Even Professor Berle at one point saw the potential for institutions and reducing agency costs, although he later pulled back. Compare William W. Bratton, Berle and Means Reconsidered at the Century's Turn, 26 J. CORP. L. 737, 752 (2001) (quoting from Berle's 1928 book suggesting institutions gather many small holdings so that protection would be worthwhile), with William W. Bratton \& Michael L. Wachter, Shareholder Primacy's Corporatist Origins: Adolf Berle and The Modern Corporation, 34 J. CoRP. L. 99, 143 (2008) (describing how Berle's position in 1954 differed from that of 1928 , as he acknowledged that his earlier position substituted institutional managers for corporate investors without having solved the problem of separation of ownership and 
next to that topic.

\section{Institutional Investors' Dominance Today and the Centrality of} Retirement Plans

Most voters in American corporations are not real people, a fact that profoundly affects the voting process in the corporate setting. Indeed, more than 70 percent of the shares of the largest American corporations are held by institutions, particularly mutual funds and pension funds. ${ }^{106}$ These institutions are usually intermediaries: they hold title to the stock, but the person who will gain or lose from the governance decisions relating to the corporation is a beneficiary. This means that the separation of ownership and control identified by Berle and Means in the 1930s has given way to a further separation within ownership in which institutions, acting as agents, exercise shareholder power.

Particularly important for our purposes, most of these institutional shares are in various forms of retirement plans, a fact that reflects the particular way the United States has chosen to fund its workers' retirement. Table 1 shows that private company pension funds, state and local pension funds, and mutual funds, all of which are largely holding retirement monies, comprise about three-fourths of the institutional holdings of equity in American corporations. Regulatory funding requirements and tax deferral have swelled dollars available to these plans, as described below. In turn, the particular characteristics of these retirement plans shape their incentives to participate in corporate governance, such as voting, as described in the following section.

control).

106. CONFERENCE BD., supra note 9, at $22 \mathrm{tbl} .10,27 \mathrm{tbl} .13$. The number is smaller if the denominator is equity in all American corporations. See FED. RESERVE BD., Z1 FINANCIAL ACCOUNTS OF THE U.S.: FLOW OF FUNDS, BALANCE SHEETS, AND INTEGRATED MACROECONOMIC ACCOUNTS FIRST QUARTER 2014 at 100 tbl.L.213 (2014), available at http://www.federalreserve.gov/ releases/z1/Current/zl.pdf (reporting the institutions listed in Table 1 as owning about 55 percent of corporate equity, after excluding holdings of U.S. equity held by foreign residents). That number likely understates the percentage of institutional holdings, since the non-institutional "household" category, which acts as a default category, sweeps in hedge funds and not-for-profits which are not otherwise separately broken out. This removes another 6 percent from the household number that should best be included in the institution total. See $i d$. at 66 tbl.L.100 n.1 (noting that the household sector includes domestic hedge funds, private equity funds, and personal trusts). 
TABLE 1. Institutional Ownership of Equity in American Corporations

\begin{tabular}{lc}
\hline Type of Institutional Holder & $\begin{array}{c}\text { Equity Holdings (in billions } \\
\text { of dollars) }\end{array}$ \\
\hline Private Pension Funds & $\$ 2,517.3(15.6 \%)$ \\
State \& Local Pension Funds & $\$ 2,294.5(14.2 \%)$ \\
Mutual Funds (Including Closed End Funds) & $\$ 7,057.4(43.7 \%)$ \\
Exchange Traded Funds & $\$ 1,449.9(9.0 \%)$ \\
Insurance Companies & $\$ 2,134.3(13.2 \%)$ \\
Other (for example, Depository Institutions, & $\$ 701.5(4.3 \%)$ \\
Brokers/Dealers, Government's Outside Pension Plans & \\
\hline Total & $\$ 16,154.9$ \\
\hline
\end{tabular}

Source: FED. RESERVE BD., supra note 106 at 100 tbl.L.213 (after excluding holding of U.S. equity foreign residents).

The United States has long provided tax deferral treatment for money in retirement plans ${ }^{107}$ and employers have had multiple reasons to provide retirement benefits. ${ }^{108}$ But in post-World War II America, retirement policy, such as it was, did not center on investments in equity: social security was funded out of tax dollars, and employer-funded private pension plans were growing but looked to the corporation's cash flow for funding as much as to separate funds set aside and invested in equity investments. ${ }^{109}$ And institutions were a much smaller presence; in 1950, for

107. Government tax policy imposes no immediate tax liability on income earned in qualified plans, with individual beneficiaries only taxed upon their receipt of funds after retirement. I.R.C. $\S 401(\mathrm{k})$ (2012) (discussing cash and deferred arrangements). See also PETER J. WIEDENBECK, ERISA: PRINCIPLES OF EMPLOYEE BENEFIT LAW 212-15 (2010) (describing ERISA participation standards).

When income tax rates rise, this benefit to tax-deferred retirement plans becomes larger. See Kristian Rydqvist, Joshua Spizman \& Ilya Strebulaev, Government Policy and Ownership of Equity Securities 111 J. FIN. ECON. 70, 71 (2014) (showing the trend toward indirect ownership of stock and linking it to the incentive of higher marginal tax rates that push investors to hold assets in tax deferred vehicles).

108. Martin Gelter, The Pension System and the Rise of Shareholder Primacy, 43 SETON HALL L. REV. 909, 921-22 (2013) (positing that large employers introduced pension plans because unions and employees favored them when labor was scarce, since "generous pension plans were thought to secure union support of labor peace," with defined benefit plans creating an incentive to stay in the same firm until retirement).

109. In some other countries, retirement planning continues to rely more on these non-equity sources than in the United States. To the extent that the government is the primary source for worker retirement through current revenues and taxes, this institutional ownership of shares will not be present. 
example, institutions owned only about 6 percent of the total equity in American corporations. ${ }^{110}$

Regulatory funding requirements included in the Employee Retirement Income Security Act ("ERISA") in 1974, ${ }^{111}$ dramatically shifted this approach as Congress required employers to meet minimum funding levels and hold retirement monies in a separate trust fund. ${ }^{112}$ Pension fund assets skyrocketed ${ }^{113}$ and a large segment of these assets found their way into equities, which seemed to offer the best chance to generate the growth in returns necessary to pay temporally remote retirement obligations. ${ }^{114}$

The retirement plans in Table 1 divide into two groups-defined benefit plans and defined contribution plans-reflecting how retirement benefits accrue (and also leading to particular differences in incentives and conflicts that affect governance and voting as discussed in the next section). In a defined benefit plan, the employer sets aside money with a promise to pay a specified amount to employees during their retirement. ${ }^{115}$ In a defined contribution plan, the employer's retirement contribution each pay period goes into a separate account for each employee. Upon retirement, the employee would get as much or as little as the contributions had produced; thus, the risk of the market returns is on the shareholder and

See id. at 965 ("In the Continental European jurisdictions, public transfers (that is, public pensions) dominate.").

110. CONFERENCE BD., supra note 9, at 22 tbl.10, 27 tbl.13.

111. Pub. L. No. 93-406, 88 Stat. 829 (codified as amended in scattered sections of 26 and 29 U.S.C.). See Steven A. SASS, The Promise of Private Pensions: The First ONE Hundred Years 228 (1997) (discussing the enactment of ERISA and its effects).

112. 29 U.S.C. $\S 1053$ (requiring actuarial-determined annual payments and plans to pay down prior unfunded obligations).

113. The share of American GDP made up of pension assets has been between 42 and 47 percent over the last fifteen years, an increase from about 15 percent in 1975. See Christopher Chantrill, US Gross Domestic Product GDP History, US GOVERNMENT SPENDING, http://www.usgovernmentspending.com/us_gdp_history (last visited Aug. 18, 2014). Just in the 1980s, total pension fund assets increased 350 percent. CONFERENCE BD., supra note 9, at tbl.12 (showing an increase in pension fund assets from $\$ 871$ billion to $\$ 3.023$ trillion between 1980 and 1990).

114. See SASS, supra note 111, at 224-25; Gilson \& Gordon, supra note 13, at 880 ("Although plainly unintentional, the U.S. requirement - that a pension promise must be supported by assets held in trust rather than by a book entry on a corporate balance sheet--both generated and concentrated very large amounts of funds that would be invested in the capital markets by a class of fiduciaries on behalf of future retirees.").

115. Edward A. Zelinsky, The Defined Contribution Paradigm, 114 Yale L.J. 451, 455 n.5 (2004) (explaining the operation of defined benefit plan). Their dominance in retirement planning prior to ERISA is documented in MATTHEW P. FINK, THE RISE OF MUTUAL FUNDS: AN INSIDER'S VIEW 117 (2008) ("It cannot be emphasized too strongly that congressional draftsmen of ERISA were concemed almost exclusively with defined benefit ... plans ...."). 
not the company. ${ }^{116}$

Defined benefit plans, reflected in the first two lines of Table 1, include traditional company pension plans for their employees, ${ }^{117}$ plans established by state and local governments for their employees' retirement, ${ }^{118}$ and multi-employer plans in the unionized sector of the work force. ${ }^{119}$ Defined contribution plans are often invested in mutual funds, with employees usually being given a handful of specific fund altematives set out in the plan (based on employer-provided choices after negotiating with various fund providers). In each of these forms, shares are titled in the name of the retirement plan, which gives the plan the right to vote. ${ }^{120}$

ERISA accelerated a dramatic shift in retirement funding from defined benefit plans to defined contribution plans. ${ }^{121}$ Employer worries about fiduciary obligations written into ERISA and the employer's potential cash requirements if earnings on the defined benefit plan were insufficient to fund the benefits that had been promised, shifted plans toward the defined contribution format. ${ }^{122}$ By the end of the 2000 s, assets in defined contribution plans, which had been roughly equal to the amount in defined

116. Zelinsky, supra note 115 , at $458-61$.

117. In some high-profile American companies as late as the turn of the twenty-first century, most pension plan assets consisted of stock in the company itself; during the succeeding decade, and in the wake of scandals such as Enron, the mean share of company stock in plans declined by more than half from 19 percent to 5 percent See David Millon, Enron and the Dark Side of Worker Ownership, 1 SEATtLe J. SoC. Just. 113, 117-20 (2002); Alicia H. MunNell \& ANNIKa SundÉn, COMING UP SHORT: THE Challenge of 401(k) Plans 113 (2004).

118. Defined benefit plans invest in assets beyond equity and often have not made great use of equity. The California State Employees Pension System, for example, could not have invested more than 25 percent of its assets in equity until 1984. CAL. CONST. art. XVI, $\$ 17$ (repealed 1984) ("[T]he Legislature may authorize the investment of moneys of any public pension or retirement fund, not to exceed 25 percent of the assets of such fund determined on the basis of cost in the common stock or share ...."). See also Gelter, supra note 108, at 959 ("[M]any pension funds held few or no equities in their portfolios until the mid 1990s.").

119. See Labor Management Relations ("Taft-Hartley") Act section 302(c)(5), 29 U.S.C. § 186(c)(5)(B) (2012) (specifying equal representation of employers and employees on the board of union-run pension plans receiving payments from employers). See generally Stewart J. Schwab \& Randall S. Thomas, Realigning Corporate Governance: Shareholder Activism by Labor Unions, 96 MICH. L. REV. 1018, 1075-77 (1998) (describing the origin, structure and use of Taft-Hartley plans).

120. Cf. id. Employee Stock Ownership Plans, unlike pension plans, generally are not pooled investments and are required to provide pass-through voting to their participant. See 26 U.S.C. $\S 409$ (E)(2) (2012).

121. EDWARD A. ZELINSKY, THE ORIGINS OF THE OWNERSHIP SOCIETY: HOW THE DEFINED CONTRIBUTION PARADIGM CHANGED AMERICA 38-39 (2007) (describing how ERISA led the US down the path to a "defined contribution society").

122. See Gelter, supra note 108 , at 948 ("[ERISA] probably accelerated the trend toward more mobility, less firm-specific human capital, and possibly more general or industry-specific human capital."). 
benefit plans two decades earlier, were four times as large. ${ }^{123}$ Much of that new money was placed in mutual funds, ${ }^{124}$ which also included funds from self-employed workers as federal law extended tax-deferred status to Individual Retirement Accounts ("IRAs"). ${ }^{125}$

Retirement plans today hold at least half of funds invested in equity mutual funds and probably a good bit more. ${ }^{126}$ Individual investors also invest in mutual funds outside of their tax-favored retirement plans, attracted to the same low-cost way to gain diversification even without the tax deferral ${ }^{127}$ (although these non-retirement plan investments are more likely to be in non-equity mutual funds). ${ }^{128}$ Institutions also invest in mutual funds. Title to all these shares is in the name of the fund.

In Table 1, there are some other categories of institutional owners of equity that do not directly hold retirement funds, for example, insurance companies, depository institutions, and foundations, including those for college and university endowments. ${ }^{129}$ However, these institutions possess only a small minority of equity securities.

123. See id. at 924-25 figs.1-3 (graphing the reversal of positions of defined benefit plans and defined contribution plans).

124. FINK, supra note 115, at 132 ("It is impossible to overestimate the importance of [individual retirement accounts] and defined contribution plans to the mutual fund industry.")

125. Congress authorized self-employed individuals to establish tax-favored retirement plans then called Keogh plans in 1962 and expanded this favorable tax treatment multiple times in the decades that followed. Id. at 112-16. Federal regulations now permit individuals who have left their employers to roll over their funds in an IRA and preserve tax-deferred growth of their retirement savings, leading to growth of this segment of the market. See 26 U.S.C. $\S 72(t)(2)(A)(v)(2012)$ (permitting a tax-free rollover of an employee retirement benefit to an IRA).

126. See INV. Co. INST., 2013 INVESTMENT COMPANY FACT BOOK: A REVIEW OF TRENDS AND ACTIVITIES IN THE U.S. INVESTMENT COMPANY INDUSTRY 9 fig.1.1, 22, 25 fig.2.1, 133 (53d ed. 2013) [hereinafter ICI FACT BOOK 2013] (demonstrating that assets in mutual funds totaled \$13.045 trillion, and of that amount, one-third or roughly $\$ 4.3$ trillion was in domestic equity funds). Retirement plans' investment in domestic equity was $\$ 2.159$ trillion, or more than half of the amount invested in equity funds. Id. at 133 fig. 7.23 (providing the total amount of mutual fund retirement assets invested in equity). The retirement plans' portion of equity mutual funds is undoubtedly higher, since the computation above does not count retirement account assets in hybrid funds (about half of the size of mutual funds) which include a mix of equities and fixed-income securities including the bulk of target date and lifecycle funds. Id.

127. Portfolio theory, developed by financial economists over the last five decades, has shown diversified investments like a mutual fund can reduce risk as compared to non-diversified investments at a low cost, such that most investors prefer the built-in diversification of a mutual fund to creating their own diversified portfolio. See Gilson \& Gordon, supra note 13, at 885 (noting that households increasingly invest through diversification-providing intermediaries-mutual funds).

128. See ICI FACT BOOK 2013, supra note 126, at 134-36, 135 fig.7.24 (demonstrating college plans and annuities outside retirement plans).

129. There was a time when banks were a prime institutional holder of funds invested in equity, including estates and trust, but they now own only a portion of the small slice of equity owned by financial institutions, set out in Table 1. 
Two categories of institutional investors-asset managers and hedge funds-are not separately broken out in Table 1, but can be significant players in corporate governance. Asset management firms invest money from both individuals and institutions in a variety of asset categories, including exchange traded funds or alternative investments. For example BlackRock Institutional Trust Company, N.A., the largest asset manager in America, is the first- or second-largest shareholder in ExxonMobil, Microsoft, Apple, and General Electric. ${ }^{130}$ The multi-trillion dollars worth of assets under its management are split among different categories, with more than a trillion in mutual funds and a trillion managed for other institutional investors. ${ }^{131}$ Asset management can create another layer of intermediation for voting, with the asset manager serving as the owner of the shares, or as an agent for institutional clients investing money on behalf of individual beneficiaries.

Hedge funds include a variety of different entities pursuing a broad range of investment strategies, often taking higher risks to achieve aboveaverage market returns. While some of their investors are individuals investing their own money, two-thirds of hedge fund capital comes from institutional investors - $\$ 1.49$ trillion in 2012-and this segment is growing rapidly. ${ }^{132}$ What is relevant for our project is the subset of hedge funds whose strategy is to actively buy and sell equity, who we will call activist hedge funds. Equity investments for hedge funds, estimated to total $\$ 600$ billion, remain lumped in the default category of households in the government reports reflected in Table $1 .{ }^{133}$ Logically, as they should be included in the institutional data, Table 1 understates institutional ownership by that amount. ${ }^{134}$ Like asset managers, activist hedge funds

130. CONFERENCE BD., supra note 9, at 30-32.

131. See Gilson \& Gordon, supra note 13, at 886 n. 79 (presenting self-reported data disclosed on eVestment.com, a site providing data and analytical tools for investors); The Monolith and the Markets, ECONOMIST (Dec. 7, 2013), http:/www.economist.com/news/briefing/21591164-getting-15-trillionassets-single-risk-management-system-huge-achievement (reporting that passive investment products, such as exchange-traded funds, account for 64 percent of BlackRock's assets under management).

132. See Adam Brown, Institutional Investors to Boost Allocations to Hedge Funds, IR MAG. (May 16, 2013), available at http://www.irmagazine.com/articles/buy-side/19493/institutionalinvestors-boost-allocations-hedge-funds/ (referencing CITI PRIME FIN., INSTITUTIONAL INVESTMENT IN Hedge Funds: Evolving Investor Portfolio Construction DRIVEs Product CONVERgence, (June 2012) [hereinafter CITI PRIME FINANCE REPORT], available at http://www.citibank.com/ transactionservices $3 /$ homepage/demo/IIHF_June2012/.).

133. See supra note 106 for a discussion of hedge funds as being included within the default category of households in Table 1 , and not the category of institutions.

134. Hedge funds were not required to register with federal regulators until Dodd-Frank; that legislation blocks the public disclosure of data now collected. Reporting by Investment Advisers to Private Funds and Certain Commodity Pool Operators and Commodity Trading Advisors on Form PF, 
create an additional layer of intermediation - the hedge funds invest money from institutional investors, who in turn are investing funds received for the benefit of individual shareholders. Hedge funds hold title to the shares that they have purchased and vote them.

\section{Why Don't Most Intermediaries Care About Voting?}

Most institutions would often prefer not to vote. For example, the issue on the ballot, such as a Rule $14 \mathrm{a}-8$ social responsibility proposal, might not affect firm value, so that the institution's vote produces no benefit. $^{135}$ More generally, as John C. Coffee, Jr. has observed, the "expected gains from most governance issues are small, deferred, and received by investors, while the costs are potentially large, immediate, and borne by money managers."136

Consider the typical mutual fund's business model. These funds compete to become one of the retirement investment options that an employer presents to its workers. Applying modern portfolio theory, company retirement plans typically seek to provide their beneficiaries with options to create a diversified portfolio at a low cost. In choosing among the proffered investment options, individual beneficiaries focus on the relative performance of a particular fund as compared to alternative funds. They are likely to choose the fund that offers the best relative performance record.

From the fund's perspective, any monies spent on voting may reduce marginally the firm's relative performance compared to its competitors. ${ }^{137}$ Costs incurred to gather information and formulate an informed vote reduce the active fund's bottom line, while any benefits resulting from the vote can be realized by competitors holding the same stock who do not

Exchange Act Release No. IA-3308, 17 C.F.R. $\$ \S 275,279$ (Oct. 31, 2011), available at http://www.sec.gov/rules/fina1/2011/ia-3308.pdf.

135. Some institutions, for example labor-affiliated and state and local government pension funds, sponsor a disproportionate number of shareholder proposals, while other institutions sponsor few of those. See infra note 163 and accompanying text.

136. John C. Coffee, Jr., Liquidity versus Control: The Institutional Investor as Corporate Monitor, 91 ColuM. L. REV. 1277, 1328 (1991). See also Sanjai Bhagat \& Bernard Black, The NonCorrelation Between Board Independence and Long-Term Firm Performance 27 J. CORP. L. 231, 234 (2002).

137. Mutual funds are not likely to be a large percentage investor in any one company because exceeding 10 percent, for example, will eliminate their preferred flow through tax advantage and may open them to possible liability for insider trading. See Mark Roe, Political Elements in the Creation of a Mutual Fund Industry, 139 U. PA. L. REV. 1469, 1474-76 (1991) (describing the political reasons behind the tax framework for restricting a mutual fund's ownership of a company to 10 percent). 
incur voting costs. ${ }^{138}$ Mutual funds will prefer to focus on, "delivering lowcost, high-powered diversification and scale economies in active management... [which creates] significant problems in the efficient assignment of governance rights." ${ }^{139}$ In the words of Ronald J. Gilson and Jeffrey N. Gordon, mutual funds will be "rationally reticent," reluctant to invest resources in voting because at best it is irrelevant to getting business, and at worst it costs them business if they alienate any corporate plan sponsors who determine which mutual fund option to offer their beneficiaries. ${ }^{140}$

Defined benefit plans have better incentives to vote because their trustees know that any improved investment returns resulting from voting will reduce the amount that the sponsoring employer needs to contribute to fund the requisite payouts. These heightened voting incentives can be muted, at least for a private company, to the extent that bankruptcy potentially allows some firms to escape liability for their underfunded pension obligations.

Unlike mutual funds, state government pension funds do not compete for investment funds because state law mandates the flow of deposits into the fund and locks in deposited funds. As with other defined benefit plans, they have some incentives to use the vote so as to increase returns and thereby limit the amount that the particular governmental entity contributes. This incentive is muted if politicians can "kick the can" of underfunded pension liabilities down the road to the next generation of voters and taxpayers. ${ }^{141}$

Insurance companies also put money in equities to generate funds to pay distant claims. As with defined benefit plans, the insurer commits to pay a fixed amount at a future time in exchange for bearing the risk that its investment returns will cover those claims. Voting that increases investment returns is therefore beneficial.

138. Gilson \& Gordon, supra note 13 , at 890 (noting that "absolute performance will play a secondary role").

139. Id. at 895 .

140. Id.

141. Natalya Shnitser, Funding Discipline for U.S. Public Pension Plans: An Empirical Analysis of Institutional Design 9-11 (Sept. 1, 2013), available at http://papers.ssrn.com/sol3/papers.cfm? abstract_id=2151556 (unpublished manuscript) (describing how underfunding levels of pension plans varies with factors such as political control). See also Mark Peters, Pension Pinch Busts City Budgets, WALL ST. J. (Nov. 5, 2013, 6:05 PM), http:/online.wsj.com/news/articles/ SB10001424052702303471004579163602529729442 (discussing the effects of a current crisis in local and state funding of these plans). 
Even if the fund has an incentive to vote, managers who make decisions for the fund may have weak personal incentives to invest in voting to increase firm value. Partly this stems from government regulation. The Investment Advisers Act, for example, prevents the general use of incentive fee structures in mutual funds. ${ }^{142}$ Markets also have an effect: fund managers tend to be evaluated on metrics that can discourage an active use of voting. For example, The Big Short described how the managers of a German insurance company took a terribly timed long position on housing derivatives because they were being paid based on assets under management rather than based on performance. ${ }^{143}$

Overall, the result is that institutional investors prefer not to vote and are not activist shareholders. Company pension plans are the least active in corporate governance. ${ }^{144}$ Government employees' pension plans are relatively more active in voting, although their focus has been on more generic governance proposals and some specific social and political shareholder proposals. $^{145}$ Historically, insurance companies and foundations have been relatively less active in voting and corporate governance. Generally, mutual funds have been less active in voting and corporate governance issues than might be expected for a concentrated group owning 25 percent of equities in many large corporations, although in some instances they have worked with activist hedge funds. ${ }^{146}$

Activist hedge funds are different from the institutional investors because of their focus on corporate governance as an investment strategy. ${ }^{147}$ They typically acquire a sizeable equity position and seek to

142. Investment Advisers Act section 205, 15 U.S.C. $§ 80$ b-5(a)(1) (2012).

143. MICHAEL LeWIS, THE BIG SHORT: INSIDE THE DOOMSDAY MACHINE 200-19 (2011).

144. See, e.g., The Manhattan Inst.'s Ctr. for Legal Policy, 2013 Proxy Season Review, ProXY MONITOR, available at http://www.proxymonitor.org/Forms/2013Finding5.aspx ("As was the case in 2012 and throughout the 2006-13 period, only 1 percent of shareholder proposals in 2013 were introduced by shareholders without a tie to organized labor or a social, religious, or policy purpose.").

145. See Gretchen Morgenson, New Momentum for Change in Corporate Board Elections, N.Y. TIMES (July 6, 2013), http://www.nytimes.com/2013/07/07/business/new-momentum-for-change-incorporate-board-elections.html (including list of state plans supporting Harvard's shareholder rights project). They have also been more willing than other institutional investors to act as class representatives in shareholder litigation. Michael Perino, Institutional Activism Through Litigation: An Empirical Analysis of Public Pension Fund Participation in Securities Class Actions, 9 J. EMPIRICAL LEGAL STUD. 368, 375 (2012) (noting that public and union pension funds were listed as lead plaintiffs in 34.4 percent of filed cases).

146. See, e.g., Susanne Craig, The Giant of Shareholders, Quietly Stirring, N.Y. TimEs (May 18, 2013, http://www.nytimes.com/2013/05/19/business/blackrock-a-shareholding-giant-is-quietlystirring.html (noting that BlackRock, the largest shareholder in more than 1400 U.S. listed companies, has never sponsored a shareholder proposal).

147. Brav et al., supra note 12 , at 1749,1750 tbl.III, 1751 (providing data and analysis of the 
influence the board to change corporate policy: sometimes seeking to produce more cash quickly; ${ }^{148}$ other times engaging in merger arbitrage, ${ }^{149}$ or initiating a change in control transaction. ${ }^{150}$ Hedge funds identify governance initiatives where active monitoring might be valuable, which institutions can then decide to support with their voting power. ${ }^{151}$ Hedge funds are similar to other institutions, though, because they are the record owners for the shares they own, while the beneficial ownership accrues to the investors in the fund, creating the additional layer of agency costs in voting previously mentioned. ${ }^{152}$

\section{Government Responses to Weak Institutional Voting Incentives}

Voting in American democracy has always been voluntary, and citizens that fail to vote face at worst mild social ostracism. ${ }^{153}$ Not so for institutional investors who hold equity securities in corporations. In 1988, the Department of Labor ("DOL"), the agency responsible for administering and enforcing ERISA (and thus the regulator of defined benefit plans), declared that "the fiduciary act of managing plan assets which are shares of corporate stock would include the voting of proxies...." 154 Plan trustees or managers suddenly faced potential regulatory sanctions if they failed to vote shares their institutions held. In a later codification of this mandate, the DOL added that shareholder activism

is consistent with a fiduciary's obligations under ERISA where the responsible fiduciary concludes that there is a reasonable expectation that such monitoring or communication with management, by the plan alone or together with other shareholders, will enhance the economic

characteristics found in target companies of activist hedge funds).

148. See, e.g., CSX Corp. v. Children's Inv. Fund Mgmt. (UK) LLP, 654 F.3d 276, 279-81 (2d Cir. 2011) (describing efforts of shareholder investment funds to get the board of a railroad to implement policies providing more cash to shareholders).

149. See, e.g., William W. Bratton, Hedge Funds and Governance Targets, 95 GEO. L.J. 1375, 1423 (2007) ("The sixteen additional cases involve shareholder intervention respecting a single transaction. Such sideline input from Wall Street has been a fact of life in the acquisitions market for three decades, generated by merger arbitrageurs seeking to make sure the target gets sold at the maximum possible amount.").

150. See, for instance, the Dell transaction described supra note 5 and accompanying text.

151. Gilson \& Gordon, supra note 13, at 896-902.

152. There is a third level of agency costs created by hedge fund investing, as many institutions invest in hedge funds through funds of funds.

153. Voting is mandatory in some other countries. See Note, The Case for Compulsory Voting in the United States, 121 HARV. L. REV. 591, 592 (2007) (noting that twenty-four nations have compulsory voting in political elections).

154. Letter from Alan D. Lebowitz, Deputy Assistant Sec'y, Pension \& Welfare Benefits Admin. of the U.S. Dep't of Labor, to Helmuth Fandl, Chair of the Retirement Bd., Avon Products, Inc., 1988 WL $897696 * 2$ (Feb. 23, 1988). 
value of the plan's investment in the corporation, after taking into account the costs involved. ${ }^{155}$

In 2003, the SEC extended a similar rule to mutual funds, defined contribution plans, and other entities holding votes for the beneficial interests of others. ${ }^{156}$

Under these rules, an investment adviser has a fiduciary duty to vote stock using policies and procedures reasonably designed to ensure proxies are voted in the best interests of the clients. ${ }^{157}$ Both the DOL and SEC rules reflect agency cost concerns: agents who vote for beneficiaries may be failing to exercise a valuable part of the shareholder investment. Additional SEC regulations require mutual funds to disclose how they exercise the vote. $^{158}$

These regulations changed the pattern of voting, but enforcement remains weak. An Inspector General's report on the DOL program questioned its effectiveness, noting that few resources were devoted to it and that the DOL lacked authority to assess penalties for violations. ${ }^{159}$ Under the SEC rules, there was an enforcement action in $2009 .^{160}$

Separately, there has been a dramatic increase in the number of votes held. Rule $14 a-8$, promulgated in 1942 , has long permitted precatory votes on certain shareholder proposals. ${ }^{161}$ Today there are hundreds of these proposals every year, covering social responsibility issues and corporate

155. Interpretative Bulletin Relating to the Exercise of Shareholder Rights and Written Statement of Investment Policy Including Proxy Voting Guidelines, 29 C.F.R. $§ 2509.08 .2$ (Oct. 17, 2008), superseding 59 Fed. Reg. 32607 (June 23, 1994). The Bulletin also notes: "Plan fiduciaries risk violating the exclusive purpose rule [of economic value maximization for shareholders] when they exercise their fiduciary authority in an attempt to further legislative, regulatory or public policy issues through the proxy process."

156. Final Rule: Proxy Voting by Investment Advisers, Exchange Act Release No. IA-2106, 17 C.F.R. $\$ 275$ (Jan. 31, 2003) [hereinafter Investment Advisers Act Release], available at http://www.sec.gov/rules/final/ia-2106.htm.

157. See supra notes 154-156 and accompanving text.

158. See Rule 30b1-4 of the Investment Company Act of 1940, 17 C.F.R. $\S 270.30 \mathrm{~b} 1-4$ (requiring mutual funds to disclose their complete voting records annually, including portfolio securities they hold); Annual Report of Proxy Voting Record of Registered Management Investment Company (Form N-PX), available at https://www.sec.gov/about/forms/formn-px.pdf.

159. See U.S. DEP'T OF LABOR: OfFICE OF INSPECTOR Gen., Proxy-Voting MAY Not BE SOLELY FOR THE ECONOMIC BENEFIT OF RETIREMENT PLANS 2 (2011), available at http://www.oig.dol.gov/public/reports/oa/2011/09-11-001-12-121.pdf.

160. Intech Inv. Mgt. LLC, Exchange Act Release No. 1A-2872, 95 SEC Docket 2265 (May 7 , 2009), available at http:/www.sec.gov/litigation/admin/2009/ia-2872.pdf (regarding a fund that engaged a proxy advisory firm to vote proxies in accordance with AFL-CIO proxy recommendations in an effort to maintain and attract clients, but failed to disclose material conflict).

161. 17 C.F.R. $\$ 240.14 a-8$. 
governance concerns, such as the removal of staggered boards and poison pills. ${ }^{162}$ Furthermore, Dodd-Frank extended precatory shareholder votes to executive compensation (Say on Pay). ${ }^{163}$ As a result, shareholders vote on more issues than ever before and most institutional intermediaries are required to vote on all of them. ${ }^{164}$

\section{Responses from the Market: Proxy Advisory Firms}

The institutions' urgent need to be informed about these votes, and their lack of incentive to spend much money to do so, created an opening for a new set of agents in the voting process-proxy advisory firms that focus on providing information and voting services to institutional investors. These firms exploit economies of scale by collecting information about each of the votes held at public companies and then distributing them to each of the many institutional investors owning shares in that company. Their efficiencies extend to tracking and submitting the tens of thousands of votes cast each year by each institution. Moreover, these advisory firms have developed expertise on governance issues.

The cost of proxy advisory firms' services can be kept down by spreading them over many institutions that hold stock in companies in

162. See, e.g., The Manhattan Inst.'s Ctr. for Legal Policy, 2013 Proxy Season Scorecard, ProXY MONITOR, http://www.proxymonitor.org/ScoreCard2013.aspx (last visited Aug. 18, 2014)

163. Dodd-Frank Wall Street Reform and Consumer Protection Act (“Dodd-Frank”), Pub. L. No. 111-203, $\S 951,124$ Stat. 1375, 1899 (2010) (adding new section 14A to the Securities Exchange Act of 1934). Ancillary regulatory changes, such as the New York Stock Exchange's elimination of brokers' freedom to vote undirected shares for their clients in uncontested elections, have further enhanced the voting role of institutional shareholders. See David A. Katz \& Laura A. MacIntosh, A Seismic Shift in Mechanics of Electing Directors, N.Y.L.J., July 27, 2006, at 5 (describing the change as a "massive shift of voting power from brokers to institutions").

164. In 2013, two commentators suggested that "[t]he SEC should reconsider the entirety of the shareholder voting process, including the mandate that institutional investors participate in all corporate votes." David F. Larcker \& Allan L. McCall, Proxy Advisers Don't Help Shareholders, WaLL ST. J. (Dec. 8, 2013, 6:51 PM), http://online.wsj.com/news/articles/SB1000142405270230349780457924184 2269425358. While a full examination of this issue lies outside the scope of this Article, we note several potential problems with their approach. First, as we noted above, there is a collective action problem in the provision of shareholder monitoring that the government's voting mandate solves: eliminating the mandated vote would result in suboptimal levels of shareholder monitoring. Second, if institutional investors choose not to participate in the voting process, several practical problems are likely to develop. For example, companies may no longer be able to obtain quorums at their annual meetings for the conduct of routine business. In addition, the absence of institutional investors from voting would increase the relative voting power of shareholders that have noneconomic interests, such as the sponsors of many social responsibility proposals under Rule 14a-8. Third, to the extent that institutional shareholders do not calculate the long-term value effects of voting on certain matters, they may fail to support proposals that increase firm value in the long run. The current government mandate requires them to make these determinations. 
which similar issues will arise. ${ }^{165}$ Institutional investors have noticed: as TIAA-CREF, one of the largest institutional investors, stated, "Though we dedicate a significant amount of resources to corporate governance research and the voting of proxies, we still would have difficulty processing the 80,000 plus unique agenda items voted by our staff annually without utilizing [proxy firm] research."166

A small group of proxy advisory firms that sells information about corporate voting as well as voting recommendations to institutional investors has grown up over the last twenty-five years. ${ }^{167}$ The origins of the industry were in the corporate governance movement of the $1980 \mathrm{~s}$, spurred at times by profit opportunities and enhanced by the regulatory changes just discussed. Institutional Shareholder Services is the oldest, best-known proxy advisory firm, and has the largest current client base. One of its founders, Robert Monks, had been an administrator of the DOL's ERISA program prior to the founding of ISS and was a key player in the development of the DOL's decision to treat proxy voting as a plan asset. ${ }^{168}$ It has 1100 clients, including most of the largest mutual funds, and offices in the U.S. and around the globe. ${ }^{169}$ In addition to its advice on proxy voting, it has a large consulting business advising clients on governance issues. ${ }^{170}$

165. See BEW \& FIELDS, supra note 17, at 1-2.

166. Comment Letter from Jonathan Feigelson, Senior Vice President, Gen. Counsel \& Head of Corp. Governance, Teachers Ins. \& Annuity Ass'n of Am. \& College Retirement Equities Fund ("TIAA-CREF") to Elizabeth M. Murphy, Sec'y, U.S. Sec. \& Exch. Comm'n, On Concept Release on the U.S. Proxy System in Release No. 34-62495, at 5 (Nov. 8, 2010), available at http://www.sec.gov/comments/s7-14-10/s71410-263.pdf.

167. This has been described as "a classic oligopoly structure" in an earlier version of a paper by David Larcker, Allan McCall, and Gaizka Ormazabal. David F. Larcker, Allan L. McCall \& Gaizka Ormazabal, Proxy Advisory Firms and Stock Option Repricing 2 n.6 (Rock Ctr. for Corporate Governance, Working Paper No. 100, Apr. 9, 2012), available at http://papers.ssrn.com/sol3/ papers.cfm?abstract_id=1811130\# (subsequently published as David F. Larcker, Allan L. McCall \& Gaizka Ormazabal, Proxy Advisory Firms and Stock Option Repricing, 56 J. ACCT. \& ECON. 149 (2013)).

168. Robert Monks and ISS co-founder Nell Minow also formed Lens, Inc., an early entry in activist investment. Minnow said "We wanted to be a critic on the stage rather than in the audiencethe kind of entity that organizations like the ISS and the IRRC write about." Lucy Alexander, Profile: Nell Minow, IR MAG. (Feb. 1, 1997), http://www.irmagazine.com/articles/people-careers/17680/profilenell-minow/. More recently Monks and Minow have run GMI Ratings, a firm that focuses not on proxy recommendations but on ratings more generally, including governance metrics.

169. About ISS Corporate Services, ISS CORPORATE SERVICES, http://www.isscorporateservices.com/about (last visited Aug. 19, 2014). ISS was sold to private equity firm Vestar Capital Partners in 2014, its third ownership change in seven years. Liz Hoffman, Vestar to Buy ISS for \$364 Million, WALL ST. J., (Mar 18, 2014, 5:19 PM), http://online.wsj.com/news/articles/ SB10001424052702304017604579447013092286156.

170. This consulting business has generated some concerns about potential conflicts of interest. 
Glass, Lewis \& Co., LLC's ("Glass Lewis") recent growth has made it a very visible number two. ${ }^{171}$ It grew up after the SEC's 2003 expansion of the voting obligations of mutual funds and has been owned since 2007 by the Ontario Teachers' Pension Plan, itself an institutional investor. ${ }^{172}$ Glass Lewis has doubled its client base over the last half-decade, in part through its 2010 acquisition of PROXY Governance. ${ }^{173}$

Proxy advisory firms have acquired an aura of great influence in proxy voting, but their power may be overstated. ISS gained early prominence for its perceived influence in the bitterly fought Hewlett-Packard acquisition of Compaq in 2002. ${ }^{174}$ Corporations have complained about ISS's power, citing anecdotal evidence that many shareholders vote immediately after ISS makes a recommendation. ${ }^{175}$ Several academic studies show a $15-$

See infra Part II.B.2.

171. Ross Kerber, For Glass Lewis, More Proxy Clout Means More Heat, CHI. TRIB. (June 13, 2012), http://articles.chicagotribune.com/2012-06-13/news/sns-rt-corporate-governanceglasslewis 11 e8h763g-20120613_1_proxy-adviser-iss-clients (noting that in nine years Glass Lewis had gone from a start-up to the chief rival of ISS).

172. In 2013, it sold 20 percent to another Canadian institutional investor, AIMCo. Press Release, Ont. Tchr. Pension Plan, Teachers' Sells 20\% Stake in Glass Lewis to AIMCo (Aug. 28, 2013), available at http://www.otpp.com/news/article/-/article/697097.

173. Press Release, Glass, Lewis \& Co., LLC, Glass Lewis Announces Agreement with PGI (Dec. 20, 2010), available at http://www.glasslewis.com/about-glass-lewis/press-releases/. Smaller segments of the market are held by Egan-Jones, owned by the Egan Jones Rating Agency, Inc., and Marco Consulting Group, which has focused on advising Taft-Hartley firms.

174. Luisa Beltran, ISS Could Kill HP-Compaq, CNN MONEY (Mar. 4, 2002, 4:02 PM), http://money.cnn.com/2002/03/04/deals/iss_hp/index.htm ("A little known but very influential proxy advisory firm could kill Hewlett-Packard Co.'s chances to succeed in its $\$ 22$ billion takeover ...."). But see Luisa Beltran, ISS Backs HP-Compaq Merger, CNN.COM (EUROPE) (Mar. 5, 2002, 9:01 PM), available at http://premium.europe.cnn.com/2002/BUSINESS/03/05/iss.hp/ ("Institutional Shareholder Services issued an opinion late Tuesday backing Hewlett-Packard Co.'s $\$ 22$ billion takeover of Compaq Computer Corp.").

175. A comment letter from Douglas K. Chia, Assistant General Counsel and Corporate Secretary of Johnson \& Johnson, demonstrates that the number of shares voted within one business day after an ISS report (and voted in accordance with the ISS recommendation) was more than four times larger than the average shares voted per day during the five business days before the ISS report was published. See Comment Letter from Douglas K. Chia, Assistant Gen. Counsel \& Sec'y, Johnson \& Johnson, to Elizabeth M. Murphy, Sec'y, U.S. Sec. \& Exch. Comm'n, on Concept Release on the U.S. Proxy System in Release No. 34-62495 at 2 (Oct. 19, 2010), available at http://www.sec.gov/comments/s714-10/s71410-115.pdf.

A comment letter from IBM's vice president noting a similar pattern of voting emphasized that the IBM voting bloc essentially controlled by ISS has more influence on the voting results than IBM's largest shareholder. And this voting block is controlled by a proxy advisory firm that has no economic stake in the company and has not made meaningful public disclosure about its voting power, conflicts of interest or controls.

Comment Letter from Andrew Bonzani, Vice President, Assistant Gen. Counsel \& Sec'y, IBM, to Elizabeth M. Murphy, Sec'y, U.S. Sec. \& Exch. Comm'n, on Concept Release on the U.S. Proxy System in Release No. 34-62495 at 3 (Oct. 15, 2010), available at http://www.sec.gov/comments/s714-10/s71410-84,pdf. 
30 percent correlation of shareholder voting with proxy advisory recommendations. ${ }^{176}$ James Cotter, Alan Palmiter, and Randall Thomas found that mutual funds tend to vote in line with ISS recommendations and follow them more consistently than they do management recommendations. ${ }^{177}$

However, these correlations do not establish a causal link between the outcome of a shareholder vote and an ISS recommendation. ISS develops its policies in conjunction with its institutional clients, and during this process clients give input to ISS about their views on corporate governance issues, leading some academics to discount the independent effect of ISS's recommendations. ${ }^{178}$ Even so, Yonca Ertimur, Fabrizio Ferri, and David Oesch suggest some portion of voting results can be attributed to the advisory firm. ${ }^{179}$

Some large institutional advisers have said they do not use proxy advisory firms. BlackRock's head, for example, wrote:

Companies that focus only on gaining the support of proxy advisory firms risk forgoing valuable and necessary engagements directly with shareholders.... We reach our voting decisions independently of proxy advisory firms on the basis of guidelines that reflect our perspective as a fiduciary investor with responsibilities to protect the economic interests of our clients. ${ }^{180}$

Other institutions use proxy advisers only for information collection. The Council of Institutional Investors ("CII") noted that nine of its ten largest member funds do not delegate voting decisions to a proxy adviser, using instead their own voting guidelines. However, the CII supports their use, stating that, "without proxy advisers, many pension plans-

176. See infra notes 178-179. See generally KENNETH L. ALTMAN \& JAMES F. BURKE (THE AltMAN GROUP), PROXY ADVISORY FIRMS: THE DEBATE OVER CHANGING THE REGULATORY FRAMEWORK (Mar. 1, 2011), available at http://astfundsolutions.com/pdf/TAGSpecRptProxyAdv.pdf (providing summary and analysis of comments submitted to the SEC regarding the influence of proxy advisory firms on the proxy voting process).

177. James Cotter, Alan Palmiter \& Randall Thomas, ISS Recommendations and Mutual Fund Voting on Proxy Proposals, 55 VILL. L. REV. 1, 2 (2010). But see Peter Iliev and Michelle Lowry, Are Mutual Funds Active Voters? (Apr. 15, 2014), available at http://papers.ssrn.com/sol3/ papers.cfm?abstract_id=2145398 (unpublished manuscript) (arguing that many mutual funds place relatively little weight on proxy advisory services' voting recommendations).

178. Stephen Choi, Jill Fisch \& Marcel Kahan, The Power of Proxy Advisors: Myth or Reality?, 59 EMORY L.J. 869, 906 (2010) (suggesting that many overemphasize the influence of ISS and estimating that its report shifts 6-10 percent of shareholder votes as opposed to figures of up to onethird in some other analyses).

179. Ertimur, Ferri \& Oesch, supra note 11 , at $979-80$ (using the difference between voting behavior of block and non-block institutional holders to suggest a floor of causation).

180. Craig, supra note 146 , at 2 . 
particularly smaller funds with limited resources-would have difficulty managing their highly seasonal proxy voting responsibilities for the thousands of companies in their portfolios." 181

In sum, proxy advisory firms help their clients to lower their cost of informed voting and to address collective action problems. They also have some degree of influence over voting outcomes and suffer some conflicts of interest. ${ }^{182}$

\section{B. CONFLICTS OF INTEREST OF INSTITUTIONAL INTERMEDIARIES, PROXY ADVISORY FIRMS, AND HEDGE FUNDS}

Conflicts of interest may lead institutional investors, hedge funds, and even proxy advisory firms to cast votes to further their own interests at the expense of their beneficiaries. ${ }^{183}$ When this happens, institutions may not be voting to maximize shareholder value, and our theory of corporate voting - which assumes that shareholders vote to maximize firm valuewill be undercut. In this section, we identify three significant types of conflicts and potential policy solutions for each of them.

\section{Institutional Investor Conflicts}

Institutional investors' conflicts of interest vary by investor category. For example, the three types of defined benefit plans - corporate pension plans, state and local government pension plans, and multi-employer plans in the unionized sector-have distinct sets of conflicts. In private pension plans, company management picks the trustee who operates the plan, and the trustee selects the outside managers that actually invest its capital. Both are likely to want to please those who have appointed them, ${ }^{184}$ especially if the plan holds a large block of the company's stock. These ties of the plan's managers to company managers could affect voting. For example, corporate pension plans may oppose shareholder initiatives to change governance at other companies with a mentality of "There but for the grace of God go I."

181. Comment Letter from Council of Institutional Investors, supra note 19, at 5 .

182. We explore these conflicts more fully in Part II.B.2.

183. Jill Fisch, Securities Intermediaries and the Separation of Ownership from Control, 33 SEATTLE U. L. REV. 877, 887 (2010) ("Institutional intermediaries and their decision-makers hold a variety of complex economic interests that challenge their incentive to maximize firm value.").

184. See, e.g., Investment Advisers Act Release, supra note 156, $\S$ I ("An adviser may have a number of conflicts that can affect how it votes proxies. For example, an adviser (or its affiliate) may manage a pension plan, administer employee benefit plans, or provide brokerage, underwriting, insurance, or banking services to a company whose management is soliciting proxies. Failure to vote in favor of management may harm the adviser's relationship with the company."). 
In government pension plans, those who run the plan may have a different type of conflict. The fund trustees are often elected officials or political appointees. For example, the New York City Comptroller, an elected official, controls NYCERS, a large pension plan for city employees. ${ }^{185}$ The political ambitions of the trustees may lead them to cast votes to further their political objectives at the expense of pension plan beneficiaries. As a result, these public sector funds may be more involved in broader public policy issues, such as supporting social investments. ${ }^{186}$ Outright corruption, or pay to play, is possible as well if prospective fund managers and their proxy advisory firms use political contributions to gain favor with those elected officials who allocate investment responsibilities at these entities.

Labor-affiliated multi-employer pension plans must have "balanced" boards of management and union representatives, but management's trustees often cede authority for investment decisions to union trustees. ${ }^{187}$ The union trustees must balance the labor-organizing motives of unions and their members' desire for improved wages and working conditions against the more capitalist concern of generating higher returns to provide for employees' future retirement benefits. ${ }^{188}$ In the $1990 \mathrm{~s}$, union-affiliated pension plans became more active in governance as to shareholder proposals. ${ }^{189}$

Mutual funds' conflicts stem from employers' choices about which

185. The plans for California employees and teachers also have or have had elected officials in management roles. See Fisch, supra note 183 , at 883 .

186. Id. at $881-82$.

187. Management trustees are largely concerned with the size of their company's contributions to the plan. These payments tend to be a fixed amount, so that these trustees have little incentive to get further involved. See Schwab \& Thomas, supra note 119, at 1077 ("Despite the balanced board membership, unions have tended to dominate these jointly managed funds. Indeed, it is '[o]ften ... very difficult to distinguish between the pension fund and the union.' One reason is that the union pension funds have typically been funded through fixed contributions by the employer with the trustees of the fund setting the pension levels. Whether the pension does well or poorly on its investment of such funds does not impact the employer directly.").

188. Gelter, supra note 108 , at $910-11$ (describing labor's shift toward more shareholder friendly policies as focus has moved from wealth created by human capital to wealth created by financial capital). See also David F. Larcker \& Brian Tayan, Union Activism: Do Union Pension Firms Act Solely in the Interests of Beneficiaries?, STANFORD CLOSER LOOK SERIES 1-3, 5 Ex.1 (2012) (discussing pension fund shareholder activism), https://www.gsb.stanford.edu/sites/default/files/ 30_UnionActivism.pdf.

189. Schwab \& Thomas, supra note 119, at 1080. See also Richard Trumka, Multiemployer Pension Plans, PLANSPONSOR MAG., Feb. 1998, available at http://www.plansponsor.com/ MagazineArticle.aspx id $=6442461269$ (noting that multiemployer plans used voting rights to pursue corporate governance proposals). 
options to provide employees in their tax-favored retirement plans. ${ }^{190}$ Employers can choose from a wide variety of funds and fund managers and are loath to cast votes that might cause employers to cut off their access to employees' retirement money. ${ }^{191}$ Offsetting these worries is the fact that the most successful fund families now control more than 70 percent of the market for retirement plans, ${ }^{192}$ and these large funds know that the retention of any one company's business is less critical to the fund's overall success.

SEC rules requiring policies and procedures by investment advisers to show shares are voted in the best interest of plan beneficiaries specify that such policies and procedures must explain how the fund resolves material conflicts of interest. ${ }^{193}$ The SEC's release accompanying the rules lists various means advisers might use to ensure proxy votes are voted in the client's best interest, including basing votes on a predetermined policy, or basing votes on a predetermined policy based on recommendations of an independent third party such as a proxy advisory firm. ${ }^{194}$

Our theory assumes that institutions can overcome their conflicts of interest and cast their proxies to maximize the value of the firm. Chinese walls, such as those described below for ISS, ${ }^{195}$ can be a productive addition in institutions as well. The SEC's rules and regulations provide a strong foundation for ensuring that occurs if they are adequately enforced, although the relatively small number of enforcement actions noted in Part II.A.3 suggests there is room for a broader impact.

\section{Proxy Advisory Firms' Conflicts}

Proxy advisory firms' perceived influence has led to close scrutiny of their operations. In a 2010 concept release, the SEC raised the issue of whether proxy firms should be subject to regulatory oversight, as they influenced voting at firms in which they had no economic stake. ${ }^{196}$ Large

190. Jill E. Fisch, Rethinking the Regulation of Securities Intermediaries, 158 U. PA. L. REV. 1961, 2003-04 (2010) (describing alternatives chosen by plan providers).

191. See Marcel Kahan \& Edward B. Rock, Hedge Funds in Corporate Governance and Corporate Control, 155 U. PA. L. REV. 1021, 1055-56, n.170 (2007) (quoting John Bogle, founder and former head of Vanguard, who noted that merely voting against management could "jeopardize the retention of clients of $401(k)$ and pension accounts.").

192. Gilson \& Gordon, supra note 13 , at 886, n.78.

193. For a further explanation of these rules, see supra Part II.A.3.

194. Investment Advisers Act Release, supra note 156, § II.A.2.b.

195. See infra Part II.B.2. A Chinese wall is an information barrier within a firm to prevent an exchange of information that could raise conflict questions.

196. U.S. Proxy System Concept Release, supra note 18. No action has been taken on this proposal. The SEC's Division of Investment Management issued a staff legal bulletin in 2014 requiring 
corporate issuers and prominent corporate lawyers have raised similar concerns. ${ }^{197}$ Critics have also complained about a lack of transparency in how proxy advisory firms determine their voting recommendations, possible conflicts of interest when advisory firm employees serve on boards of companies that the adviser is rating, and the potential political biases of those running the advisory firms. ${ }^{198}$

Actual business conflicts are another issue. In particular, ISS has a separate consulting business on voting issues that is marketed to issuers. Issuers that purchase those services may improve their chances of getting a favorable recommendation from ISS on an important issue. The SEC's 2010 concept release suggested it might further examine proxy firm disclosures to determine if they "adequately indicate[] to shareholders the existence of a potential conflict with respect to any particular proposal."199 ISS has taken steps to wall off that part of the business from advisory recommendations; a Government Accountability Office study reports that most ISS clients are satisfied with the steps it has taken in that regard. ${ }^{200}$

For our purposes, it is important that ISS provide voting information and recommendations that assist shareholders in voting to maximize firm value. Full disclosure of its voting recommendation methodology and placement of Chinese walls between its voting advisory services and its corporate consulting branch are important ways to help ensure this happens. Of course, we can also rely upon corporate management to aggressively point out any persistent conflicts of interest.

\section{Hedge Fund Conflicts: Empty Voting}

Hedge funds, because of their activist nature and sophisticated financial strategies, may put themselves in conflicted voting positions.

proxy advisers to affirmatively disclose "significant relationships" or "material interests" that may pose a conflict of interest when they advise clients. Sec.\& Exch. Comm'n, Div. of Inv. Mgmt., Staff Legal Bulletin No. 20 (IM/CF) (June 30, 2014), http://www.sec.gov/interps/legal/cfslb20.htm.

197. See BEW \& FIELDS, supra note 17, at 6-7 ("In their comments in response to the SEC's concept release on the proxy industry review, corporate issuers called out specific instances in which proxy adviser recommendations seemed to dramatically affect voting.").

198. James R. Copeland, Politicized Proxy Advisers vs. Individual Investors: Institutional Shareholder Services' Ballot Advice Often Clashes with the Desires of the Average Diversified Investor, WALL ST. J. (Oct. 7, 2012, 7:06 PM), http://online.wsj.com/article/SB100008723963904446201 04578012252125632908.html.

199. U.S. Proxy System Concept Release, supra note 18, at 120. That same SEC proposal also raises the possibility of requiring proxy advisory firms to register as investment advisers. Id. $\S \mathrm{I}$.

200. U.S. GOV'T ACCOUNTABLITY OFFICE, GAO-07-765, CORPORATE SHAREHOLdER MEETINGS: ISSUES RELATING TO FIRMS THAT ADVISE INSTITUTIONAL INVESTORS ON PROXY VOTING 10-11 (2007), available at http://www.gao.gov/products/GAO-07-765. 
Funds employ various hedging techniques that can eliminate their financial stake in a firm while still retaining voting rights, employing what is commonly referred to as "empty voting." 201 The most notorious example of this phenomenon occurred during Mylan Laboratories' ("Mylan") acquisition of King Pharmaceuticals ("King") by a merger form that required a vote by Mylan shareholders. ${ }^{202}$ Richard Perry's hedge fund, Perry Capital, held shares in King and was anxious to have the deal consummated. The market viewed the acquisition as bad for Mylan but good for King, and some Mylan shareholders-led by Carl Icahn with a 9.9 percent stake-threatened to vote against the merger.

In response, Perry Capital accumulated a 9.9 percent stake in Mylan and simultaneously entered into derivative contracts which hedged its financial exposure to Mylan stock while retaining the stock's voting rights. It was then in a position to vote those shares in the Mylan merger election. ${ }^{203}$ The parties' termination of the deal after King announced an earnings restatement mooted the vote, ${ }^{204}$ but the point had been madesophisticated financial techniques can be employed to separate voting rights from financial interest and severely undercut the efficacy of shareholder voting.

Alternative transactions raise similar conflicts outside of a takeover context. In CSX Corp. v Children's Investment Fund Management (UK), ${ }^{205}$ a hedge fund, trying to avoid disclosure requirements, entered into total return equity swaps based on CSX Corp. ${ }^{206}$ Its counterparties were banks performing market-making services to a client for a fee. To cover their potential exposure if their side of the swap generated liability, the banks bought an equivalent number of CSX shares. The result was that the banks

201. Brav et al., supra note 12 , at 1748 . The term "empty voting" was coined in Henry T.C. Hu \& Bemard Black, The New Vote Buying: Empty Voting and Hidden (Morphable) Ownership, 79 S. CAL. L. REV. 811, 815 (2006). We will be using the term in a somewhat more specific to way to refer to the voting of shares whose economic value has been hedged-what $\mathrm{Hu}$ and Black would refer to as negative economic ownership. Id. at 815 .

202. Frank Partnoy \& Randall Thomas, Gap Filling, Hedge Funds, and Financial Innovation, in NEW FINANCIAL INSTRUMENTS AND INSTITUTIONS: OPPORTUNITIES AND POLICY CHALLENGES 101, 126-27 (Yasuyuki Fuchita \& Robert E. Litan eds., 2007).

203. Hu \& Black, supra note 201, at 825 .

204. Drug Firms Abandon Transaction, N.Y. TIMES (Feb. 28, 2005), http:/query.nytimes.com/gst/fullpage.html?res=950DE7D9153DF93BA15751C0A9639C8B63.

205. CSX Corp. v. Children's Inv. Fund Mgmt. (UK) LLP, 562 F. Supp. 2d 511 (S.D.N.Y. 2008) affd, 292 F. App'x 133 (2d Cir. 2008) and aff'd in part, vacated in part, remanded, 654 F.3d 276 (2d Cir. 2011).

206. For a nice explanation of total retum equity swaps, see CSX Corp., 562 F. Supp. 2d at 51921. 
were now empty voters in the CSX Corp: they owned the shares but held none of the financial risk.

Empty voting has been available for some time. By holding shares in a corporation while simultaneously selling them short, an investor can retain a vote in the corporation yet still benefit from a decline in the price of the stock. This possibility has grown with the expansion of sophisticated securities derivatives markets, and includes the equity swaps mentioned above. Such transactions have the potential to completely separate voting rights from the economic interest in the corporation and represent a real threat to the basis of the shareholder franchise. ${ }^{207}$

We should emphasize that this is not a principal-agent problem between the hedge funds and their investors, as empty voting benefits the investors in the hedge fund. It can, however, lead to a vote that does not maximize firm value so as to threaten the foundation of our justification for a shareholder vote: that the shareholders have a unique interest in increasing the share price. If a hedge fund actually has an interest in lowering the share price, then our theory would suggest they should not have a vote at all.

Our theory suggests that empty voting is not a legitimate exercise of the franchise and should be banned. As a practical matter, there do not appear to have been a large number of American cases since the Mylan episode. Additionally, it may be too costly to enforce such a ban because of the line drawing problems inherent in defining empty voting, and the sophistication of the derivatives market will make it difficult to determine when it occurs. ${ }^{208} \mathrm{~A}$ mix of disclosure and limitation is a second-best option in such a setting, ${ }^{209}$ but we acknowledge empty voting could undercut the effectiveness of shareholder voting. ${ }^{210}$

207. For some examples of empty voting, see Henry T.C. Hu \& Bernard Black, Empty Voting and Hidden (Morphable) Ownership: Taxonomy, Implications, and Reforms, 61 BUS. LAW. 1011, 1024-37 (2006); Hu \& Black, supra note 201, at 828-36; Shaun Martin \& Frank Partnoy, Encumbered Shares, 2005 U. ILL. L. REV. 775, 809-11.

208. In a recent court case, Henry $\mathrm{Hu}$ and Bernard Black, authors of some of the original papers on empty voting, saw themselves on opposite sides of the question of whether it had occurred. For a discussion of this case, see Frank Partnoy, U. S. Hedge Fund Activism, in RESEARCH HANDBOOK ON SHAREHOLDER POWER 29-32 (Jennifer G. Hill \& Randall S. Thomas, eds.) (forthcoming 2014) (on file with author).

209. Id. at 21. See also Hu \& Black, supra note 201, at 875-85, 899-901 (discussing a proposal for integrated ownership disclosure and limits on voter rights); Hu \& Black, supra note 207, at 104755,1057 (same).

210. For a broader point about how limitations in the technology of voting should lead to less use of voting, see Marcel Kahan \& Edward B. Rock, On Improving Shareholder Voting: An Esscy for D Daniel Prentice, in RATIONALITY IN COMPANY LAW: ESSAYS IN HONOUR OF DD PRENTICE 257, 262- 


\section{APPLYING OUR VOTING THEORY IN THE WORLD OF INTERMEDIARY CAPITALISM}

Having analyzed the challenges that weak incentives to vote and conflicts of interest pose to our theory, as well as potential solutions to them, we now use our theory to analyze two applications of corporate voting's role today. Part III.A examines high-dollar immediate-value votes, that is, a shareholder vote that has a clear, immediate impact on the firm's stock price. Hedge funds often push for these votes when the transactions can translate directly into investment gains. Here, shareholders can have a relative advantage as a decisionmaker when boards and management are conflicted or captured. Two important examples are shareholder votes on proposed merger transactions, especially in management buyouts, and contested elections of directors, both control contests and short slate contests.

Part III.B looks at voting when the outcome will only have a small or negligible immediate dollar impact on the corporation's stock price, but is likely to affect the long-term value of the firm. In these instances, hedge funds are unlikely to lead shareholder opposition because the immediate payoffs are too low to attract their attention. These shareholder votes may also serve to monitor conflicts of interest or board capture situations, such as interested transactions between directors and the corporation, or decisions relating to executive compensation. In this situation, a shareholder vote might be appropriate if: (1) managers' actions affect the current stock price or long-term value of the company; (2) potential or actual conflicts of interest exist; and (3) there are systemic benefits that will be realized by all shareholders if the costs of monitoring these conflicts are less than the benefits. We examine Say on Pay advisory votes on executive compensation as an example of this situation.

\section{A. High-Dollar IMMEDiate-VALUE MONITORING Situations}

When there is an immediate significant impact on a firm's stock price from shareholder voting, and management is conflicted or captured, shareholders have strong incentives to vote. But the proponents of a shareholder initiative, or the leaders of shareholder opposition to management proposals, must shoulder the full costs of their actions and will only capture their pro rata share of any gains that may result. As a result, many shareholders will be reluctant to initiate activism, although they are willing to free-ride on the efforts of others. Institutional investors 
are "rationally reticent," 211 waiting for someone to lead them in voting activism.

The new prominence of shareholder voting in this context reflects the interaction of several actors. First, the organization and regulation of, and business plans followed by, hedge funds give them high-powered incentives to seek out governance changes that produce immediate payoffs for shareholders. Second, groups of hedge funds, known as wolf packs, magnify this effect, while providing some diversification benefits for individual funds. Third, other investors, particularly mutual funds, who are unwilling to initiate voting initiatives, are willing to vote for at least some of the initiatives put forward by the hedge funds. Fourth, the growing inflow of institutional fund money into hedge funds magnifies the prior effect. Finally, hedge funds effectively lobby proxy advisory firms so as to increase their yield from the institutional investor vote.

\section{Hedge Funds Lead Voting Activism in High-Dollar Situations}

Hedge fund shareholder activists are good candidates to take the leadership role. Today, over one hundred hedge funds are engaged in activism and led over 300 interventions at major American companies in 2013. ${ }^{212}$ Several characteristics of hedge funds make them well suited to act as leaders in shareholder voting, and more generally, corporate governance activism. First, hedge fund managers have more powerful incentives to seek out return-generating transactions than other institutional investors. Their income is largely performance based, usually including a performance fee of 15-20 percent of portfolio profits ${ }^{213}$ in addition to a management fee of 1-2 percent of assets under management. ${ }^{214}$ Thus, successful activism can generate enormous personal benefits to these managers.

211. Gilson \& Gordon, supra note 13 , at 917.

212. Martin Lipton, Dealing With Activist Hedge Funds, CLS BLUE SKY BLOG (June 21, 2013), http://clsbluesky.law.columbia.edu/2013/06/21/dealing-with-activist-hedge-funds/ ("The 2013 proxy season saw a continuance of the high and increasing level of activist campaigns experienced during the last ten years. There have been more than 300 activist attacks on major companies during this period."); Marty Lipton, Karessa L. Cain \& Sabastian V. Niles, Lessons from the 2013 Proxy Season, CONF. BD. GOVERNANCE CENTER BLOG (June 10, 2013), http://tcbblogs.org/governance/2013/06/10/lessons-fromthe-2013-proxy-season/ (reporting that in 2013, "[s]hareholder activism [was] growing at an increasing rate").

213. Houman B. Shadab, The Law and Economics of Hedge Funds: Financial Innovation and Investor Protection, 6 BERKELEY BUS. L.J. 240, 250 (2009).

214. Stephen L. Bonasso, Enemy at the Gates: How Can Investors Stop Hedge-Fund Managers from Unnecessarily Suspending Redemptions?, 7 OHIO ST. ENTREPRENEURIAL BUS. L.J. 139, 145 (2012). 
Second, hedge funds are less regulated as to the kinds of investments they can make, avoiding the regulatory requirements for diversification imposed on mutual funds, for example. ${ }^{215}$ On average, activist hedge funds take a larger ownership stake in a target company than other institutional investors--initially around 6.3 percent, rising to a maximum of 9.1 percent of the target's shares. ${ }^{216}$ Furthermore, hedge funds trade on margin and engage in derivatives trading, strategies that can magnify returns on investment, but that are not available to other institutions, such as mutual and pension funds. ${ }^{217}$

Finally, hedge fund managers suffer fewer conflicts of interest with companies in their portfolios than fund managers at other institutional investors. ${ }^{218}$ For example, in contrast to mutual funds, hedge funds do not sell products to the target firms whose shares they hold. Unlike government pension funds, hedge funds are not subject to extensive political control. As a result, hedge funds are in a good position to monitor corporate boards.

In their monitoring capacity, activist hedge funds push management to take corporate action to produce high returns. These changes can take the form of a sale of the company, a financial restructuring, a change to the company's operating model or governance structure, and other changes. ${ }^{219}$ In other cases, they oppose management-initiated changes, such as proposed mergers that could hurt share value.

While the financial crisis and subsequent weak stock market performance put a temporary damper on activism, the economic recovery since 2009 "has given companies time to pay down debt and build cash

215. See Partnoy \& Thomas, supra note 202, at 112 ("For example, many institutional investors are subject to the prudent investor standard, a rule that mandates diversification of the institution's investments so that no one position puts at risk their returns to their beneficiaries."). Hedge funds are also not subject to heightened fiduciary standards in making their investments, unlike many institutional investors, such as pension funds and mutual funds. Id. at 117-19.

216. Brav et al., supra note 12, at 1747 tbl.II (Panel A).

217. Partnoy \& Thomas, supra note 202, at 119-20.

218. Brav et al., supra note 12 , at 1730 ("Hedge fund managers... suffer fewer conflicts of interest because they are not beholden to the management of the firms whose shares they hold.").

219. Brav et al., supra note 12 , at $1742-43$ tbl.1. More recently, Martin Lipton has stated that there are six "attack devices" employed by hedge funds:

(a) proposing a proxy resolution for creation of a special committee of independent directors

to undertake a strategic review for the purpose of "maximizing shareholder value";

(b) conducting a proxy fight to get board representation ...; (c) orchestrating a withhold the

vote campaign; (d) convincing institutional investors to support the activist's program;

(e) stock loans, options, derivatives and other devices to increase voting power beyond the activist's economic equity investment; and (f) using sophisticated public relations campaigns to advance the activist's arguments.

Lipton, Cain \& Niles, supra note 212. 
piles that activists would like to see returned" to shareholders. ${ }^{220}$ This has led to a resurgence in activism, so that by 2013 over $\$ 100$ billion was dedicated to activist strategies. ${ }^{221}$

\section{The Benefits and Costs of Hedge Fund Activism}

The largest corporate governance benefit of hedge fund activism is reducing the agency costs of corporate management in dispersed publiclyheld corporations. This form of monitoring is reflected in hedge funds targeting firms that are undervalued by the market, often because of poor management. ${ }^{222}$ Empirical studies have found the filing of an activist hedge fund's Schedule 13D creates positive average abnormal returns of 7-8 percent. ${ }^{223}$ These benefits appear to last: firms targeted by activists see a 1.22 percent increase in operating efficiency one year after acquisition. ${ }^{224}$ Activist hedge funds pursue different strategies at targeted firms. ${ }^{225}$ Hedge funds often seek to get a company to use "excess" cash to pay out dividends or buy back shares. For example, after blocking Deutsche Börse's acquisition of the London Stock Exchange, a group of hedge fund activists was able to force Deutsche Börse to commence a share buyback

220. Dan McCrum \& David Gelles, Stirrers and Shakers, FIN. TIMEs (Aug. 21, 2012, 9:16 PM), http://www.ft.com/intl/cms/s/0/db815c6a-e603-11e1-a430-00144feab49a.html\#axzz2vh8sYBW0.

221. Alexandra Stevenson, No Barbarians at the Gate; Instead, a Force for Change, N.Y. TIMES (Jan. 6, 2014, 6:42 PM), http://dealbook.nytimes.com/2014/01/06/no-barbarians-at-the-gate-instead-aforce-for-change/. We note that the universe of hedge funds, of which activists are a small part, is much larger. One source estimated their total capital in 2006 at $\$ 1.2$ trillion. David A. Katz \& Laura A. McIntosh, Corporate Governance: Advice on Coping with Hedge Fund Activism, N.Y.L.J., May 25, 2006 , at 5 , col.1.

222. See Brav et al., supra note 12, at 1730 ("Hedge fund activists tend to target companies that are typically 'value' firms, with low market value relative to book value, although they are profitable with sound operating cash flows and return on assets."). One recent working paper finds that sustained selling of a company's stock by institutional investors significantly raises the odds that it will be targeted by activist hedge funds. Nickolay Gantchev \& Chotibhak Jotikasthira, Hedge Fund Activists: Do They Take Cues from Institutional Exit? 21 (Feb. 2013), available at http://events.isb.edu/FinanceConference2013/UpLoad/323f_hf\%20draft\%202013.2.pdf (unpublished manuscript).

223. Brav et al., supra note 12, at 1730. In contrast, Robin Greenwood and Michael Schor find that while activist hedge funds do produce these abnormal returns, the returns are produced by takeover premiums, not improvements in management. Robin Greenwood \& Michael Schor, Investor Activism and Takeovers, 92 J. FIN. ECON. 362, 363, 374 (2009). The authors find that activist targets which do not result in a takeover have abnormal returns statistically indistinguishable from zero.

224. Christopher P. Clifford, Value Creation or Destruction? Hedge Funds as Shareholder Activists, 14 J. CORP. FIN. 323, 324 (2008). See also Brav et al., supra note 12, at 1772 ("In 2 years, the leverage ratio (by book values) increases on average by 1.3-1.4 percentage points compared to the level during the year before the [hedge fund intervention] ....").

225. Brav et al., supra note 12, at 1733 (detailing "successful forms of shareholder activism during the 1980s"). See also McCrum \& Gelles, supra note 220 (discussing different strategies employed by activist investors to financially benefit corporations in which they have holdings). 
and thereby distribute some of its cash holdings. ${ }^{226}$ Hedge fund manager David Einhorn's run at Apple, seeking to force it to pay out some of its $\$ 140$ billion in cash to shareholders, is another example. ${ }^{227}$ Alternatively, hedge funds may pressure target firms to spin off less efficient divisions or assets, or even force the sale of an entire company. 228

A frequent mechanism for a hedge fund to implement any of these goals is to seek to replace some of the incumbent directors (but less than a majority) through a short slate proxy contest. ${ }^{229}$ For example, TPG-Axon Capital Management ("TPG-Axon") sought the removal of SandRidge Energy's CEO and launched a proxy contest to gain seats on the company's board. ${ }^{230}$ After a hard-fought battle, the company capitulated and agreed to give four board seats to TPG-Axon as well as to formally consider firing the CEO. ${ }^{231}$

When hedge funds own shares in a company that is the target of an acquisition, they want to negotiate a higher price for the target company's shares than the company's management may have negotiated. For example, Carl Icahn and Southeastern Asset Management sought to block the sale of Dell, Inc. to its founder Michael Dell and private equity firm Silver Lake Partners. ${ }^{232}$ In another case involving Novartis's acquisition of Chiron, ValueAct Capital was able to step in and force up the offer premium from 23 to 32 percent. ${ }^{233}$ In such a setting, activist hedge funds can also work to monitor opportunism by other hedge funds in addition to monitoring corporations. Thus, when the hedge fund controlling Sears attempted to freeze out the minority shareholders of Sears Canada, a second activist hedge fund was able to step in and block the underpriced takeover. ${ }^{234}$

226. Kahan \& Rock, supra note 191, at 1035-36.

227. Steven Davidoff Solomon, Unusual Moves in Confronting Apple's Huge Pile of Cash, N.Y. TIMES (Feb. 12, 2013, 4:55 PM), http://dealbook.nytimes.com/2013/02/12/unusual-moves-inconfronting-apples-mountain-of-cash/.

228. Brav et al., supra note 12, at 1741.

229. See Nickolay Gantchev, The Costs of Shareholder Activism: Evidence from a Sequential Decision Model, 107 J. FIN. ECON. 610, 612-13 (2013) (highlighting two instances in which activist shareholders notified current boards of companies that they would be nominating their own slate of directors to pursue an agenda).

230. Michael J. de la Merced, SandRidge Settles Fight with Hedge Fund, N.Y. TIMES (Mar. 13, 2013, 5:11 PM), http://dealbook.nytimes.com/2013/03/13/sandridge-settles-fight-with-activist-investor/.

231. Id.

232. Steven Davidoff Solomon, In Battle Over Dell's Fate, Don't Underestimate Carl Icahn, N.Y. TIMES (July 11, 2013, 3:44 PM), http://dealbook.nytimes.com/2013/07/11/in-battle-over-dells-fatedont-underestimate-carl-icahn/.

233. Kahan \& Rock, supra note 191, at 1037.

234. Id. at 1038 . 
However, hedge funds have detractors. Some corporate lawyers have claimed that hedge funds are "villains," 235 pointing to activist hedge funds" focus on booking short-term profits at the expense of the long-term value of their portfolio companies. ${ }^{236}$ Whether hedge funds harmfully focus on short-term gains is difficult to determine conclusively. ${ }^{237}$ Some evidence would seem to suggest that hedge fund short-termism is not a huge problem. ${ }^{238}$ First, hedge funds seem to have little trouble recruiting longterm investors to support their activist goals. ${ }^{239}$ If a hedge fund's plans actually only produced a short-term gain at the expense of long-term profitability, long-term investors would be reluctant to support them. ${ }^{240}$ Second, as already mentioned, empirical evidence suggests that hedge fund activism improves a firm's long-term prospects. ${ }^{241}$ Third, activist hedge fund holding periods are not that short, with one study finding an average holding period of thirty-one months. ${ }^{242}$ Finally, one study of hedge fund interventions from 1994 to 2007 found that the stock price gains resulting from the initial announcement of a hedge fund's activism were sustained over a five-year period, as were improvements in other measures of returns. ${ }^{243}$ All of this evidence supports the claim that hedge fund activism

235. Katz \& McIntosh, supra note 221 (arguing that activist hedge funds are the villains of the 2000s).

236. Lipton, Deconstructing American Business II, supra note 15, at 1 (arguing that the most important problem for American business in the future is "[p]ressure on boards from activist investors to manage for short-term share price performance rather than long-term value creation."); Roe, supra note 15 , at 982 (reporting that managerial and boardroom autonomy has been justified recently by claims that activist hedge fund shareholders are focused on short-term gains). But see Bebchuk, supra note 15 , at 1638 (arguing against claims that activist investors take profitable short-term actions that are in the long term value-decreasing); Steven Davidoff Solomon, A Label for Activist Investors that No Longer Fits, N.Y. TIMES (July 9, 2013, 3:42 PM), http://dealbook.nytimes.com/2013/07/09/a-label-foractivist-investors-that-no-longer-fits/ (rejecting the claim that hedge funds are short-term shareholders).

237. Thomas W. Briggs, Corporate Governance and the New Hedge Fund Activism: An Empirical Analysis, 32 J. CORP. L. 681, 702 (2007) ("The allegedly value-destroying short term approach of many hedge fund[] activists is harder to analyze, but again seems to cause little concern for other investors.").

238. See generally Roe, supra note 15 , for an extensive discussion of the evidence regarding positive and negative claims that investors have a short-term perspective harmful to corporations, in which the author ultimately rejects these arguments.

239. Kahan \& Rock, supra note 191, at 1089 ("To the extent that the largest shareholders are effectively indexers, a strategy that results in a short-term increase in share price (which benefits hedge funds), but a long-term loss (that hurts long-term shareholders), will not be attractive."). See also Briggs, supra note 237 , at $701-03$.

240. Kahan \& Rock, supra note 191, at 1088-89.

241. Brav et al., supra note 12, at 1731.

242. William W. Bratton, Hedge Funds and Governance Targets: Long-Term Results 10 (Univ. Pa. Law Sch. Research Paper No. 10-17, Sept. 2010), available at http://papers.ssm.com/ sol3/papers.cfm?abstract_id=1677517. See also Brav et al., supra note 12, at 1731-32 ("Hedge funds are not short-term in focus, as some critics have claimed.").

243. Lucian A. Bebchuk, Alon Brav \& Wei Jiang, The Long Term Effects of Hedge Fund 
is not generally a short-term strategy and generates valuable monitoring of corporate management. ${ }^{244}$

Is the value created cost-justified? As we noted above, investors pay hedge fund managers very well. ${ }^{245}$ Investors' interests in the hedge fund are also illiquid. Lockup provisions at hedge funds generally prohibit investments from being withdrawn for a specific period of time after being invested in the fund, often six to twenty-four months. ${ }^{246}$ In addition to the lockup period, funds also require a thirty- to ninety-day notice period before withdrawing funds. ${ }^{247}$ Activist funds normally have longer lockup and notice periods. ${ }^{248}$ Hedge fund managers may also impose additional "gates" or "side pockets" to limit investor withdrawals in crisis situations. ${ }^{249}$ Investors would need to get very high returns to convince them to invest in these limited-liquidity, high-cost investments. ${ }^{250}$ Even so, hedge funds' high costs reduce their net monitoring benefits.

Activism, 114 ColuM. L. REV. (forthcoming Dec. 2014) (manuscript at 13). See also Nicole M. Boyson \& Robert M. Mooradian, Experienced Hedge Fund Activists (Apr. 3, 2012) (unpublished manuscript at 2-3) (on file with authors) (finding that hedge fund activism "can lead to superior long-term target firm and hedge fund performance").

244. Davidoff Solomon, supra note 236. See also, Dionysia Katelouzou, Myths and Realities of Hedge Fund Activism: Some Empirical Evidence, 7 VA. L. \& BuS. REV. 459, 477-83 (2013) (claiming to debunk the myth that hedge funds are short-term in their focus).

245. Some investors prefer to hold a portfolio of hedge funds rather than investing in a single hedge fund. They can do so by buying shares in a "Fund of Hedge Funds", an investment vehicle whose portfolio consists of equity interests in a number of hedge funds. Hedge Fund Strategy-Fund of Hedge Funds, BARClAyHEDGE: ALTERNATIVE INVESTMENT DATABASES, available at http:/www.barclayhedge.com/research/educational-articles/hedge-fund-strategy-definition/hedge-fundstrategy-fund-of-funds.html. These Fund of Hedge Fund investments typically have higher fees than single hedge funds because they include an additional management fee charged by the firm organizing them. $I d$. They do have the advantages of providing a new investor with the services of an experienced fund manager, giving investors some degree of diversification in their investment, and having lower minimum investment requirements. $I d$.

246. Shadab, supra note 213 , at 252 ; Bonasso, supra note 214 , at 149 . In some funds, investors are able to choose longer lockup periods for lower fees. Bonasso, supra note 214, at 149.

247. Id. at 150.

248. Clifford, supra note 224, at 333.

249. Adam L. Aiken, Christopher P. Clifford \& Jesse A. Ellis, Hedge Funds and Discretionary Liquidity Restrictions, J. FIN. ECON. (forthcoming) (manuscript at 2-4) (finding that hedge funds enacted discretionary liquidity restrictions following poor performance and when their assets were more illiquid). A "side pocket" is a separate account created by a hedge fund for segregating illiquid or hardto-value securities. Id. at 6 . A "gate" temporarily, partially, or fully restricts the ability of investors to redeem their interest in the fund. $I d$. at 5 .

250. Recent returns to activism have been high. Dan McCrum \& David Gelles, Activist Investors Celebrate a Banner Year, FIN. TIMES (Dec. 23, 2012, 6:24 PM), http://www.ft.com/intl/cms/s/0/ 6448e810-3a5f-1 le2-a32f-00144feabdc0.html\#axzz3BU00xpIL (stating that "cash has flooded into the sector" because of the high returns to activist funds). See also Boyson \& Mooradian, supra note 243, at 2-4 (finding that experienced activist funds outperformed less experienced funds and that their targets earned higher long-term stock returns than the targets of the less experienced funds). 


\section{Hedge Activists Gain Support from Wolf Packs}

Hedge funds need other shareholders to support their efforts if they are going to be successful in bringing about changes at portfolio firms. One place they may look is other activist hedge funds that take positions in the same companies, sometimes called the "wolf pack."251 While explicit coordination between hedge funds is limited because funds normally want to avoid forming a Schedule 13D group and making the subsequent disclosure, ${ }^{252}$ market forces encourage pack behavior. When one activist fund announces a large stake in a target company, other funds may follow hoping to free ride on the benefits-and these free riders usually support the activist fund. ${ }^{253}$ By joining together, this collection of hedge funds can exert significantly more influence than any individual fund could. ${ }^{254}$ This pack behavior allows hedge funds to establish sufficiently large dollar amounts of holdings to take on even large companies without compromising the diversity of their activism. ${ }^{255}$

Wolf pack behavior appears to be a significant phenomenon. For example, in the proposed 2006 Lexar Media-Micron Technology deal, a wolf pack joined with hedge fund investor Icahn Associates Corp. to oppose the merger, assembling 46 percent of the outstanding shares. ${ }^{256}$ In 2004, the hedge fund Children's Investment Fund announced its opposition to Deutsche Börse's attempt to acquire the London Stock Exchange, leading within weeks to a wolf pack's formation with 35 percent of the outstanding stock. ${ }^{257}$

While wolf packs can force targeted firms to capitulate to the hedge funds' demands, the result will not always be value-enhancing. When Steel Partners, one of the most prominent activist funds, announced its campaign to elect a minority of BKF Capital Group's board, "a concerted 'wolf pack' campaign" of activists formed, allowing Steel Partners to subsequently

251. Andrew R. Brownstein \& Trevor S. Norwitz, Shareholder Activism in the M\&A Context, WACHTELL, LIPTON, ROSEN \& KATZ (May 15, 2006), available at http://online.wsj.com/public/ resources/documents/wlrkmemo51506.pdf ("Many hedge funds move in loosely aligned packs, testing the limits of securities reporting and antitrust rules by taking advantage of the ambiguity in concepts like 'groups' ....").

252. Briggs, supra note 237 , at $697-98,698 \mathrm{n} .109$.

253. Bratton, supra note 149 , at 1379.

254. Id.

255. Id.

256. Jeff Chappell, Hedge Fund Investors Question Lexar-Micron Deal, EDN NETwORK (Apr. 7, 2006), http://www.edn.com/electronics-news/4319016/Hedge-Fund-Investors-Question-Lexar-MicronDeal.

257. Kahan \& Rock, supra note 191, at 1035-36. The wolf pack's stake subsequently grew to between $40-60$ percent of shares. Id. at 1036 . 
succeed in its efforts to elect some directors. ${ }^{258}$ Nevertheless, the firm's employees responded by leaving the company and taking their clients with them, leaving Steel Partners and its wolf pack to take heavy losses on their investments. ${ }^{259}$

From the perspective of our theory, the importance of wolf packs is that they represent large blocks of voting support for the lead hedge fund, with most (if not all) of the pack members having similar voting preferences to the lead fund. In situations where the issue being voted on is one in which all shareholders hold similar interests, such as the desire to get the best price in a sale of the company, having a large wolf pack block will further the interests of all shareholders. However, if the issue is one in which shareholders may disagree, perhaps because of different internal rates of return or views of the appropriate time horizon, then the presence of the wolf pack may result in pushing the outcome of the vote in the direction that the hedge funds prefer, potentially disappointing other investors who have different internal rates of return or time preferences.

The wolf pack scenario shows that there may be some tension between the two positive functions of a shareholder vote. On one side, if we believe that wolf packs provide some private information about the wisdom of a certain corporate decision, the shareholder vote will act to aggregate the private information so that the corporation will make the best decision. On the other hand, if there is a conflict in the preferences among shareholders, then the wolf pack will act to dilute the influence of the other shareholders, and the preference aggregation function of the vote will be less effective. Which of these effects dominates will depend on how influential hedge funds' views are to institutional investors.

\section{Institutional Investors Follow Hedge Funds' Lead}

Even with the support of wolf packs, activist hedge funds need institutional investors to vote with them in order to succeed. ${ }^{260}$ Hedge funds can improve institutional investor monitoring by identifying

258. Timothy A. Kruse \& Kazunori Suzuki, Steel Partners' Activism Efforts at United Industrial, Ronson, and BKF Capital: The Good, The Bad, and The Ugly, 38 MANAGERIAL FIN. 587, 589 (2012) available at http://papers.ssm.com/sol3/papers.cfm?abstract_id=1485696.

259. Id.

260. Gilson \& Gordon, supra note 13, at 897 ("By giving institutions [the ability to vote by creating a proxy fight], the activists increase the value of governance rights; the institutions' exercise of governance rights then becomes the mechanism for creating value for beneficial owners."). See also J.W. Verret, Economics Makes Strange Bedfellows: Pensions, Trusts, and Hedge Funds in an Era of Financial Re-Intermediation, 10 U. PA. J. BUS. \& EMP. L. 63, 69-70 (2007) (discussing how institutional investors may invest in activist hedge funds and facilitate activism). 
underperforming companies, making the necessary undiversified investment in those companies, and taking the leadership role in challenging incumbent management. Hedge fund activism has the ability to mitigate institutional investors' passivity. For example, hedge funds' concentrated holdings allow them to invest the necessary resources even when institutions' holdings are too small to justify activism.

Hedge funds seek support from institutional investors to achieve their goals. ${ }^{261}$ In some cases, this means a two-step approach: hedge funds first talk with institutional investors about the target company, then contact that company once they know they have the support of institutions and their large shareholdings. ${ }^{262}$ Alternatively, some institutional investors "maintain open and regular lines of communication with activists, including sharing potential 'hit lists' of possible targets." 263 Overall though, the hedge funds frequently get institutional support. As one institutional investor manager put it, "[t]he hedge funds have done a marvelous job. No matter how we feel about companies, traditional managers simply cannot move as fast to achieve our aims. We were right behind (the hedge funds), but we couldn't have done it without them." 264

Mutual funds frequently work with hedge funds in shareholder activism. While mutual funds face disincentives to shoulder the cost of monitoring, they are well-situated to support hedge fund activism. ${ }^{265}$ For example, in the Deutsche Börse-London Stock Exchange proposed merger, mutual funds joined with the activist hedge fund to confront the Deutsche Börse board. ${ }^{266}$ In another situation, the Legg Mason mutual fund worked with ValueAct Capital hedge fund to raise the acquiring price for Novartis's acquisition of Chiron in $2005 .^{267}$

Public pension funds and company pension funds are more hesitant to openly follow activist investors than mutual funds. ${ }^{268}$ Public pension fund

261. Lipton, supra note 212 , at 1 (noting that hedge funds seek to "convinc[e] institutional investors to support the activist's program"). Lipton argues that potential target companies should "[m]aintain regular, close contact with major institutional investors [as] CEO and CFO participation is very important." Id.

262. McCrum \& Gelles, supra note 220 ("The activists are having discussions with major shareholders beforehand. . . They can go in and say, 'Most of your shareholders feel this way."').

263. Lipton, Cain \& Niles, supra note 212 (claiming that even when institutions don't have limited partnership interests in these funds, they are actively supporting them).

264. Louise Armistead, Saved by the Growing Power of Hedge Funds, SUNDAY TIMES, (Mar. 13, 2005) , http://www thesundaytimes.co.uk/sto/business/article103547.ece.

265. Kahan \& Rock, supra note 191, at 1048.

266. Id. at 1035 .

267. Id. at 1037 .

268. Id. at $1061-62$. 
trustees are normally elected or appointed officials who lack both the compensation incentives and often the credibility and knowledge to pursue aggressive investment strategies. ${ }^{269}$ In addition, public pension funds operate in a political environment where aggressive activism might be seen as inappropriate, ${ }^{270}$ while the company pension fund manager prefers to be one step removed and not as directly associated with the activism. ${ }^{271}$ But, overall, hedge funds actively and often successfully court the voting support of institutional investors.

\section{Institutional Investors Invest Heavily in Hedge Funds}

Institutional investors support hedge funds in a more direct way as well-they are their main source of investment capital. ${ }^{272}$ Citi Prime Finance, a division of Citibank, estimates that institutional investors accounted for 66 percent of all hedge fund capital, with over $\$ 1.47$ trillion dollars in hedge fund investments in $2011 .{ }^{273}$ It projects these investment levels to rise rapidly over the next several years to reach $\$ 2.47$ trillion by $2016 .{ }^{274}$ Hedge funds would be hard pressed to engage in many of their activities without this capital.

More importantly for our purposes, this suggests that institutional investors have a second interest in supporting hedge fund activism beyond the returns that they generate in any particular company by voting in favor of activists' agendas-a direct return on their investments in the hedge funds themselves. In other words, institutional fund investors have multiple interests in hedge fund activism generating increases in target company value.

When a private pension fund invests in an activist hedge fund, it is supporting the hedge fund's activism. ${ }^{275}$ This investment solves two problems that company pension funds would face if they were activists

269. Id. at 1059-61.

270. See id. at 1059-60 (discussing pension fund controllers who have come under scrutiny for potentially politically-motivated governance choices).

271. Verret, supra note 260 , at 70 ("With corporate governance activity one step removed, corporate pension managers can wash their hands of the dirty work.").

272. See Lipton, Cain \& Niles, supra note 212 ("'Activist Hedge Fund' has become an asset class in which institutional investors are making substantial investments.").

273. CITI PRIME FINANCE REPORT, supra note 132, at 33 tbl.21, 34

274. Id.

275. However, some commentators question whether these funds are a major source of hedge fund capital. See Kahan \& Rock, supra note 191, at 1068 ("While we lack precise data, we do not believe that corporate pension funds are a major source of capital for hedge funds at this time. And, given the declining importance of corporate defined benefit plans, we are skeptical that they ever will become one."). 
themselves. First, being an investor rather than a direct participant allows the pension fund manager to be far removed from any potential fallout related to the activism. ${ }^{276}$ Additionally, a pension fund manager can take small stakes in multiple activist hedge funds, which will in turn acquire the large stakes in a target necessary for efficient activism. This permits the private pension fund to make what are essentially undiversified, potentially more valuable, investments than it would otherwise be allowed to make. ${ }^{277}$

Other types of institutional investors also put large sums of money into hedge funds. ${ }^{278}$ These include university endowments, sovereign wealth funds, insurance companies, and foundations. ${ }^{279}$ Sovereign wealth funds' investment in hedge funds is increasing at a particularly rapid rate. In each case, these investment vehicles will have strong incentives to support hedge funds generally, and more particularly when they engage in hedge fund activism.

Institutions that hold both an interest in an activist hedge fund targeting a firm as well as stock in the target firm may pose a problem for our theory of shareholder voting. Suppose the hedge fund proposes that the target firm take actions that maximize the value of the hedge fund's interest in the firm, but which are value-decreasing for the firm overall. ${ }^{280}$ If the institution decides to vote its stock to support the hedge fund's activism, and thereby maximize the value of its investment in the fund, it will be voting not to maximize the value of the target firm. ${ }^{281}$ As discussed in Part III.A.2, there is substantial evidence that hedge funds are not shortterm investors, but if this were to occur, it would violate our claim that shareholders vote to maximize firm value.

To summarize, institutions that own interests in activist hedge funds will have two different interests in their activism: (1) their direct interest in maximizing the value of their portfolio companies, and (2) their indirect interest in maximizing the value of their investment in the hedge fund. The claim that institutional investors often follow hedge funds in their voting activism, ${ }^{282}$ while accurate as far as it goes, misses this second very

276. Verret, supra note 260 , at 70 .

277. Id.

278. CITI PRIME FINANCE REPORT, supra note 132, at 10, 29-30.

279. Id.

280. This could happen if there is a divergence in the long-term and short-term value of the firm because of hedge fund proposals.

281. See Gregor Matvos \& Michael Ostrovsky, Cross-Ownership, Returns, and Voting in Mergers, 89 J. FIN. ECON. 391, 397 (2008) (finding that mutual funds that hold shares in both a target and acquirer which have entered into a proposed merger are more likely to vote for the merger).

282. Gilson \& Gordon, supra note 13 , at 867 . 
important motivation behind institutional investors' support for hedge fund activism.

\section{Proxy Advisory Services' Role in Hedge Fund Activism}

One final set of important players in hedge funds' voting activism is the proxy advisory firms. If ISS recommends that its institutional clients vote in favor of the hedge fund's candidates in a contested election, the hedge fund is much more likely to win. ${ }^{283}$ Effectively, the hedge fund supplements its direct connections with institutional investors by leveraging ISS's voting advice and information processing to reach out to institutional shareholders. It is extremely effective: one study examined thirteen incidents where ISS backed hedge funds in proxy fights for board seats and found that in twelve of them the hedge fund won. ${ }^{284}$ In other words, when ISS backs hedge funds, "they win."285

Not surprisingly, hedge funds try hard to persuade ISS of the merits of their plans for the targeted firms. ${ }^{286}$ Hedge funds often prepare presentations and legal briefs about their plans and even hire investment bankers to prepare white papers to promote the activism. ${ }^{287}$ Of course, companies are also aware of the importance of the ISS voting recommendation and prepare their own counterarguments and presentations. $^{288}$

Some see proxy advisory firms as favoring activists over managers. ${ }^{289}$ For example, in 2003 Barington Capital Group proposed the election of two new directors to the board of Nautica Enterprises. ${ }^{290}$ Barington was able to convince ISS to give positive recommendations for its nominees,

283. Cindy R. Alexander et al., The Role of Advisory Services in Proxy Voting 34-35 (Nat'l Bureau of Econ. Research, Working Paper No. 15143, 2009), available at http://papers.ssm.com/ sol3/papers.cfm?abstract_id=1434658 (finding that proxy advisory firms' recommendations are a good predictor of proxy contest outcomes, with positive recommendations in favor of one party leading to increased voting support).

284. Briggs, supra note 237, at 698.

285. Id.

286. See id. at 699 ("The object nevertheless remains to persuade, and it appears that hedge fund activists are taking advantage of their opportunities in new ways. ISS has come to be treated almost as a sort of latter-day cross between Solomon and the Pied Piper of Hamelin before which contestants make road-show financial presentations and, in at least one instance, purely legal arguments.").

287. Id.

288. See Lipton, Cain \& Niles, supra note 212 (arguing that a target firm must make a "sophisticated presentation of the company's finances and business to have any prospect that [proxy advisory firms] will reject the activist's argument and support the company's").

289. Id. (stating that "ISS and Glass Lewis ... favor activists over management").

290. Kahan \& Rock, supra note 191, at 1030. 
and one month later both nominees were elected. ${ }^{291}$ Additionally, ISS may provide a convenient third-party opinion on the value of a hedge fund's strategies. For example, in the conflicted MONY deal where two hedge funds put forth competing plans, ${ }^{292}$ ISS backed the fund it believed best represented shareholders, Highfields, and ultimately Highfields's proposal was successful. ${ }^{293}$ In short, proxy advisory firms play an important role in securing institutional voting support for hedge fund activism.

\section{Hedge Funds and Our Theory of Corporate Voting}

Tying the discussion in Part III.A back into our theory, hedge funds are shareholders whose return is contingent on the stock price and who have strong incentives to raise that stock price for all shareholders. Because of their independence and sharp focus on the stock price, hedge funds are well-positioned to monitor board conflict situations using the shareholder vote. Hedge funds also stimulate other shareholders to overcome their rational reticence to engage in activist, informed voting behavior.

In addition, with their financial expertise and willingness to pay for investment bankers' services, hedge funds are able to bring private information to a corporate decision, such as the appropriate price to be paid in a merger. This permits shareholder voting to play the positive role of aggregating private information to help reach a superior corporate decision.

Finally, hedge fund driven voting may further serve a preference aggregation function. Hedge funds may have higher internal rates of return and view a short-term return (if we accept corporate management's perspective) more positively than long-time horizon shareholders. By aggregating the votes of hedge funds and institutional investors, we ensure that the outcome of the vote is likely to reflect the underlying preferences of all of the company's significant shareholders. Proxy advisory firms further facilitate this process by assisting institutional investors to solve the collective action problem and fully express their preferences in a vote.

Going back to the example discussed in Part I.C.2.b, the fight between Biglari Holdings and Cracker Barrel over a shareholder resolution that the corporation should take on significant debt in order to make an immediate twenty-dollar per share dividend, Biglari's preferences were for a shortterm payout, whereas management preferred to continue to use the cash in its existing business strategy. While management could have ignored any

291. Id.

292. Id. at 1073 .

293. Id. at 1073-74. See also Gantchev, supra note 229, at 612-13. 
vote on Biglari's initial shareholder proposal, it instead chose to put the proposal on the ballot itself to see what Cracker Barrel's shareholders thought about the matter. ${ }^{294}$ This permitted the board to find out what shareholders' aggregate preferences were-and to learn that its investors supported management's position. This is a good illustration of how a shareholder vote can provide valuable information to a board.

To summarize, hedge funds have been at the core of high-dollar immediate-value shareholder activism. While they play the leading role in this activism though, other players are important, including institutional investors and proxy advisory firms.

\section{B. LOW-DOLLAR IMMEDIATE-VALUE VOTING SituATIONS}

Low-value shareholder voting situations arise when shareholders are asked to vote on issues that have little if any immediate discernible effect on the company's stock price. Given that voting is costly, one might conclude that these are not suitable occasions for exercising the franchise. However, our theory of shareholder voting can be extended to situations in which the value of intervention has a long-term impact on firm value that does not show up immediately in stock price.

As a theoretical basis for this distinction between short- and long-run value, we provisionally accept corporate management's stated view that these can be different things. ${ }^{295}$ For instance, boards frequently claim such a difference exists when they use defensive tactics to block a tender offer, arguing that they have a better strategy for managing the corporation to maximize its long-term value. ${ }^{296}$ Commentators, regulators, and investors have accepted this idea that long-term value is the right metric for managing the corporation. ${ }^{297}$

294. Cracker Barrel and Biglari Proxy Contest Chronology, supra note 95.

295. See Paramount Commc'ns, Inc. v. Time, Inc., 571 A.2d 1140, 1154 (Del. 1989) ("Directors are not obliged to abandon a deliberately conceived corporate plan for a short-term profit unless there is clearly no basis to sustain the corporate strategy."); Lipton, Deconstructing American Business II, supra note 15, at 1 (stating that the most important problem for American business in the future is "[p]ressure on boards from activist investors to manage for short-term share price performance rather than longterm value creation."); Roe, supra note 15, at 979-80 ("It would not be unfair . . to pose the policy issue as: Whether the long-term interests of the nation's corporate system and economy should be jeopardized in order to benefit speculators interested ... only in a quick profit ... ?" (quoting Martin Lipton, Takeover bids in the Target's Boardroom, 35 BuS. LAW 101, 104 (1979)).

296. See, for instance, the argument of Time, Inc.'s management's in Paramount, 571 A.2d at 1149-50 ("The Time board maintained that the Wamer transaction offered a greater long-term value for the stockholders and, unlike Paramount's offer, did not pose a threat to Time's survival and its 'culture."').

297. Bebchuk, supra note 15 , at 1639-40. 
Assuming arguendo that this is a potential metric for evaluating corporate activities, then corporate voting can be justified whenever (1) managers' actions affect the long-term value of the company; and (2) there are systemic benefits that will be realized by all shareholders if they could monitor managers' divergence from this value, and the cost of the monitoring would not consume the benefit. A shareholder vote to remove takeover defenses, such as classified boards, might be one example. ${ }^{298}$ The costs of such a vote are small and the value of removing the classified board is only likely to show up if the company becomes a takeover target. ${ }^{299}$

Shareholders should use the vote to play this monitoring role for actions that pose director conflicts of interest, such as interested transactions, or those involving potentially captured boards setting officer compensation. For example, when the board is considering managerial compensation, concerns about structural bias and independent directors' willingness to bargain hard over pay levels may make shareholders useful additional monitors of CEO pay, ${ }^{300}$ even if resulting changes to pay levels do not affect stock price.

Some initially low-value shareholder votes could also trigger subsequent high-value activism that affects stock price. For instance, a failed Say on Pay vote, in which the company receives a low level of shareholder support for its executives' compensation, could act as a signal of shareholder discontent that attracts the interest of an activist hedge fund. The recent case of Hess Corp. ("Hess") and Elliot Management Corp. ("Elliot Management") may be just such a situation. In 2012, Hess shareholders cast only 58 percent of their votes in favor of management's Say on Pay proposal, ${ }^{301}$ indicating to the market that the company's shareholders were unhappy. In 2013, activist hedge fund Elliot Management launched a proxy contest for control of Hess. This hotly contested fight led to Elliot Management getting several seats on the Hess

298. Thomas \& Cotter, supra note 85 , at 398 (finding that boards are more willing to remove classified boards after precatory shareholder proposals asking them to do so receive strong shareholder support).

299. Cunat et al., The Vote is Cast, supra note 14, at 1945-46 (finding that in close votes, the passage of shareholder proposals to declassify the board increases firm value).

300. See luclan BebchuK \& Jesse Fried, PAy Without PERFormance: The UNfulfilled PROMISE OF EXECUTIVE COMPENSATION 100 (2004) (describing a circumstance in which it would be helpful to have shareholders act as additional monitors of CEO pay).

301. Daniel Gilbert \& Joann S. Lublin, Board Pay Adds Fuel to Hess Battle, WaLl ST. J. (Mar. 25, 2013, 8:03 PM), http://online.wsj.com/news/articles/SB1000142412788732346620457838267229 6842906. 
board. ${ }^{302}$ More generally, any time a company fails its Say on Pay vote, this is likely to signal to activist hedge funds that it is suffering from poor performance, excess compensation levels, and a high degree of shareholder discontent.

We recognize that voting on low dollar value proposals is more difficult to justify than voting that results in high immediate shareholder value. Long-term value is a slippery concept that (some have argued) managers have used to justify entrenching themselves in power, ${ }^{303}$ and which could potentially serve as a justification for any action directors wish to take. As a result, we believe that its use as a criterion for allowing shareholder voting must be considered on a case-by-case basis and be critically evaluated. For example, we find it difficult to justify shareholder voting on Rule $14 \mathrm{a}-8$ corporate social responsibility proposals. While proponents of such measures may claim that they relate to the firm's longterm value, we find these arguments to be quite attenuated and lacking support in empirical research. ${ }^{304}$

In the remainder of this section we provide a more detailed examination of voting in low immediate-value contexts and how that voting too is consistent with our approach to shareholder voting.

\section{Shareholders Have Insufficient Incentives to Lead on These Issues}

In low-dollar immediate-value situations, the costs to an investor to initiate activism may exceed the immediate payoffs, so that few investors are likely to step up to the plate. For starters, activist hedge funds are focused on actions that will immediately increase shareholder value. Lowdollar immediate-value situations are not interesting to hedge funds because: (1) they usually need to return capital to investors within a sixmonth window, and (2) their form of intervention may have high transaction costs (requiring liquidity to buy and hold a long-term stake). As with high-value situations though, the agency costs of intermediary capitalism make it unlikely that institutional investors will initiate action. ${ }^{305}$

302. Michael J. de la Merced, How Elliot and Hess Settled a Bitter Proxy Battle, N.Y. TimES (May 16, 2013, 9:13 AM), http://dealbook.nytimes.com/2013/05/16/hess-and-elliott-settle-fight-overcompanys-board/.

303. Bebchuk, supra note 15 , at 1642-43.

304. Thomas \& Cotter, supra note 85 , at 370 ("Academic research has generally concluded that corporate governance proposals raise important substantive issues, while the social responsibility proposals are frequently viewed as frivolous."). In the context of Rule $14 \mathrm{a}-8$, we would draw the line at shareholder voting that relates to firms' corporate governance structures and put the burden on proponents of moving outside of those boundaries to justify their positions.

305. See supra Part II.A.2. 
Taking a leadership position means incurring the costs of activism, and in low-dollar immediate-value situations, the chance of recouping these costs quickly through activism is very small. On top of that, an individual institution that initiates activism will still face the same free rider problems that it faced in high-dollar immediate-value situations. ${ }^{306}$

\section{Mandatory Voting and Proxy Advisory Firms Help Shareholders to Act Collectively}

Even if one investor initiates activism, other institutional investors will not want to incur the necessary costs to cast informed votes if they do not see an immediate payoff sufficient to cover these costs. ${ }^{307} \mathrm{Here}$, the governmental mandate for fiduciary voting plays a larger role than in the high-impact context previously discussed. For institutional shareholders following business plans that make them rationally reticent to vote, mandatory voting facilitates a solution to the shareholders' collective action problem, especially when the immediate payoffs to voting are small. ${ }^{308} \mathrm{~A}$ second justification could be that when short-term value effects are low, but long-term value is adversely impacted, there might be a lack of shareholder monitoring, so the government mandates informed institutional corporate voting.

306. One exception might be the Shareholder Rights Project that was started by Professor Lucian Bebchuk. It seems to be a type of third-party corporate governance activist, acting on behalf of a number of institutional investors that ultimately are the sponsors for these board declassification proposals. THE SHAREHOLDER RIGHTS PROJECT 2012 REPORT, SHAREHOLDER RIGHTS PROJECT 1-3 (2012), available at http:/srp.law.harvard.edu/releases/SRP-2012-Annual-Report.pdf. Based on the statistics reported in its documents, it appears to have been very successful in getting companies to declassify their boards. Id. at 9 . But it is an open question whether such an organization would be possible without the uncompensated efforts of a number of Harvard Law School students and faculty.

307. See Jill E. Fisch, Relationship Investing: Will it Happen? Will it Work?, 55 OHIO ST. L.J. 1009, 1019-20 (1994) ("When investors decide whether to commit resources, they are more concerned with whether an institution performed better than others than with the return realized by the institution. If relationship investing does not create a competitive advantage, an institution has little incentive to engage in it, even if it creates net present value."); Edward B. Rock, The Logic and (Uncertain) Significance of Institutional Shareholder Activism, 79 GEO. L.J. 445, 452-53 (1991) ("What interferes with the realization of the optimists' hope-the hope that institutional investors will be as active, informed, and skeptical as individuals holding an equivalent stake-are the agency costs. Money managers, like outside directors, but unlike the large individual shareholders who institutional shareholders are thought to resemble, have precious few economic or legal incentives to discipline corporate management actively, while facing substantial disincentives.").

308. In a related vein, if the government is concemed about potential conflicts of interest in institutional voting, it can require disclosure of how the institution votes its shares so that its beneficiaries can assess whether the fund voted to maximize the value of its investment. This may be the justification for the requirement that mutual funds disclose their voting records on corporate matters, thereby potentially exposing any pro-management biases arising out of the funds' efforts to sell their retirement plan services. See supra Part II.B.1. 
To satisfy the government mandate, institutional investors need to be informed and to decide how to vote their shares. Proxy advisory firms provide an efficient source of information, and voting recommendations play a different role in low-impact contexts. In both high- and low-dollar immediate-value situations, proxy advisory firms help to solve the monitoring problem by offering a low-cost way for institutional investors to inform themselves about issues on the corporate ballot and in some cases to cast votes for the institutions. As previously discussed, in the high-value case, activist hedge funds are already providing potential leadership on corporate governance issues by bringing them to shareholders' attention. Rationally reticent institutions will be able to follow the hedge funds' lead in casting their ballots, although proxy advisory firms often function as independent verifiers of the truth of the hedge funds' claims and the target company management's counterclaims.

In low-dollar immediate-value cases, institutions generally vote only because they are required by law to do so, and they want to spend the least amount of money possible to cast their ballots in an informed, valuemaximizing way so as to comply with their legally mandated duties. Proxy advisory firms play a valuable role by reducing voting costs significantly. Exploiting economies of scale, these firms provide necessary information to a wide set of clients at a lower price than they could obtain for themselves; using this information, they may be better able than their clients to determine how to vote the stock in order to increase firm value. ${ }^{309}$ In other words, proxy advisory firms' recommendations may provide needed guidance to institutions on how to cast their votes so as to maximize firm value.

Even in situations where the shareholder vote relates to actions that create no value, or even negative value, for shareholders, proxy advisory firms may minimize institutions' voting costs. In these situations, the institution will have even less incentive to invest its own time and resources in deciding how to vote, making it desirable to completely outsource the information gathering and decisionmaking to a (cheaper) third party. This might be the case for Rule $14 a-8$ social responsibility proposals.

In cases where the stakes for the shareholders are lower, it is important

309. Cotter, Palmiter \& Thomas, supra note 177 , at 6-8. This last point assumes that proxy advisory firms have better information at a lower cost on how to maximize share price than do their clients. It might also be the case that the proxy advisory firms simply know their clients' preferences so well that their voting recommendations reflect them accurately. 
that the signals coming out of the proxy advisory firms be unbiased. If they are not, and the voting adviser recommends value-decreasing action, then their institutional clients are unlikely to conduct sufficient research to detect the difference. While corporate management will frequently point out any imperfections in proxy advisory firms' recommendations, possible regulatory responses remain in play.

\section{The Example of Say on Pay}

One example of low-dollar immediate-value votes are the Say on Pay advisory votes on executive compensation that are required by DoddFrank. $^{310}$ As discussed below, Say on Pay votes may increase both immediate value as well as long-term value for shareholders, net of the costs of voting. Shareholders use Say on Pay votes to target companies that exhibit both poor performance and high levels of executive pay. ${ }^{311}$ However, even considerable overpayments to corporate managers may not affect stock prices when the companies in question have market capitalizations in the billions. In other words, for a $\$ 100$ billion company, the loss of several million dollars in compensation overpayments does not immediately affect stock price. ${ }^{312}$

The Say on Pay vote might also be viewed as a vote on the long-term value of the firm because compensation practices reflect the quality of corporate governance: firms with weak governance structures often suffer from poor performance and high levels of managerial compensation. ${ }^{313}$ Say on Pay may affect governance and compensation at firms for a variety of reasons, which we identify here and discuss in the remainder of this section. First, if a CEO is powerful enough to extract rents from his or her firm, then Say on Pay may provide the board of directors with additional leverage to negotiate a better deal for the firm. ${ }^{314}$ Second, if directors are

310. James F. Cotter, Alan R. Palmiter \& Randall S. Thomas, The First Year of Say-on-Pay Under Dodd-Frank: An Empirical Analysis and Look Forward, 81 GEO. WASH. L. REV. 967, 977-79 (2013)

311. See infra text accompanying note 321 .

312. See Steven Davidoff Solomon, A Vote Goes Against Outsize Executive Pay, but It's Hardly a Blow, N.Y. TIMES (Nov. 5, 2013, 8:33 PM), http://dealbook.nytimes.com/2013/11/05/a-vote-goesagainst-outsize-executive-pay-but-its-hardly-a-blow/ (noting that Oracle's general counsel argued that a $\$ 50$ million overpayment to its CEO would constitute only 0.36 percent of its free cash flow).

313. It might also constitute "a referendum or vote of confidence in the CEO-empowering shareholders by providing a mechanism through which they can punish a CEO for poor performance." Cuñat et al., Say Pays!, supra note 14, at 9.

314. Protecting Shareholders and Enhancing Public Confidence by Improving Corporate Governance: Hearing Before the Subcomm. on Sec., Ins., \& Inv. of the S. Comm. on Banking, Hous. \& Urban Affairs, 111 th Cong. 47-49 (2009) (prepared statement of John C. Coates IV, John F. Cogan Jr., 
worried about being reelected to the board, they may attach great importance to the level of shareholder support in a Say on Pay vote, and therefore be quite willing to reduce compensation levels or eliminate abusive pay practices if shareholders or proxy advisory firms ask them to do so $^{315}$ Finally, Say on Pay may improve communication between shareholders and managers on compensation issues, which could result in a general improvement of corporate governance. ${ }^{316}$

\section{a. Dodd-Frank Makes a Shareholder Say on Pay Vote Mandatory}

In response to the financial crisis that began in 2007, Congress enacted Dodd-Frank, including a provision that required public companies to hold an advisory shareholder vote on the compensation of their top executives. ${ }^{317}$ Shareholders strongly supported existing pay practices at most firms with Say on Pay votes in the 2011 proxy season, the inaugural year for Say on Pay, with these proposals garnering on average 91.2 percent support. ${ }^{318}$ These average support levels continued to be high in subsequent years, with more than three-quarters of companies in the Russell Index receiving at least 90 percent shareholder support in 2012 and $2013 .{ }^{319}$ At the other end of the spectrum, only 1-2 percent of firms (40 to 60 of the firms in the Russell 3000 index of U.S. stocks) received less than 50 percent shareholder support during these same years. ${ }^{320}$

Professor of Law \& Economics, Harvard Law School), available at http:/www.gpo.gov/fdsys/pkg/ CHRG-111 shrg55479/pdf/CHRG-111shrg55479.pdf.

315. Fabrizio Ferri \& David A. Maber, Say on Pay Votes and CEO Compensation: Evidence from the U.K., 17 REV. FIN. 527, 531 (2013).

316. Id.

317. Dodd-Frank Wall Street Reform and Consumer Protection Act, Pub. L. No. 111-203, sec. 951, 124 Stat. 1375, 1899 (2010) (adding new section 14A to the Securities Exchange Act of 1934). See also Thomas, Palmiter \& Cotter, supra note 4, at 1225 (discussing the phase-in of the requirement based on the size of the company).

318. TED ALLEN ET AL., ISS, PRELIMINARY 2011 U.S. POSTSEASON REPORT 2 (updated Aug. 8, 2011), available at http://blog.issgovernance.com/docs/2011USSeasonPreview. Equilar, a leading provider of data on executive pay, surveyed 2,252 companies from the Russell 3000 as of June 30 , 2011, almost 75 percent of which passed their Say on Pay votes with over 90 percent approval.

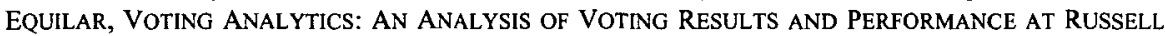
3000 COMPANIES 1 (July 2011), available at http://www.equilar.com/knowledge-network/researcharticles/2011/pdf/Equilar-Voting-Analytics-July2011.pdf. See also Say-on-Pay Support Runs High in 2013, With Few Exceptions, CORP. COUNS. WKLY. (BNA), June 6, 2013 (reporting a study by Meridian Compensation Partners that found on average 90 percent of shareholders voted in favor of company Say on Pay proposals, with only 2 percent of Russell 3000 companies receiving less than 50 percent support); Cotter, Palmiter \& Thomas, supra note 310, at 998-1001 (providing an in-depth discussion of early 2012 say-on-pay voting results).

319. Say-on-Pay Support Runs High in 2013, With Few Exceptions, supra note 318; Cotter, Palmiter \& Thomas, supra note 310 , at 1000.

320. Cotter, Palmiter \& Thomas, supra note 310, at 999-1000; Say-on-Pay Support Runs High in 
What led shareholders to differentiate among companies in their votes? One salient fact is that shareholder votes were highly correlated with company share returns and CEO pay, with low returns and high CEO pay resulting in lower Say on Pay support; excess compensation levels and poor corporate performance were important triggers for negative stockholder votes. ${ }^{321}$ Another important factor that influences shareholder voting is the voting recommendation of proxy advisory firms such as ISS and Glass Lewis. $^{322}$

\section{b. Say On Pay Causes Changes to Compensation Practices}

A key question is whether proxy advisory firms "mostly act as information intermediaries by gathering and processing information for institutional investors who need to fulfill their fiduciary duties to vote, or [whether] they also identify and promote superior governance practices." ${ }^{323}$ One study concludes that ISS and Glass Lewis are primarily information gatherers, but that their recommendations are correlated with voting results. ${ }^{324}$ In particular, it determines that negative recommendations by either ISS or Glass Lewis had a substantial negative impact on Say on Pay vote totals, with an ISS negative recommendation lowering the total by 24.7 percent and a Glass Lewis negative recommendation leading to a 12.9

2013, With Few Exceptions, supra, note 318. See also GEORGESON, REPORT: FACTS BEHIND 2013 FAILED SAY ON PAY VOTES (2013), available at http://www.computershare-na.com/sharedweb/ georgeson/georgeson_report/GeorgesonReport_061113.pdf\#1 ("In 2011, 36 U.S. corporations failed to receive majority shareholder support for their MSOP proposal and in 2012 that number increased to 59. Based on the YTD results for 2013, it seems that there could be fewer MSOP failures this year compared to 2012."); Mary Hughes, Pay-for-Performance Is Still No.I Issue in Say-on-Pay Success, 16 CORP. GOVERNANCE REPORT (BNA) No. 85, Aug. 5, 2013 ("Say-on-pay statistics in 2013 showed that 77 percent of companies in the Russell 3000 index of U.S. stocks received at least 90 percent shareholder support, compared to 76 percent in 2012 . . Only 43 companies, or 2.3 percent of Russell 3000 companies failed say-on-pay."). Some commentators claim that 67 percent support is a more important threshold because "ballots that fail to garner a two-thirds majority are an indication of potential problems, especially since more than 90 percent of the votes analyzed passed with a supermajority." RyAN KRAUSE, KIMBERLy A. Whitler \& MATTHEW SEMADENI, CONFERENCE BD., Director Notes: WhEn Do ShaReHolders CARE ABOUT CEO PAY? 2 (2013).

321. Cotter, Palmiter \& Thomas, supra note 310, at 998-1001. One experimental study found that study participants were "significantly more likely to reject high CEO pay relative to low CEO pay only if company performance was poor." KRAUSE, WHITLER \& SEMANDI, supra note 320, at 3 (emphasis in original). This suggests that poor performance is the trigger for shareholders to engage in closer scrutiny of executive pay levels.

322. E.g., Cotter, Palmiter \& Thomas, supra note 310, at 1001 ("ISS recommendations continue to play a key role in the say-on-pay voting process.").

323. Ertimur, Ferri \& Oesch, supra note 11 , at 952.

324. First, the study detects a small but significantly negative mean abnormal return when ISS issues an unexpected negative voting recommendation in a Say on Pay vote, which is consistent with it performing an information gathering function. Id. at 953 . 
percent drop. The study also finds that 55 percent of the companies receiving negative ISS voting recommendations reported compensation plan changes in response to Say on Pay votes, and that their responsiveness increased with the level of negative shareholder votes. However, the study finds no stock market reaction to compensation changes made after the Say on Pay vote. 325

A second study focusing on the impact of proxy advisory firms' voting recommendations on Say on Pay votes examines changes that companies made to their compensation programs before Say on Pay votes. ${ }^{326}$ It finds that third-party advisers can induce firms to adopt compensation plans that they favor, or to reject certain types of plans that they disfavor (such as tax gross-ups for change of control agreements). However, the study detects a small, statistically significant negative stock market reaction to plan changes "aligned" with ISS and Glass Lewis policies, and no such change with compensation plan changes that are "unrelated" to proxy adviser policies. ${ }^{327}$ In sum, Say on Pay's impact on pay practices at targeted firms may lead to small negative market decreases-at least for the first year of Say on Pay-if firms adjust their compensation practices in line with ISS's recommendations before holding their first vote.

\section{c. Impact of Say on Pay Votes on Firm Value}

Several studies attempt to measure the effect of Say on Pay on firm value. Vincente Cuñat, Mireia Giné, and Maria Guadalupe completed a study on Rule 14a-8 advisory shareholder proposals from 2006-2010 that request that companies permit their shareholders to vote on executive compensation at the firm. ${ }^{328}$ It examines the immediate effect on firm stock market returns as well as longer term effects on CEO compensation, accounting performance, productivity, and firm policies. It finds that on the day of the shareholder vote, for Say on Pay proposals that receive more than 50 percent shareholder approval, the company experiences a positive abnormal return of 2.4 percent relative to ones that fail. ${ }^{329}$ This study reports that where voting crosses the 50 percent threshold, there is a 50

325. Id. at 953-55. The study also finds that 36 percent of companies that receive negative ISS voting recommendations file additional documents with the SEC prior to the vote. Id. at 955 n.4.

326. David F. Larcker, Allan L. McCall \& Gaizka Ormazabal, Outsourcing Shareholder Voting to Proxy Advisory Firms 5 (Rock Ctr. for Corporate Governance, Working Paper No. 119, 2014), available at http://ssm.com/abstract $=2101453$.

327. Id. at 7-8.

328. Cuñat et al., Say Pays!, supra note 14, at 2.

329. Id. at 4 . 
percent higher likelihood of the proposal being implemented by the firm in question, and that firms implementing Say on Pay "have higher growth in earnings per share, return on assets, return on equity and Tobin's $Q$ one year after the vote." 330 However, the study finds only small effects on executive compensation, with a 4 percent reduction in salary increases. ${ }^{331}$ It suggests that Say on Pay "serves to monitor and incentivize CEOs to deliver better firm performance by providing a clear mechanism for shareholders to voice their opinions, as confirmed by major improvements in shareholder value and firm performance among the firms in [the] sample." 332

Another recent study by Peter Iliev and Svetla Vitanova examines the announcement of the SEC rules that gave smaller firms an additional two years before being subjected to the new Say on Pay requirement imposed on larger public companies. ${ }^{333}$ They find that the announcement of this rule led to a positive 1.5 percent three-day return for firms that were exempt from the new Say on Pay vote versus those that were not. ${ }^{334}$ There are similar findings as to the Congressional adoption of the legislation itself, although there is not unanimity on this point. ${ }^{335}$

Similarly, another paper by Ricardo Correa and Ugur Lel analyzing Say on Pay votes in the eleven countries that have enacted this kind of legislation compares compensation levels and firm value in these countries with those in twenty-seven countries that have not done so. ${ }^{336}$ The authors find a positive and statistically significant increase in firm value after the adoption of Say on Pay laws in companies based in the eleven countries that have adopted these laws. ${ }^{337}$

330. Id. at 5 .

331. Id.

332. Id. at $5-6$.

333. Peter Iliev \& Svetla Vitanova, The Effect of the Say-on-Pay Vote in the U.S. 2 (Feb. 27, 2014), available at http://ssm.com/abstract=2235064 (unpublished manuscript).

334. Id at 3 .

335. Jie Cai \& Ralph A. Walking, Shareholders' Say on Pay: Does it Create Value?, 46 J. FIN. \& QUANTITATIVE ANALYSIS 299, 334-35 (2011) (finding positive and statistically significant stock price increase in firm values at companies with high abnormal CEO compensation, or low pay-forperformance sensitivity, within the three days surrounding the House of Representatives' passage of Say on Pay legislation). But see David F. Larcker, Gaizka Ormazabal \& Daniel J. Taylor, The Market Reaction To Corporate Governance Regulation, 101 J. FIN. ECON. 431, 432 (2011) (finding that Say on Pay legislation caused an insignificant market reaction).

336. Ricardo Correa \& Ugur Lel, Say on Pay Laws, Executive Compensation, Pay Slice, and Firm Value Around the World 2-3 (Apr. 2014), available at http://papers.ssrn.com/sol3/papers.cfm? abstract_id=2243921 (unpublished manuscript).

337. Id. at 2-3. Correa and Lel also find that Say on Pay laws are associated with lower levels of executive compensation, higher pay for performance sensitivity, and lower pay inequality between top 


\section{d. Impact of Say on Pay Votes on Executive Compensation}

In the United States, Say on Pay has not led to lower executive pay levels or changes in its composition. While some proxy advisory firms recommended that Say on Pay proposals be evaluated, in part to determine whether inappropriate peer group "benchmarking" had led to the upward spiral of executive pay, ${ }^{338}$ shareholders seem to have largely ignored the suggestion. ${ }^{339}$ Prior research finds that Say on Pay had little or no impact on executive compensation levels. ${ }^{340}$ In the U.S., this trend continued into the 2013 proxy season. ${ }^{341}$ Research in the U.K. has also found that overall CEO pay levels do not seem to have changed as a result of Say on Pay votes. $^{342}$

However, Correa and Lel find that pay growth rates are lower in their comparative study of eleven countries that have adopted Say on Pay legislation. ${ }^{343}$ Their cross-country study of thirty-eight nations-eleven that have adopted Say on Pay and twenty-seven that have not done so-finds that although "CEO compensation has increased in several [Say on Pay]

managers. Id.

338. Gretchen Morgenson, If Shareholders Say "Enough Already," the Board May Listen, N.Y. TIMES (Apr. 6, 2013), http://www.nytimes.com/2013/04/07/business/shareholders-can-slow-theexecutive-pay-express.html (reporting that use of peer group benchmarking seems to contribute "mightily" to growth of CEO pay by creating an "arms race in pay"). For further discussion of the effect of peer group benchmarking on CEO pay levels and composition, see also John M. Bizjak, Michael L. Lemmon \& Lalitha Naveen, Does the Use of Peer Groups Contribute to Higher Pay and Less Efficient Compensation?, 90 J. FIN. ECON. 152, 166-67 (2008) (examining "the extent to which the use of peer groups and competitive benchmarking process affects compensation," and finding that "the use of peer groups is pervasive," and that this practice has "a nontrivial effect on the changes in pay of the CEO") and Charles M. Elson \& Craig K. Ferrere, Executive Superstars, Peer Groups, and Overcompensation: Cause, Effect, and Solution, 38 J. CORP. L. 487, 495-500 (2013) (describing the peer benchmarking process and the problem with peer group analysis).

339. See Thomas, Palmiter \& Cotter, supra note 4, at 1257 ("One thing that did not happen during the 2011 proxy season, however, was a shareholder backlash at increasing levels of executive pay.").

340. Cuñat et al., Say Pays!, supra note 14, at 5. Compare Iliev \& Vitanova, supra note 333, at 3 (finding that the introduction of Say on Pay votes increased the level of CEO pay by 14 percent).

341. Jesse Eisinger, In Shareholder Say-on-Pay Votes, More Whispers Than Shouts, N.Y. TIMES (June 26, 2013, 12:00 PM), http://dealbook.nytimes.com/2013/06/26/in-shareholder-say-on-pay-votesmore-whispers-than-shouts/ (reporting that executive pay levels continue to rise steadily even after the implementation of Say on Pay). See also Gretchen Morgenson, An Unstoppable Climb in C.E.O. Pay, N.Y. TIMES (June 29, 2013), http://www.nytimes.com/2013/06/30/business/an-unstoppable-climb-inceo-pay.html (reporting that CEOs received a 16 percent median pay increase in 2012 over 2011 pay levels).

342. Martin Conyon \& Graham Sadler, Shareholder Voting and Directors' Remuneration Report Legislation: Say on Pay in the U.K., 18 CORP. GoV.: INT'L REV. 296, 297 (2010) (finding no change in the overall level of executive pay or its rate of growth subsequent to Say on Pay votes). See also Ferri \& Maber, supra note 315 , at 555 (finding that firms did adjust contractual features and increase sensitivity to pay for performance in response to negative vote outcomes).

343. Correa \& Lel, supra note 336 , at 15. 
countries including the United States and United Kingdom, the growth in CEO pay is higher in countries that have not passed [Say on Pay] laws." 344 If their results are correct, it is hard to know whether the relative decline in CEO pay levels reflects additional leverage for directors in negotiations with CEOs or greater willingness of directors to stand up to CEOs because of their fear of losing their jobs. These relative declines in executive compensation levels may lead to improvements in firm value if they result in more money going into shareholders' pockets.

\section{e. Say on Pay's Effect on Corporate Governance}

Say on Pay's introduction had a significant effect on American corporate governance. ${ }^{345}$ Dodd-Frank's mandated shareholder votes focused directors on shareholders' concerns about executive pay, increased shareholder participation in corporate governance, and opened lines of communication between management and shareholders (and proxy advisory firms) regarding executive compensation. ${ }^{346}$ Beginning with the U.S. experience, management at many companies made changes to the substance and disclosure of their pay programs in an attempt to more clearly align pay to performance. ${ }^{347}$ Many companies revised the content of the compensation discussion and analysis filed with the annual meeting proxy materials, while management at other companies whose pay programs received negative Say on Pay recommendations by proxy advisory firms connected with shareholders following an "against" recommendation. ${ }^{348}$

At some companies, management is becoming more responsive to negative shareholder votes on pay policies. ${ }^{349}$ For example, in 2013, Infinera Corp., Hercules Offshore, Inc., and Chesapeake Energy responded to failed Say on Pay votes by changing pay programs to eliminate perceived poor pay practices and by improving proxy disclosures. ${ }^{350}$ Such

344. Id. Figure 1 in Correa and Lel's study illustrates the gap between the two groups of countries. Id. at 35 .

345. See Thomas, Palmiter \& Cotter, supra note 4, at 1256.

346. Luis A. Aguilar, Comm'r, U.S. Sec. \& Exch. Comm'n, Speech by SEC Commissioner: An Inflection Point: The SEC and the Current Financial Reform Landscape at the Social Investment Forum 2011 Conference (June 10, 2011), available at http://www.sec.gov/news/speech/2011/ spch061011laa.htm.

347. Michael LitTenberg, Farzad Damania \& Justin Neidig, CONFERENCE BD., Director Notes: A Closer LOOK AT NEgATIVE SAY-ON-PAY Votes DURING THE 2011 Proxy SEASON 2 (July 2011), available at http:/www.srz.com/A-Closer-Look-at-Negative-Say-on-Pay-Votes-During-the2011-Proxy-Season-07-26-2011/.

348. Cotter, Palmiter \& Thomas, supra note 310 , at 994, 998-1001.

349. Thomas, Palmiter \& Cotter, supra note 4, at 1260.

350. Hughes, supra note 320. 
actions frequently result in significantly more shareholder support for the revised pay policies in the following year. However, unless these changes are tied to improvements in long-run firm value, they would not support having a shareholder vote on executive compensation.

\section{f. Summary}

The empirical evidence summarized above supports the general claim that Say on Pay votes improve firm value, reduce relative levels of executive compensation, and improve corporate governance, ${ }^{351}$ although there is one study that finds small negative market reactions to changes in compensation policies implemented prior to the first Say on Pay vote. ${ }^{352}$ Under our theory, if Say on Pay leads to increases in firm value, such a result would support having these votes to monitor firm executive compensation practices. Excess managerial compensation is an indicator that the board of directors of the company is overpaying the company's CEO compared to the level of expected pay for a company with its characteristics, and may indicate weak corporate governance at the firm. Similarly, persistent poor relative performance, usually measured by a three-year total average shareholder return comparison with peer firms, may indicate bad management, and therefore a weakness in the board of directors' oversight of the CEO, or poor alignment of pay and performance at the firm. A failed Say on Pay vote will signal to the board of directors that they need to pay more attention to these issues, and may even signal to hedge funds that the firm is a good target. ${ }^{353}$

\section{CONCLUSION}

Theoretical and real world developments have rendered existing theories of corporate voting outdated and inaccurate. This Article develops a new theoretical model for shareholder voting that takes these important changes into account. We argue that shareholders, and only shareholders, should have the vote, and that they should be asked to vote in a number of different settings. While this view is subject to several important criticisms, we show government intervention has provided shareholders with incentives to vote, and that institutions facing significant conflicts of

351. Cuñat et al., Say Pays!, supra note 14, at 4-6; Iliev \& Vitanova, supra note 333, at 2-3; Cai \& Walking, supra note 335, at 334-35.

352. Larcker, McCall \& Ormazabal, supra note 326, at 40.

353. "An intriguing consequence of a failed [Say on Pay] vote is that, while shareholders may be attempting to signal their displeasure with the CEO and the compensation committee, the failure may have repercussions well beyond CEO compensation." KRAUSE, WHITLER \& SEMANDI, supra note 320, at 5 . 
interest in voting can adopt policies to remedy those problems. Finally, we apply our theory in two critical contemporary settings-hedge fund activism and Say on Pay-to demonstrate why shareholder voting should be required in both of them. 